Historic, Archive Document

Do not assume content reflects current scientific knowledge, policies, or practices. 


\section{Annual Catalog of}
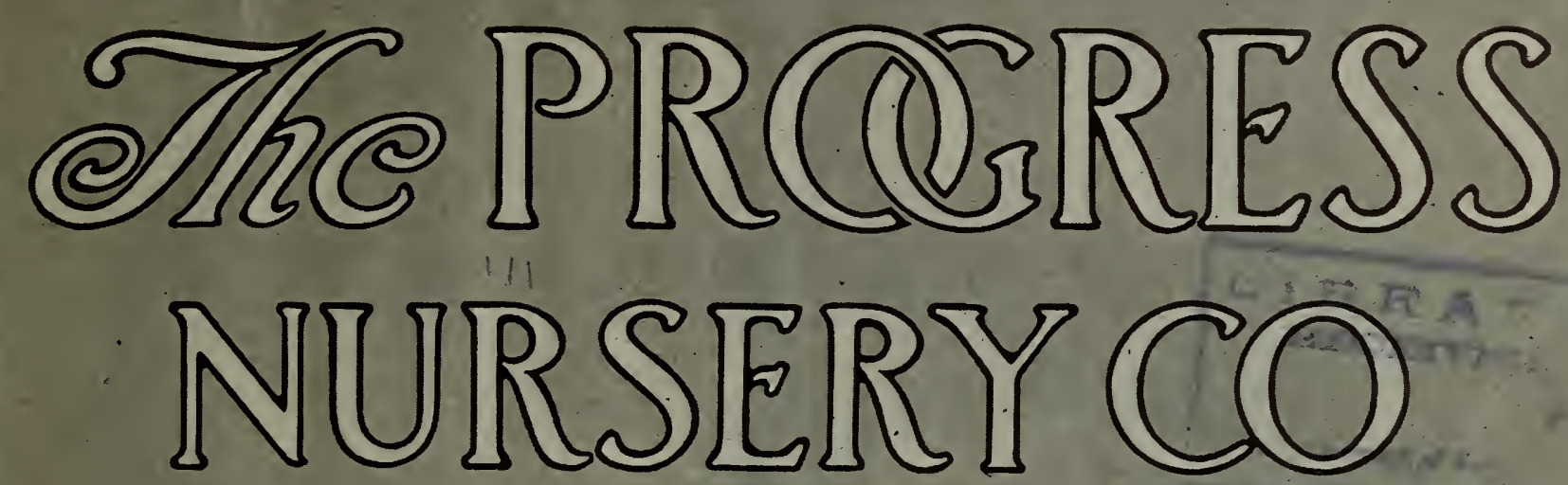

\section{Troy.}
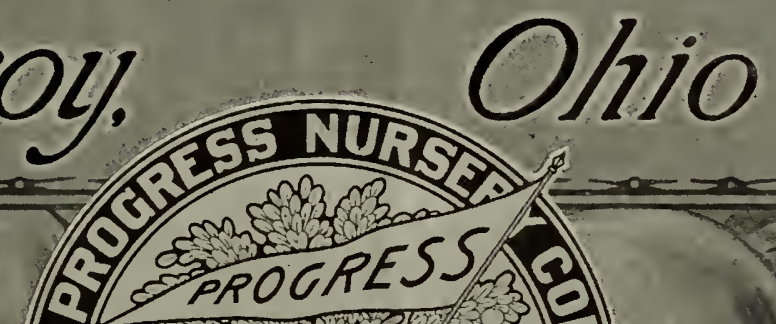

(5) NUDAR:

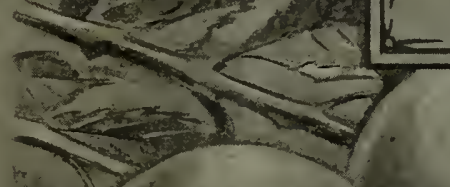

SPROCRESS
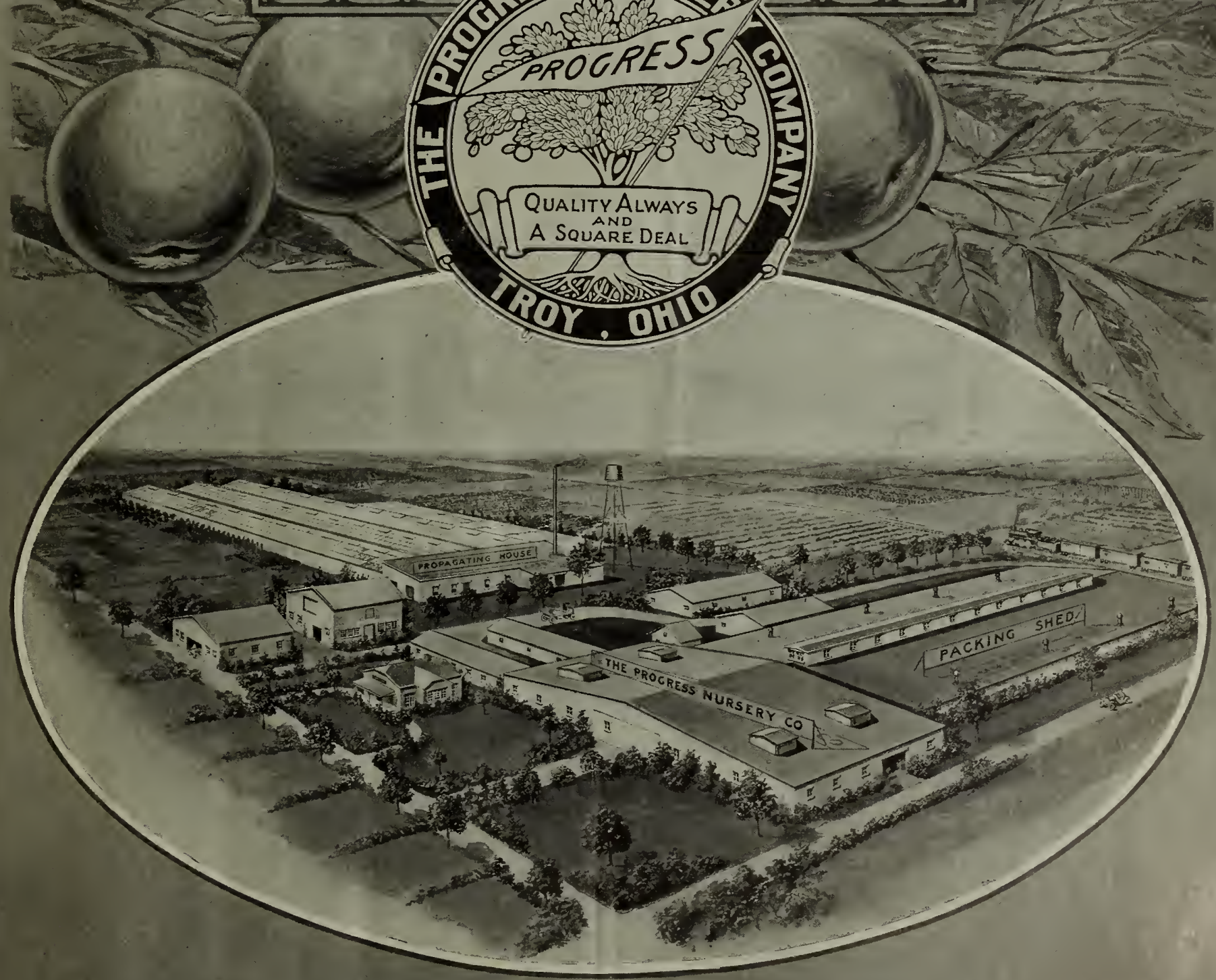

BirdseyeView Progress Nursery CO. 



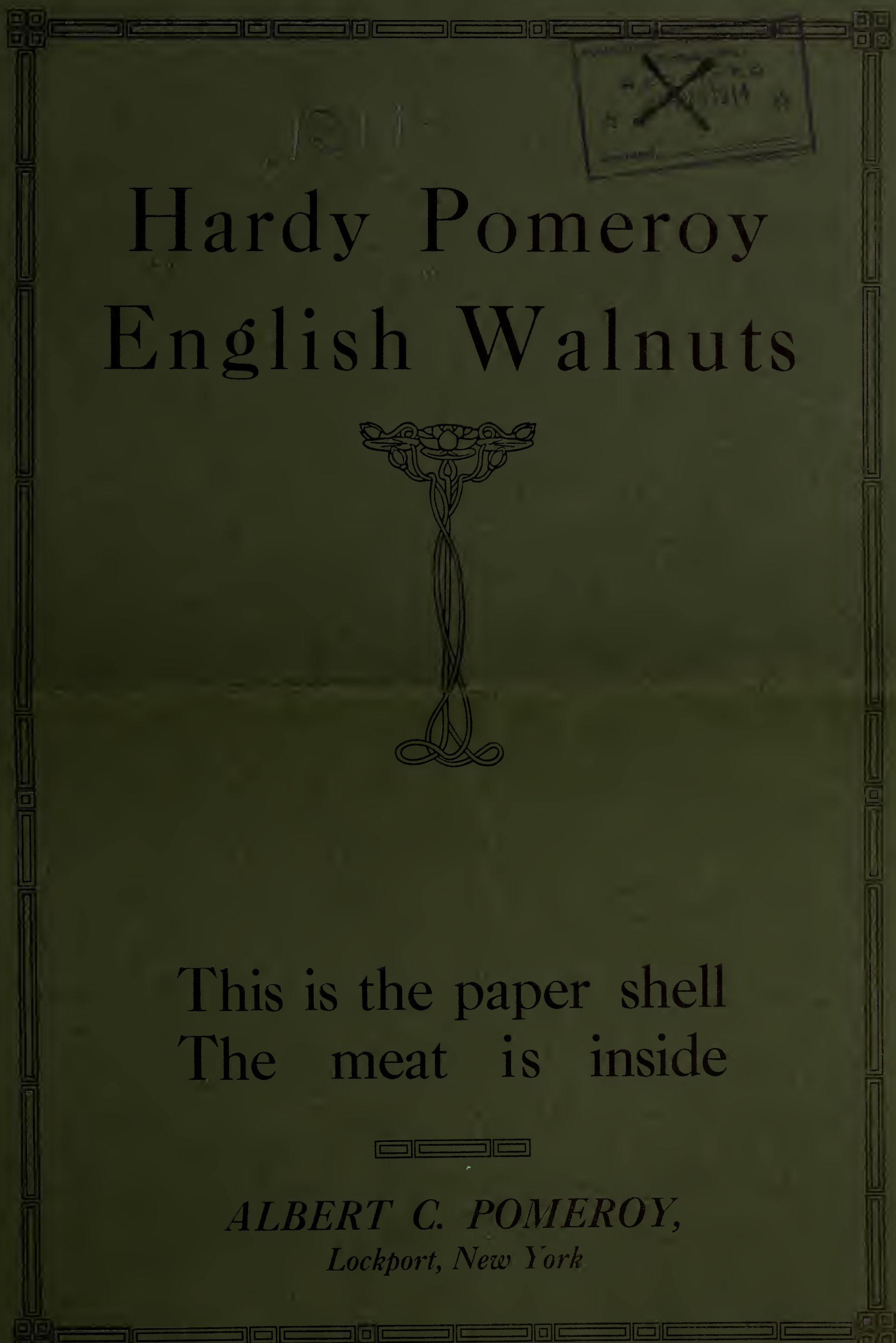




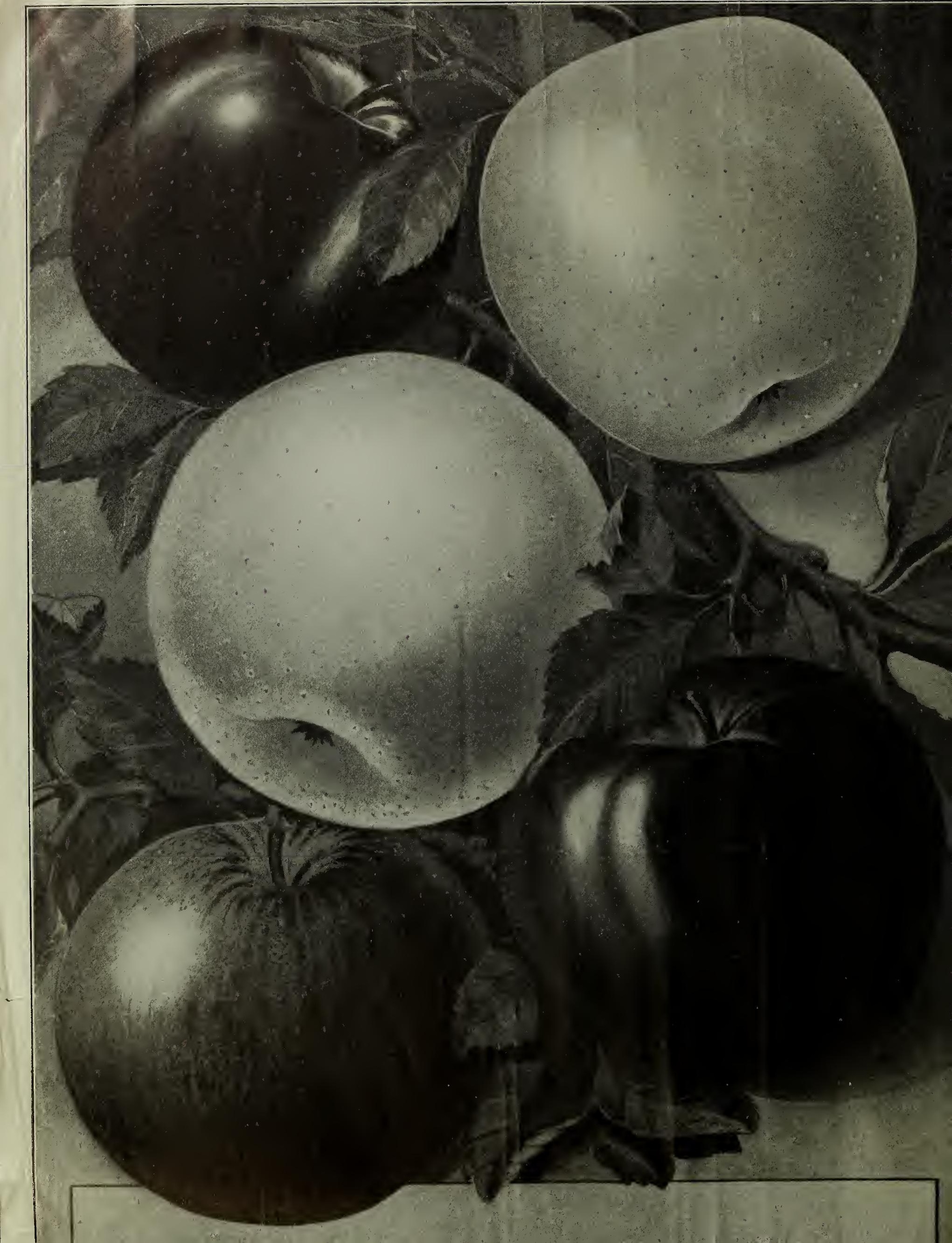




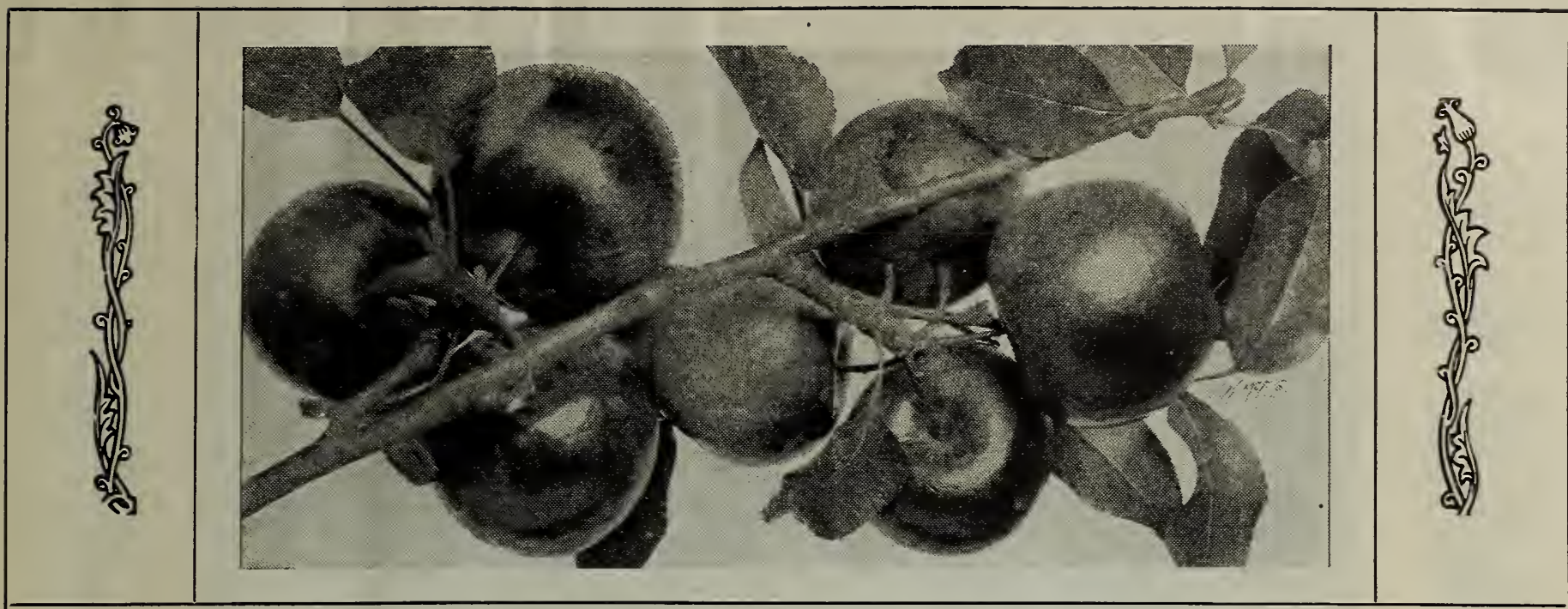

\section{The Progress Way-Direct To You}

\section{THE RECOGNIZED AND MOST ECONOMICAL WAY FOR YOU TO BUY NURSERY STOCK IS DIRECT FROM THE NURSERY. THIS IS A PROVEN FACT}

It's so easy. The reasons are so practical, and the final results so satisfactory, that, when once you buy from us direct, you will always be a "Progress Booster" and a permanent Progress customer. That's the reason in a nutshell for our success today. It's the neighbor-to-neighbor and friend-to-friend advertising that we have had in the past that has developed our business to its present position. It's the "Quality Always and a Square Deal" policy of the Progress Nursery that's winning out.

The above gives you in just a few sentences, and a straight-from-the-shoulder statement, why we became a "Directto-You Nursery," and why we are going to continue the same policy.

Our Annual Catalogue (our only salesman) is before you. It describes all valuable varieties of fruit trees, vines, shrubs and ornamental trees.

We catalogue and handle only the kind of stock we believe in, and from experience has proved to be just as represented. We request that you note especially our remarkably low prices, bearing in mind that all this stock is sold under our guarantee of quality, and to be absolutely true to name.

\section{The Progress Nursery Company Employs No Agents}

We sell direct to you. Do you realize what a saving this means to you, and how important it is to us to give you full value on every order? It puts you right in touch with the man who should be responsible for what he ships you. Simple transaction, isn't it? Just you and The Progress Nursery Company.

If you could visit our nurseries, during shipping time, you would find the head of our organization right there, where he should be, supervising and inspecting every shipment as it goes out.

Whether it's an order for one tree or a thousand, it's the same story from the very beginning of each tree and plant. We know the life-history of every tree and plant we sell, because we grow them in our own nurseries. We dig haul, and pack every tree and plant under the same personal supervision which the final shipment has.

When you order from this catalogue, you get exactly what your order calls for, because we make it a personal matter.

We are not satisfied with the order you are sending us today-it's your future orders we want.

We know there's only one way to get them, and that's why our motto is

\section{A Final Word:}

\section{"Quality Always and a Square Deal"}

We are open to any matter you would care to consult us about regarding tree- and plant-life.

We maintain a special Information Bureau for this purpose. Your letters will be answered promptly.

We want your order. Give us a chance to prove our claims, and help you make your orchard or garden a big success.

\section{THE PROGRESS NURSERY GOMPANY, TROY, OHIO}



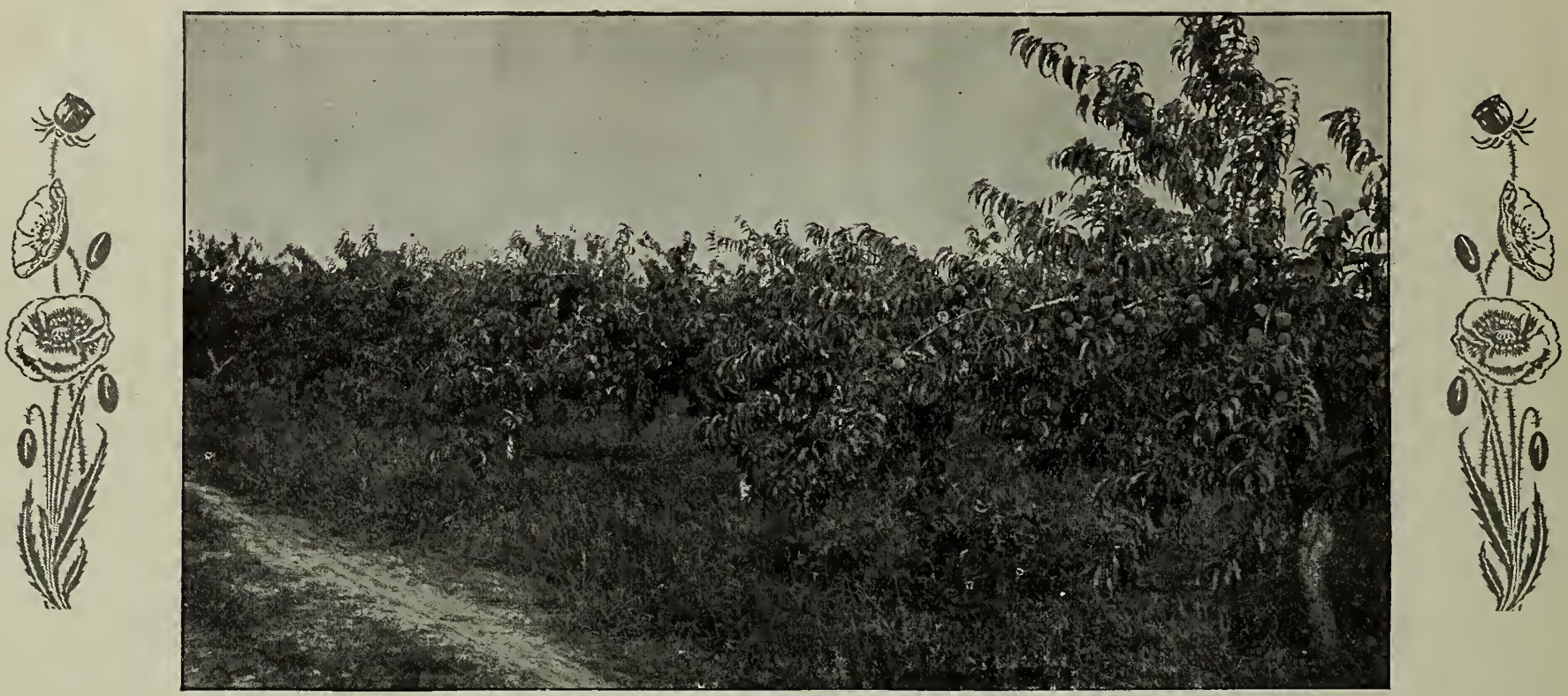

Results like this can be obtained by planting our trees

\section{Examination of Trees}

Immediately upon receiving your trees open the bale or box in which they have been shipped, and check up your order to see that it is all there. As we are only human, we occasionally make mistakes. But we always hold ourselves in readiness to rectify all such mistakes, if brought to our attention immediately.

To many people a tree is just a tree, and one young tree is expected to look just like every other one, while, as a matter of fact, there is as much difference in the growth and appearance of different varieties of Apple trees, for instance, as there is in the different breeds of horses and cattle.

The man who does not know trees will look his order over, and then say, "Well, the Grimes 'Golden Apples and Kieffer Pears and Sweet Cherries are fine; but just look at the Fameuse Appleslittle, stunted things that no one would want as a gift, and the
Duchess Apples are not much better, while the Seckel Pear trees are fully 2 feet shorter than the Kieffers." He immediately concludes that the nurseryman has filled his order out of stock which should have gone to the brush-pile. The very man who thought this way about his trees could, no doubt, point out to you all the good qualities of the raw-boned, crooked-legged colt that he has running in his barn lot. Experience has taught him that those bones will take on sinewy muscles, and that those crooked legs will finally straighten up. It is exactly the same way with many of the best varieties of fruit. During their first few years of growth they are crooked and misshapen, but, as they grow older, they straighten up, and finally become as shapely and fine-looking trees as the Grimes Golden, for instance, which pleased the planter so well in the first place.

\section{Hints on Transplanting}

Every man who buys a bill of nursery stock should know how to handle his trees upon securing them, and how to prepare the soil and how to plant them. We are, therefore, inserting a few hints which, if followed, will not only help him, but crown his efforts with success. One cannot be too careful in handling his trees when received.

Immediate Care. Immediately upon receiving your trees, heel them in, putting mellow earth around the roots. An hour's exposure of the roots to the sun is sure death to some trees. If they appear, upon opening the bale, to be dried out, bury the whole tree in moist earth for a day or two.

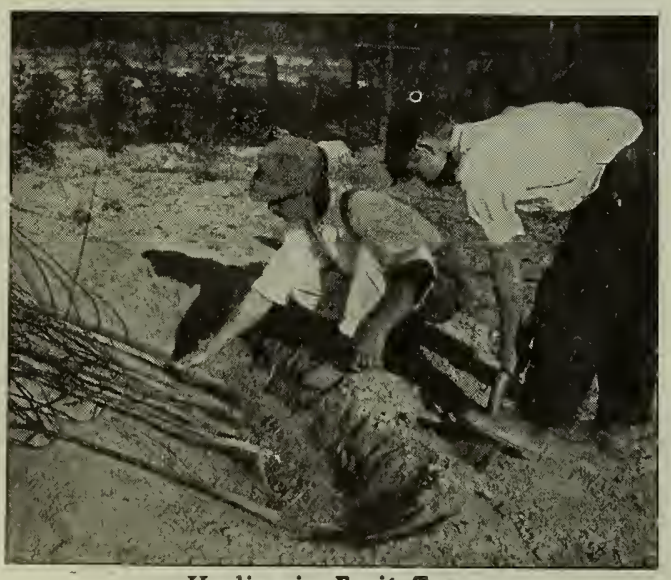

Heeling-in Fruit Trees
Preparation of the Soil. All land intended for orchards should be well drained. Good fruit cannot be grown in wet soil. To insure a good growth of fruit trees, the land should be rich enough to raise a crop of wheat, corn or potatoes. On new land fertilizers will not be necessary, but on land exhausted by other crops it is very essential that you should either plow under a good, heavy crop of clover or other leguminous crop, or well-decomposed manure or other compost.

In planting large orchards the subsoil plow should be used in connection with a common breaking plow. Dynamite is also becoming very popular as a subsoil agency.

Planting. After the ground is well prepared, dig the holes large enough to admit the roots of the tree in their natural position, and also deeper than necessary, so that the loose surface soil can be shoveled into the hole, and packed solidly in the bottom. No matter how careful the nurseryman is in digging trees some roots will be bruised. Cut off all such bruised or broken roots, up to the solid wood, with a sharp knife, making a slanting cut. A clean cut heals sooner than a bruise. See to it that all roots are in their natural position when the tree is placed in the hole, shovel in only a little soil at a time, and press it firmly about the roots. After the hole is almost full it is advisable, in dry weather, to pour a pail of water into it. Let this soak away, and then finish filling it with soil.

Do not plant trees too deep. They should stand about as they did in the nursery row. Dwarf Pears should be planted 3 to 4 inches deeper. 
HINTS ON TRANSPLANTING, continued

Pruning. Trim up the tree to four or five branches, suitable for forming a top, cutting each of the side branches back to 4 or $\vec{j}$ inches from the body of the tree, leaving the leader or center shoot 8 to ro inches long. One-year trees should be trimmed up to a straight whip, and headed at about 28 inches from the ground.

To insure yourself against loss, if the first season after planting should prove to be dry, mulching is advisable. Throw about the tree and a foot beyond the roots about 4 or 5 inches of rough manure or litter. This holds the moisture, prevents the ground from baking or cracking, and maintains an even temperature about the roots.

After Culture. Never allow grass to grow about young trees. The ground should be kept loose about them until they are of bearing age. We advise the planting of a cultivated crop in all young orchards. This insures your keeping the ground well broken up, and consequently more growth in a shorter number of years. The

\section{Terms and Conditions}

We do not and will not employ agents. There are no middlemen to pay when buying of us.

Cash must accompany orders, because this eliminates loss and credit accounting, and enables us to give lower prices and
better values.

Make remittances by Money Order, Bank Draft or Registered Letter. Customers sending money in letters without registering do so at their own risk.

C. O. D. Orders. If customers wanting large orders will send satisfactory references, with one-fourth of the purchase price, goods will be shipped, with privilege of examination before accepting or paying the remaining three-fourths. This plan insures us getting our pay if we send the right kind of stock, and insures the customer getting just what he ordered before paying his money. If you do not find trees up to standard, we will refund the money paid on them. See how many other nursery firms will do this.

Five trees will be furnished at ro rates, 25 at the roo rates and 250 at the 1,000 rates, except in the case of special quotations. Stock that does not grow under proper treatment, will be replaced at one-half catalogue prices. On large box orders we are able to make special prices.

We have fine shipping facilities for sending goods east, west, north or south, which insures you against the danger of serious delays that occur where there is but one railroad and one express company. Troy has four railroads and three express companies. Always give explicit directions about shipping. When no instructions are given, we use our best judgment as to the mode of sending out orders. As we ship many trees and plants each year, we are thoroughly competent to do this.

It isn't always possible for the man who desires to plant to know just what varieties he wants. A variety may be of superior quality in one locality, and almost worthless in another. For a good many years we have studied Experiment Station Reports, Government Bulletins, and, above all, reports of individual growers all over the country, as they appear in the farm and fruit journals. We can tell, therefore, with a fair degree of certainty, what varieties do best in each section for home or commercial planting. We shall be extremely glad to share this information with all who wish it.

When so desired, we make selection of the different kinds of fruits or trees wanted, giving an assortment of early, medium and late kinds. This will apply especially to Apples, Peaches and Strawberries. We are always glad to take such matters up with

quicker a tree reaches matu
the profits of your labor.

Spraying. We would advise all our patrons to communicate with their State Experiment Station, and get definite instructions about spraying for their own locality. For instructions about mixing spraying material, see our Spray Calendar on page $3 \mathbf{I}$.

\section{Treatment of Trees Received in Freezing Weather}

Place the package, unopened, in the cellar or some other such place where it is cool, but free from frost, until the trees are perfectly thawed out. This usually takes about ten days. Then they can be unpacked and either planted or placed in a trench convenient for planting. If so treated the freezing will not hurt them.

those who are thinking of planting commercial orchards, and believe that they will find our help very beneficial.

The growing of fruit is increasing year by year, and it has become a very profitable industry for those who exercise care in the selection of varieties, and give the proper attention to cultivation, pruning and spraying.

Certificate of Inspection. Our grounds are annually inspected by the State Inspector, and all stock is again examined by him before shipments are made, and each one carries with it a certificate from him that there are no dangerous insects or contagious diseases of fruit trees on them.

\section{Progress Business Methods}

Our one aim is to give the planter the very best trees that can be grown; trees that will please him. One chance is all we ask. Give our trees a trial, and we know that you will be satisfied. Each order, no matter what the size, is given the same careful attention by the head of our packing and shipping department. He goes over each one to see that every article is just what it should be.

Order early, while our stock is still full. It is often impossible to procure varieties wanted for late orders. We fill orders consecutively, just as they come in. You can readily see the advantage of the early orders. When spring planting is preferred, we will book orders in the fall and hold stock wanted, ready for shipment when desired. In ordering, write the name, number and size of each variety plainly so as to avoid mistakes. In filling orders we reserve the right, in case we are out of the variety wanted, to substitute another of equal merit, when it can be done, always labeling with the correct name, unless the purchaser writes "no substituting" on the order. In case we are unable to fill an order, we will just as cheerfully refund your money as we receive it.

\section{Progress Guarantee}

We guarantee our customers against wilful or intentional substitution or change of labels, and at all times exercise the greatest care to have every variety exactly what it purports to be. But beyond this we can assume no responsibility as to varieties. The very nature of the nursery and seed business makes it impossible to give an absolute guarantee. However, if any tree, when it comes to maturity, proves to be untrue to label, we will either replace it or refund purchase price. Beyond this we can assume no responsibility.

\section{Premiums We are Offering for Early Ordering}

All orders received before March, accompanied with cash, amounting to $\$ 2.50$ or more, will contain a premium according to size of order. Each order amounting to from $\$ 2.50$ to $\$ 5$ will contain one Montmorency Cherry tree. Each order amounting to from \$5 to \$ro will contain one Grimes Golden Apple tree and a two-year-old field-grown Concord Grape-vine. Each order amounting to from \$IO to \$I5 will contain one Grimes Golden Apple tree, one Baldwin Cherry tree and one Elberta Peach tree.
Except in the case of special quotations, we will pay the transportation charges on all orders amounting to \$I 5 or more. Each will contain a premium according to its size.

In addition to the above-named premiums, we will send with all orders amounting to $\$ 5$ or more, reaching us before April I, one of those famous new Lowry Apple trees, the Apple which is creating so much talk in the Apple-growing districts of Virginia. For full description of the fruit, see page 6. 


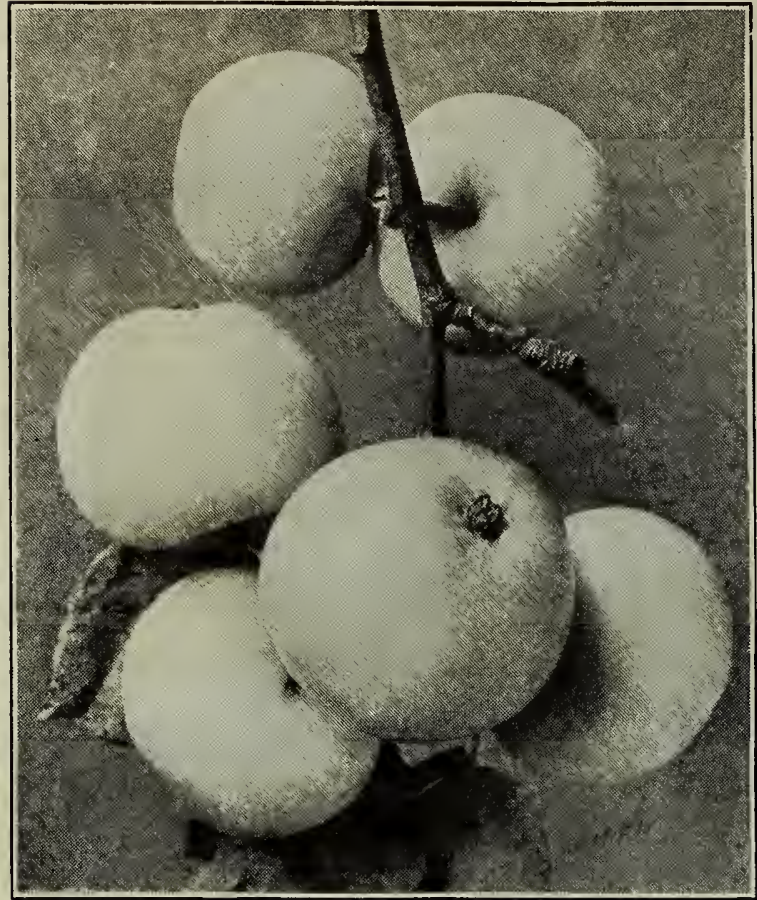

Yellow Transparent Apples

\section{APPLES}

Are you contemplating planting an Apple Orchard? If you are, you cannot find anyone that will take a more personal interest in your planting than we. Nor does our interest stop when you purchase the trees. There is nothing that pleases us more than to hear from as many as possible of our large list of friends, each year, with reports as to how their trees and plants are doing. Often a few hints from us will be of great assistance to the orchardman.

One of the strongest features of our nurseries is the great care that we take to select our parent trees from which to get our scions. Our trees are propagated from such trees as those of Reed and Fielding, of Glenwood, Indiana, whose exhibit of fruit took the majority of prizes, as well as sweepstakes, at the Indianapolis Apple Show in ror2. We have spent considerable time and money to secure the strains of the different varieties that they grow, even going to their orchards in person and selecting the trees from which our buds were cut.

Our Rome Beauty, as well as several others of our leading varieties, comes direct from the U. T. Cox orchards at Proctorville, Ohio. Mr. Cox claims that his strain of Rome Beauty is unsurpassable

We tell you this that you may see that we are ever on the alert, watching for improved strains of the leading varieties.

We advise all planters who are setting out trees for their individual use to plant two-year-olds. The tops of these have already been trained by experts in tree culture. However the commercial orchard planter, as a general thing, has ideas of his own as to how he wants his tree-heads formed. To him we would say that we have as fine a lot of one-year-olds as can be found, and are able to supply all leading varieties.

\section{SUMMER APPLES}

Red Astrachan. Large, roundish; nearly covered with deep crimson, overspread with thick bloom; juicy; tender, somewhat tart. Valued as one of the most beautiful early market and dessert apples, very hardy and a good bearer. Generally begins bearing fruit the third year after planting, and bears regular crops. July.

Early Harvest. Medium to large, pale yellow, sometimes with faint blush; tender and subacid. Ripens in July, but may be used for cooking earlier. Tree erect, moderate in growth, but quite productive.

Golden Sweet. Large; golden yellow; tender and crisp. One of the very best sweet Apples. Forms a vigorous, spreading, fruitful tree. Ripens in August.

Sweet Bough. An excellent sweet Apple for the market. Pale yellow; very sweet and tender; large and unsurpassed for baking. A compact grower and abundant bearer, yielding large crops annually. August.

Tetofsky. A fine summer market Apple of medium size; yellow ground, handsomely striped with red; agreeable; better for cooking than dessert. A stocky grower; very hardy and productive, bearing its fine-flavored fruit regularly. July and August.

Yellow Transparent. Often begins to bear the first season after transplanting, sometimes bearing while still in the nursery row. We cannot say too much for this Apple; it is probably the most extensively planted summer variety from the Atlantic to the Pacific, being very productive in any climate. Its Russian origin makes it one of the hardiest Apples known; an excellent grower and enormously productive. Fruit medium to large, roundish, slightly conical; pale yellow when fully matured; tender, juicy, slightly acid. Begins ripening about the middle of July and often continues until the middle of August.

\section{AUTUMN APPLES}

Chenango. Tree hardy and long-lived; highly valued as a table or market iruit; medium to large in size, oblong; yellowish white, striped with bright red, very handsome. August to September.

Dr. Watson. Above medium size; yellow, washed with red and brokenly striped with dark crimson; flesh yellowish, fine, tender, juicy, subacid. An excellent Apple for the home orchard and local market.

Fall Pippin. Tree is hardy and long-lived, growing to great size. One of the most desirable varieties of its season for the home orchard and a good keeper. Large and, when fully ripe, a beautiful yellow; flesh is tender, rich and of good quality for dessert and cooking. Season September to December. May be held in storage until February.

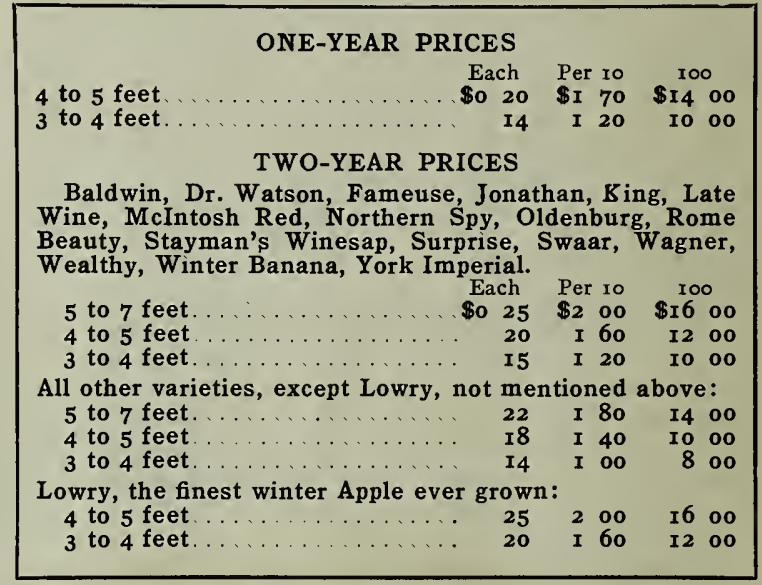

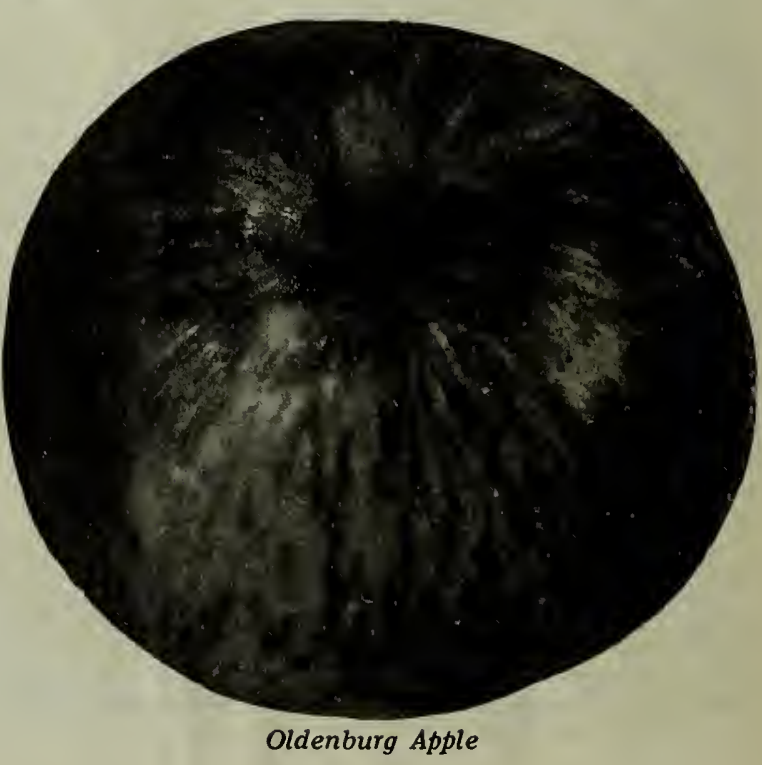




\section{AUTUMN APPLES, continued}

Fameuse (Snow). Little need be said about this well-known market sort, especially to the northern fruit-growers. An Apple that always sells above the average market price in its season. Tree moderate grower, hardy, very healthy, long-lived and a most reliable cropper; fruit deep crimson; flesh snowy white, tender, melting, delicious. October to January.

Late Wine. Medium size, roundish; shaded with light and dark crimson; flesh white, very tender, juicy, mild, pleasant subacid, very good. Tree an upright, vigorous grower and an early and abundant bearer. October and November.

Longfield. A very large, hardy Russian Apple; vigorous, spreading, pendulous growth, early and annual bearer. Fruit roundish, conical, unequaled in size, slightly blushed; flesh very white, tender and juicy, pleasant, brisk subacid; surface smooth, polished, clear, waxen white. October and November.

Maiden Blush. A good market sort because of its attractiveness and heavy crops. Tree a vigorous grower, with spreading, open top. Fruit medium size, smooth, round, beautifully flushed with red on creamy yellow ground; flesh tender, of pleasant flavor. One of the best for cooking. A favorite wherever grown. September to October.

Oldenburg (Duchess of Oldenburg). Large, roundish; pale yellow, almost covered with irregular splashes and stripes of bright red, mottled and shaded with crimson, very attractive in appearance; tender, juicy and pleasant. A kitchen Apple of the best quality and esteemed by many for dessert. A fine grower, a young and abundant bearer. Very hardy, moderately long-lived and a fne cropper; succeeds well in the Northwest, where most other varieties fail. Season August to September.

Rambo. A pretty red-and-yellow Apple of medium size and good flavor; widely cultivated and everywhere esteemed. The tree is a strong grower and a heavy bearer. October to December.

Swaar. Large, roundish; greenish yellow with russet markings, slightly blushed; flesh yellow, juicy, subacid, rich; of excellent quality. One of the fine old dessert Apples and highly deserving of cultivation. November to December.

Western Beauty (Summer Rambo). One of the most desirable sorts for home and market. Large to very large; pale yellow, brightly splashed with red; the light yellow flesh is tender, juicy and melting. October.

Wealthy. A red Apple of superior merit. Tree is one of the hardiest and most prolific. Fruit medium, roundish; skin smooth, oily, mostly covered with dark red; flesh white. fine, juicy, vinous, subacid, very good. October.

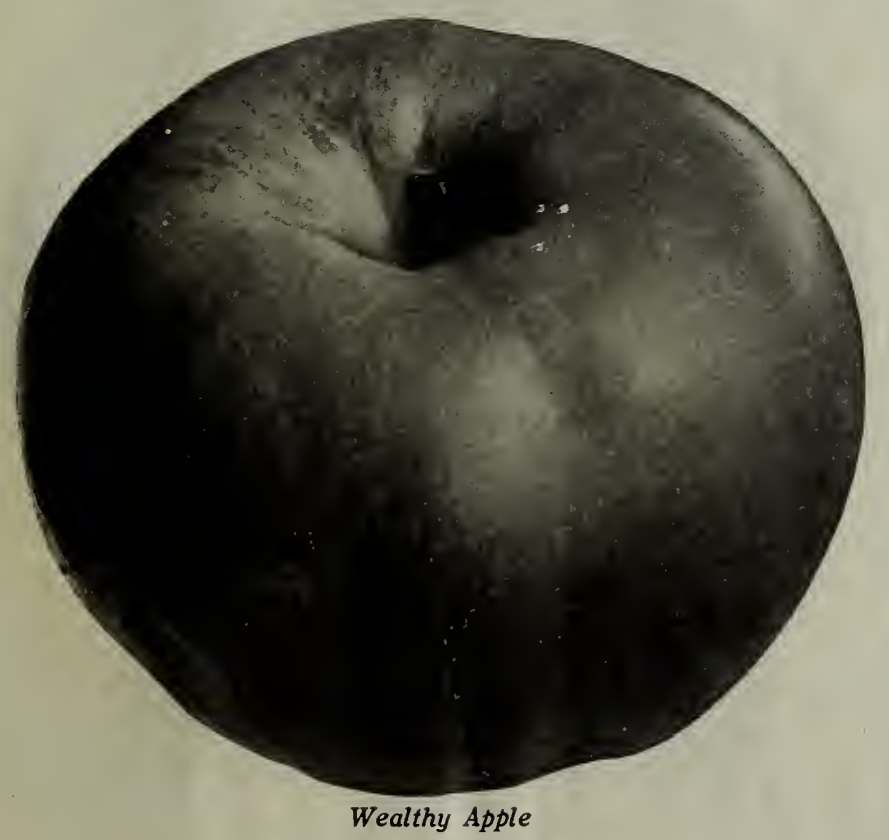

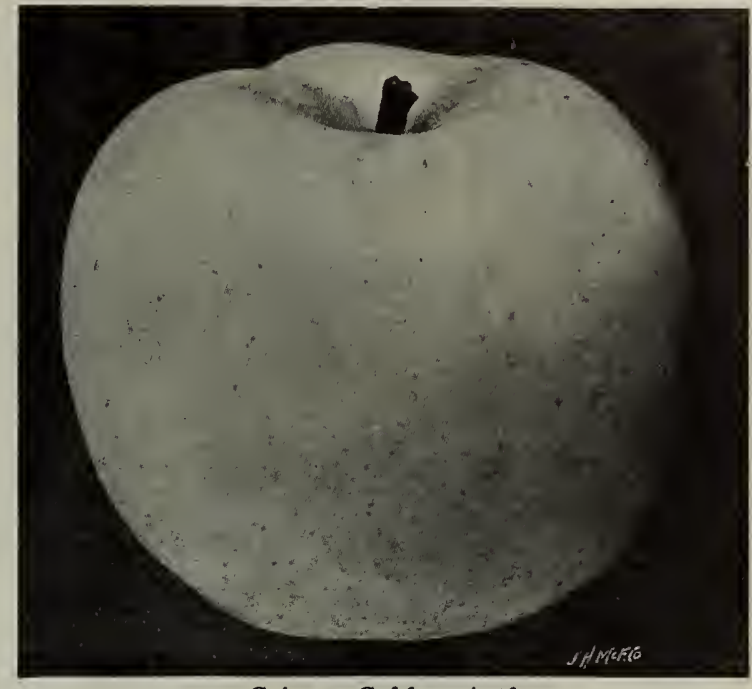

Grimes Golden Apple

\section{WINTER APPLES}

Arkansas Black. One of the most beautiful of Apples, being a remarkably large and handsome crimson-black, lightly dotted with white; takes on a very high polish, perfectly smooth, roundish, flat; the flesh is yellow, juicy and delicious, and it is one of the best keepers. The commercial orchard planter does well to include some of this variety in his orchard, as it is one of the best moneymakers. December to April.

Akin. A strikingly beautiful red winter Apple, especially adapted for dessert use and fancy market trade. Fruit medium in size, of very best quality, with tender, juicy flesh, slightly tinged with yellow; very aromatic. Tree hardy, healthy and reliably productive.

Baldwin. One of the most popular and profitable sorts for either table or market, because of its desirable season, good size, color and quality. It is especially a leader in the North for both home and foreign market. Another good quality is the uniformity of size of the trees. Strong grower and noted for its longevity. Fruit large, roundish; deep red; crisp, juicy flesh. December to March.

Ben Davis. Origin, Kentucky. Vies with Baldwin as a profitable commercial Apple in many sections; one of the best bearers and keepers. Tree very vigorous and hardy in the central states. Fruit large, handsome, brightly striped with red; flesh medium quality. January to April.

Dominie (Winter Rambo). Tree a profuse bearer and quite vigorous and hardy. A large, flat Apple of good size, with light yellow skin heavily striped and splashed with red; flesh tender, pleasantly perfumed. November to April.

Fallawater (Tulpehocken). Large and handsome, with smooth skin of a yellowish green, with dull red cheek; flesh is greenish white, fine-grained and juicy. Tree grows fast and bears young and heavily. November to March.

Gano. Very attractive in appearance, stands handling well and is a good keeper. Of the Ben Davis type, although much better in quality. The tree comes into bearing young and is an excellent cropper, bearing regularly and abundantly. Especially adapted to the central states. We recommend this variety very highly as a commercial Apple, not so much for its quality, which is only fair, but for its high, rich red color, and because of its being an almost annual cropper. When properly packed it always brings the highest market prices.

Grimes Golden. Skin yellow, sprinkled with gray dots; crisp, juicy, tender; one of the best if not the best yellow Apple now grown. Its value for both home and commercial planting is well known, as it is eagerly sought for in market and invariably brings top-notch prices. A good bearer, and grown extensively in the central states. November to January. 


\section{THE PROGRESS NURSERY COMPANY, TROY, OHIO}

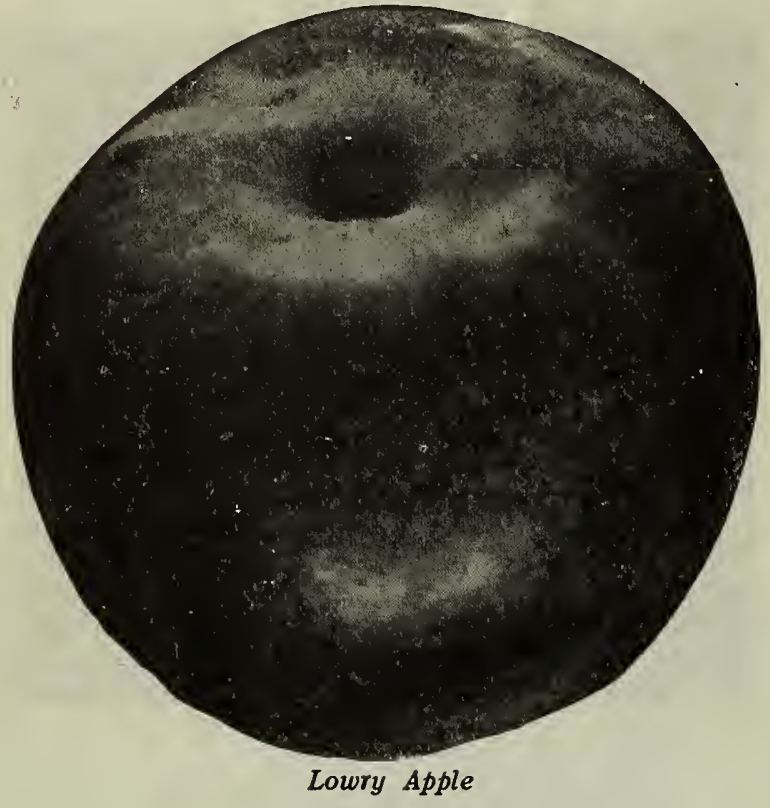

WINTER APPLES, continued

Hubbardston. A very popular sort for both home and commercial planting. Tree very robust and regular in bearing heavy crops, which begin when the tree is very young; fruit large to very large; attractive red mingled with yellow; flesh crisp, juicy, rich breaking, perfumed, mild subacid; quality excellent. Nov. to March.

Jonathan. Brilliant red; highly flavored and of excellent quality for either dessert or culinary use. It surpasses Spitzenburg in hardiness, vigor and productiveness, and is adapted to a wider range of territory. Every home or commercial orchard should have a large percentage of Jonathan trees. November to March.

King of Tompkins County. Very large, round, oblate; yellow striped and clouded; quality excellent. An abundant, annual bearer. November to March.

McIntosh Red. Fruit very attractive in appearance, of bright, deep red; flesh tender, crisp, juicy, highly perfumed, delicious; a dessert Apple excelled by none. Tree vigorous, hardy and healthy, comes into bearing young; a reliable and almost annual cropper. An ideal Apple from most any point of view. October to December and later.

Lowry. Beautiful, deep red, covered with small salmon-colored dots; high quality; flesh solid, very brittle, luscious and juicy; clear waxy, takes a high polish. Being planted extensively in the Virginia fruit-belts. A very promising variety, and we recommend it being planted in other sections. In a commercial way its prospects are very bright. A late keeper.

Mann. Fruit medium to large, roundish oblate, nearly regular; skin deep yellow when fully ripe; flesh yeliowish, juicy, mild, pleasant subacid. The tree grows straight and symmetrical, and becomes one of the largest in the orchard. It is an early and annual bearer.

Mammoth Black Twig. A very large and showy dark red Apple, resembling Winesap, but far superior in every way. The tree is a fine, upright, spreading grower, bears large crops and holds fruit well. A great favorite among commercial orchard planters. November to April.

Newton Spitzenburg. Roundish, medium size; yellow, washed with mixed red and striped with bright crimson; flesh yellow, fine, breaking, juicy, subacid; quality the best. An early winter Apple which, if placed in storage, is a late keeper.

Northerr Spy. Large; bright red, overspread with a delicate bloom; flesh juicy, crisp, tender and most excellent for kitchen or dessert. One of America's best Apples for local, general or fancy trade, always selling at better than average prices because of its size, beauty, fine flavor and high quality. Tree very hardy, healthy and vigorous, coming into bearing later than most sorts, and blooming very late. A heavy cropper, producing good yields where other sorts fail. November to March.
Northwestern Greening. A variety that is fast taking the place of the Rhode Island Greening, being much hardier, and is each year becoming more popular with the commercial orchard planter, especially in the northern states. The tree is very hardy and vigorous, and one of the strongest growers in the orchard. Very attractive in color, being a yellowish green; a good cooker and one of the best for general market on account of its late-keeping qualities. January to June.

Paradise (Winter Sweet). Sweet and good; a fine baking Apple, satisfactory for home or market; large; creamy yellow with blush cheek. Tree vigorous and productive. December to March.

Pewaukee. Medium to large, round oblate; bright yellow, flushed with dull red; flush white, tender and of the best quality. A very valuable Apple for commercial purposes on account of its beauty, quality and from the fact of its being one of the longest keepers. No home orchard is complete unless it contains this variety. January to May.

Rome Beauty. Fruit of good size, uniform, smooth and handsomely colored; flesh crisp, juicy, mild subacid, decidedly good; color greenish, splashed and striped with bright red. Tree a good, robust grower, giving good crops annually.

Stark. Medium to large, often very large, pale green, covered with bright red; flesh fine-grained, tender, juicy, mild, subacid. We do not believe the Stark Apple can be praised too highly; it ranks among the best in both the home and the commercial orchard. No Apple has a more ready sale in the general market. Tree is strong, vigorous and healthy, and an almost sure annual bearer. December to May.

Stayman's Winesap. One of the finest Apples grown for appearance, flavor and juiciness. A favorite for cider; medium size, conical; mostly covered with red on a yellow ground; flesh fine, crisp and high-flavored. November to April.

Surprise. Medium size; yellowish with crimson blush; flesh yellow, slightly stained, fine-grained, breaking, juicy, subacid, sprightly; of a strawberry-cherry flavor. No better for eating. A good keeper

Talman's Sweet. Medium size; pale, whitish yellow, tinged with red; firm, rich and very sweet; excellent for cooking. Upright and very productive. November to April.

\section{WE CANNOT ASK FOR A BETTER RECOMMENDATION}

Received Apple trees $O . K$, and in my opinion they are very fine. Very truly yours ARTHUR WYETH, Johnstown, Ohio.

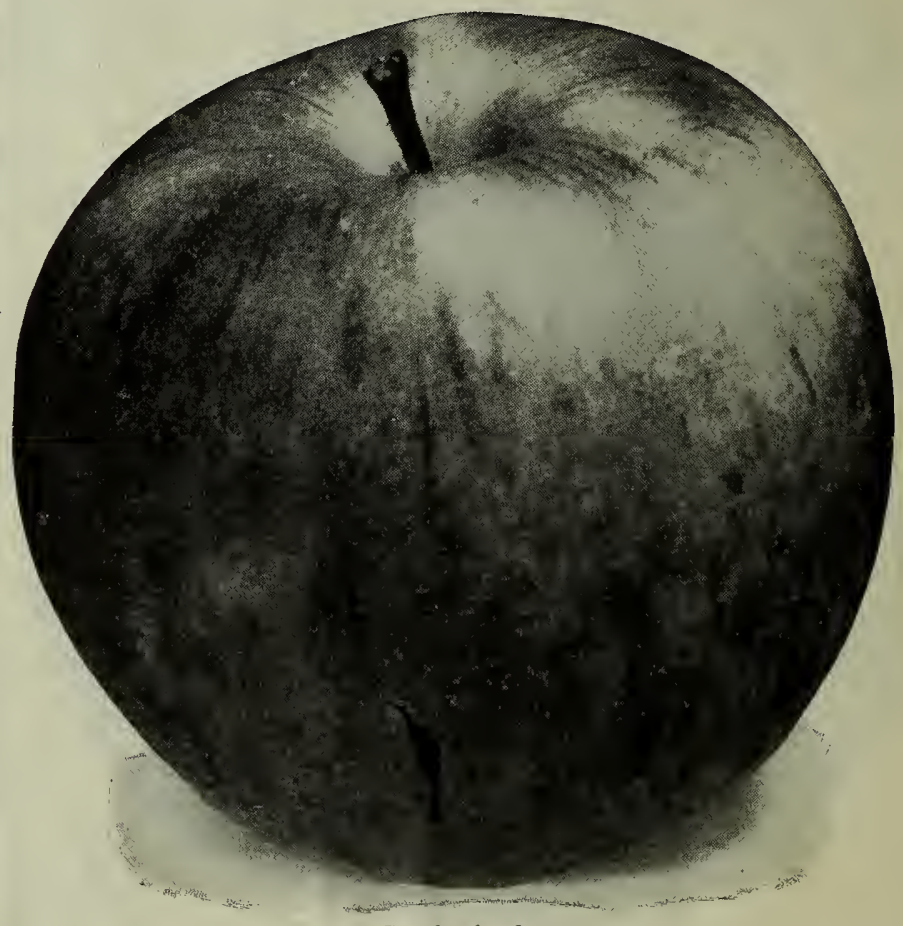

Stark Apple 


\section{WINTER APPLES, continued}

Wagener. An Apple of great excellence; highly colored, bright red with an attractive yellow ground for contrast. It is of fine texture, high flavor and excellent quality. Especially esteemed for dessert and an admirable Apple for culinary use. Tree is a good grower, upright, well formed and comes into bearing at an early age; yields moderate to heavy crops annually, it being necessary to thin the fruit. October to February.

White Pippin. A twin brother or sister to Yellow Newtown Pippin. It is inferior to Yellow Newtown in quality, but superior in every other way, doing well where Yellow Newtown will not fruit at all, and at its best a very profitable market sort. The tree is a good, thrifty grower, comes early into bearing, and is a great and reliable cropper. Fruit is of uniformly large size, roundish, oblate; pale yellow, sometimes blushed and mottled with brownish red; flesh yellowish, firm, fine-grained, tender, juicy, sprightly subacid flavor. October to February.

Winesap. The well-known, deep red market Apple of the West and Southwest. Of medium size and fair to medium quality; productive. Keeps from December to March.

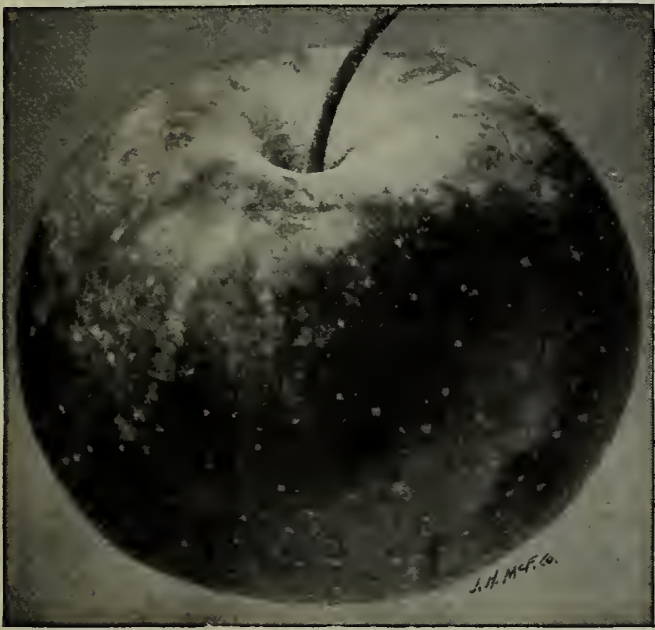

Whitney Crab Apple

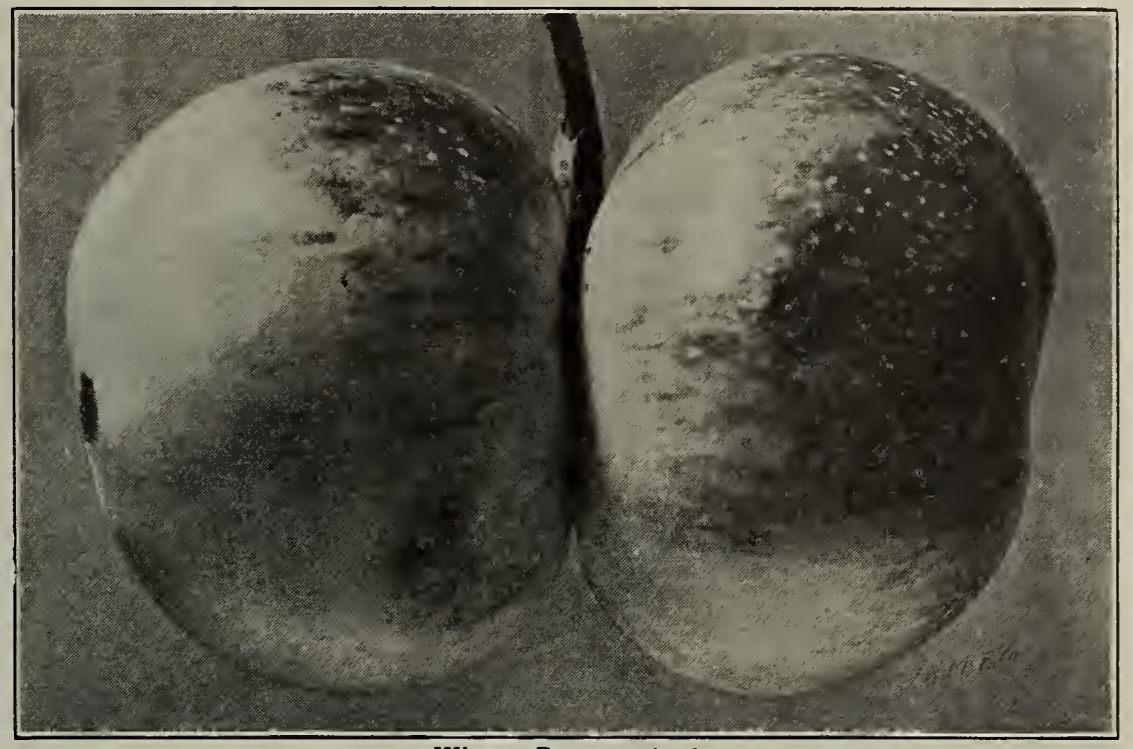

Winter Banana Apple

Winter Banana. Fruit large; clear, pale yellow, with beautiful contrasting pinkish red blush, attractive in appearance; characteristically aromatic, of good dessert quality; flesh yellow, very rich, juicy, breaking, splendid. The tree is a good grower, comes into bearing young, is almost an annual bearer, and yields moderate to rather heavy crops. November to April.

Yellow Bellflower. Large; yellow with a tinge of red; crisp, juicy; valuable for baking. Good bearer.

York Imperial. The Pennsylvania market and shipping Apple, long esteemed for its productiveness and the good quality of its fruit, which is quite distinct and attractive in appearance; of medium size, smooth, clear waxen yellow, flushed with carmine; the flesh is yellow, firm, of delightful flavor. Heavily planted in the commercial orchard. December to February.

THE MAN WHO IS THINKING OF PLANTING A LITTLE HOME ORCHARD CANNOT CHOOSE A BETTER LIST OF VARIETIES

\section{CRAB APPLES}

General Grant. Tree a good grower and of upright habit; a dark red Crab of good size and quality.

Hyslop. Very popular on account of its size, beauty and hardiness; large, dark red borne in clusters. Flesh is fine-grained, juicy and tender. October to January.

Transcendent. No better Crab Apple grown; largest and handsomest; skin bright yellow, red-striped; bears early. September to October.

Whitney. Tree very hardy and vigorous; a strikingly attractive, early $\mathrm{Crab}$ of fine size; glossy green, with carmine stripings, with firm, juicy, well-flavored flesh. August.

\section{DWARF APPLES}

Where the question of space is to be considered, we recommend the planting of Dwarf Apples. The man on the crowded city lot can have several choice varieties of Dwarf Apples on the same ground-space that is required for two or three standard trees. They bear from three to four years after transplanting, and even when not in fruit, their low, spreading, round heads are very ornamental. For many years after planting you can care for the tree and pick the fruit while standing right on the ground. The fruit on these little trees is just as fine in quality and, in some cases, even surpasses that of the standard tree. For descriptions see Standard Apple descriptions.

Varieties: Arkansas Black, Baldwin, Jonathan, Maiden Blush, Northern Spy, Oldenburg, Rome Beauty, Wealthy and Yellow Transparent. Two-year-old trees, 35 cts. each, $\$ 3$ for 10, in variety.

\section{APPLE COMBINATION, 25 TREES FOR $\$ 1.75$}

Best-quality Orchard Size
3 Yellow Transparent
4 Grimes Golden
4 Lowry
3 Baldwin
2 Winter Banana
2 Stayman's Winesap

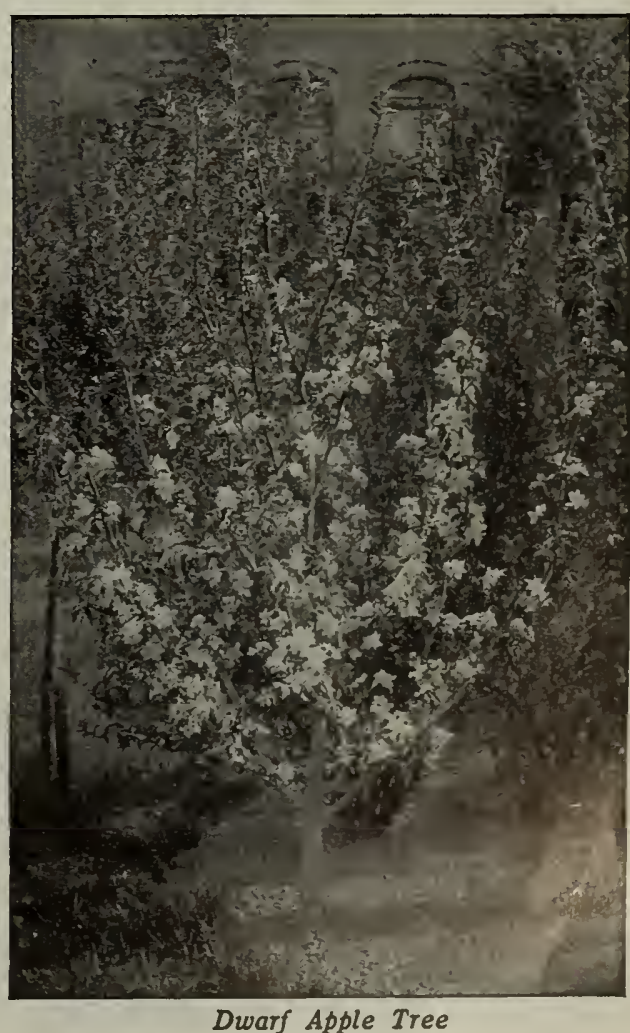




\section{PEARS}

Of late years much attention has been paid to the "breeding up" of the Pear, and today it is fast taking its rightful place as one of the best of fruits. The range of ripening of the different varieties is such that, if the planter uses care in his selections, he can have this fine fruit in the best of eating condition from early summer until late the following spring. Each year its market value is increasing; it does well in almost any good soil, but thrives best in a rather heavy clay or loam. Standards are best for permanent planting, while dwarfs are preferred where space is limited, or quick results are desired.

Many varieties of Pear are inclined to overbear. When the tree is heavily laden, the fruit should be thinned when about one-third grown, or else it will be small and the tree injured. Another important point in Pear-culture often neglected is the gathering of the fruit at the proper time. Summer and autumn Pears should be gathered about ten days to two weeks before they are ripe, and placed on shelves in any dry place.

Winter Pears should be left on the tree until the leaves begin to fall. They should then be gathered and stored in a dry cellar.

We have made quite an extensive study of the Pear and its many varieties, and consider the following highly meritorious of propagation, both for their yield and the quality of fruit,-in fact, varieties that should appear in every orchard.

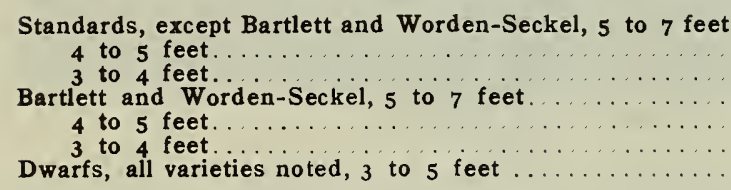

\section{SUMMER PEARS}

Bartlett. This fine old favorite is probably the best known and most highly esteemed of all the summer Pears. Rich golden yellow, with faint blush; skin quite thick; flesh rich, buttery, melting, highly scented. Tree a strong grower, bears young and prolifically. Standard or Dwarf. August.

Clapp's. A superb, large, long, yellow Pear, richly flushed with russet-red next to the sun, juicy and delightful. Ripens before Bartlett. Standard or Dwarf. August.

Koonce. Yellow, with carmine blush; very sweet, good, highly flavored. Recommended because of the fine quality of the fruit and on account of the vigor and resisting qualities of the tree. July and August.

Tyson. Above medium size; melting, juicy, sweet and pleasant. Tree very vigorous, bears abundantly. One of the best summer Pears. Standard or Dwarf. August.

Wilder. One of the earliest Pears known; a splendid market sort; fruit medium size, pale yellow, with russet shadings; flesh rich, melting, aromatic, delightful. Tree an abundant and prolific bearer. Standard or Dwarf. Early August.

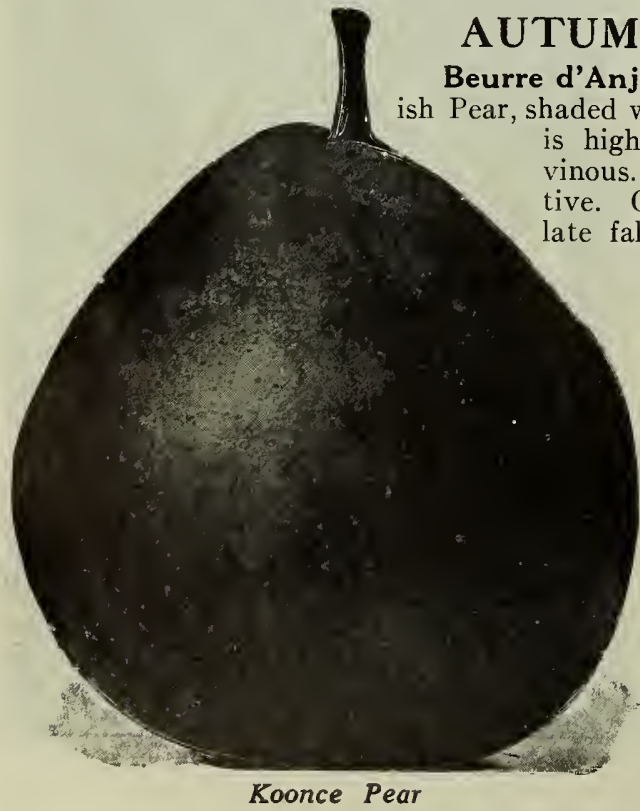

\section{AUTUMN PEARS}

Beurre d'Anjou. A large, greenwith russet-red; flesh Tred, rich and Tree very producive. One of the best for and early winter use. Standard or Dwarf. October to January.

Duch esse d'Angouleme. Among the largest of all our really good Pears. Green, tinted with russet; very juicy, tender, delight fully flavored; a fine market Pear and equally good for home use. $\mathrm{St}$ a nd ard or Dwarf. October and November.

\begin{tabular}{|c|c|c|c|}
\hline Each & Per & 10 & 100 \\
\hline So 40 & $\mathbf{S}_{3}$ & 50 & $\$ 3000$ \\
\hline 35 & 3 & 00 & 2500 \\
\hline 25 & 2 & 00 & 1500 \\
\hline 50 & 4 & 50 & 3500 \\
\hline 45 & 4 & 00 & 3000 \\
\hline 40 & 3 & 50 & 25 \\
\hline 35 & 3 & 00 & 2500 \\
\hline
\end{tabular}

\section{AUTUMN PEARS, con}

Flemish Beauty.

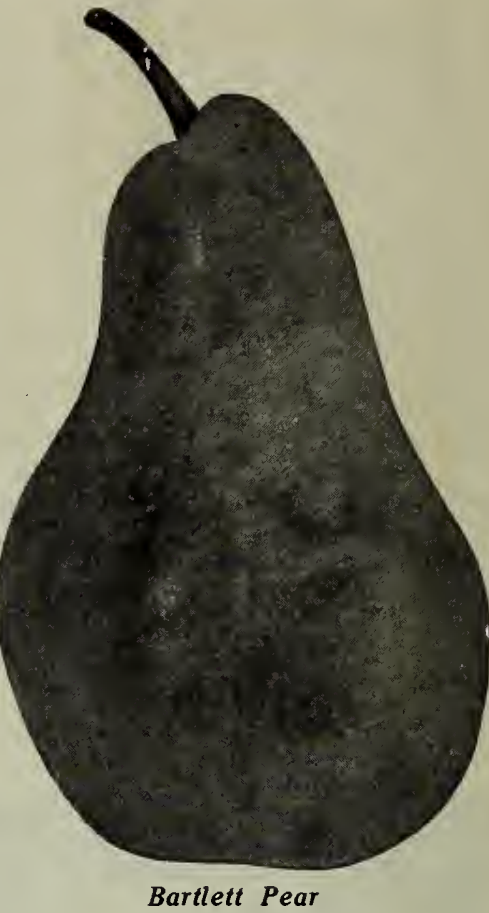

Fruit large, very attrac-

tive, of the highest excellence; known and esteemed by all. Tree hardy, prolific, bearing good crops in every latitude. Standard or Dwarf. September to October.

Garber. A valuable market Pear. Tree is a very thrifty, healthy grower, and a yearly heavy cropper. Fruit bright yellow, very attractive and good. October.

Howell. Tree makes a vigorous growth and bears young. Fruit attractive yellow, with rich, melting, aromatic flesh. Standard or Dwarf. September and October.

Kieffer. While not of the best quality, it is one of the favorite varieties for canning and preserving. A very profitable market sort on account of its good keeping and shipping qualities. Of extraordinary size and beauty. Tree almost blight-proof. Standard or Dwarf. October and November.

Rossney. Very large, with crimson blush; a very healthy, strong-growing Pear of the best quality; flesh tender, juicy, perfumed, luscious. Standard or Dwarf. September and October.

Seckel. One of the richest and highest-flavored Pears known, often called Sugar Pear. Always in demand for dessert. Tree makes a somewhat slow but stout and erect growth. Standard or Dwarf. September and October.

Sheldon. A large, round, russet-and-red Pear of the very first quality. Hardy, free-growing, fruitful. October.

Worden-Seckel. A worthy seedling of the famous old Seckel. Is superior to Seckel in flavor, size, beauty and keeping qualities. The fruit is beautifully smooth and regular, golden yellow with russet-red cheek. Tree makes a more rapid and upright growth than Seckel. Standard or Dwarf. October to December.

\section{WINTER PEARS}

Lawrence. The best early winter Pear. Of good size, golden yellow; rich, juicy, aromatic flesh. A splendid sort to bear, yielding large crops annually. Standard or Dwarf. November and December.

President Druard. A French Pear of great excellence. It is rich, of pleasing flavor, and keeps through winter. Large, aromatic, juicy, fine. Tree bears profusely and is very hardy. Standard or Dwarf. February and March.

Note.-A D warf Pear never attains the size of the Standard Pear tree, but the fruit is of the same size and quality. Where several varieties are wanted, and little ground-space available, Dwarf trees are advisable. Dwarf trees are indicated in the descriptions. 


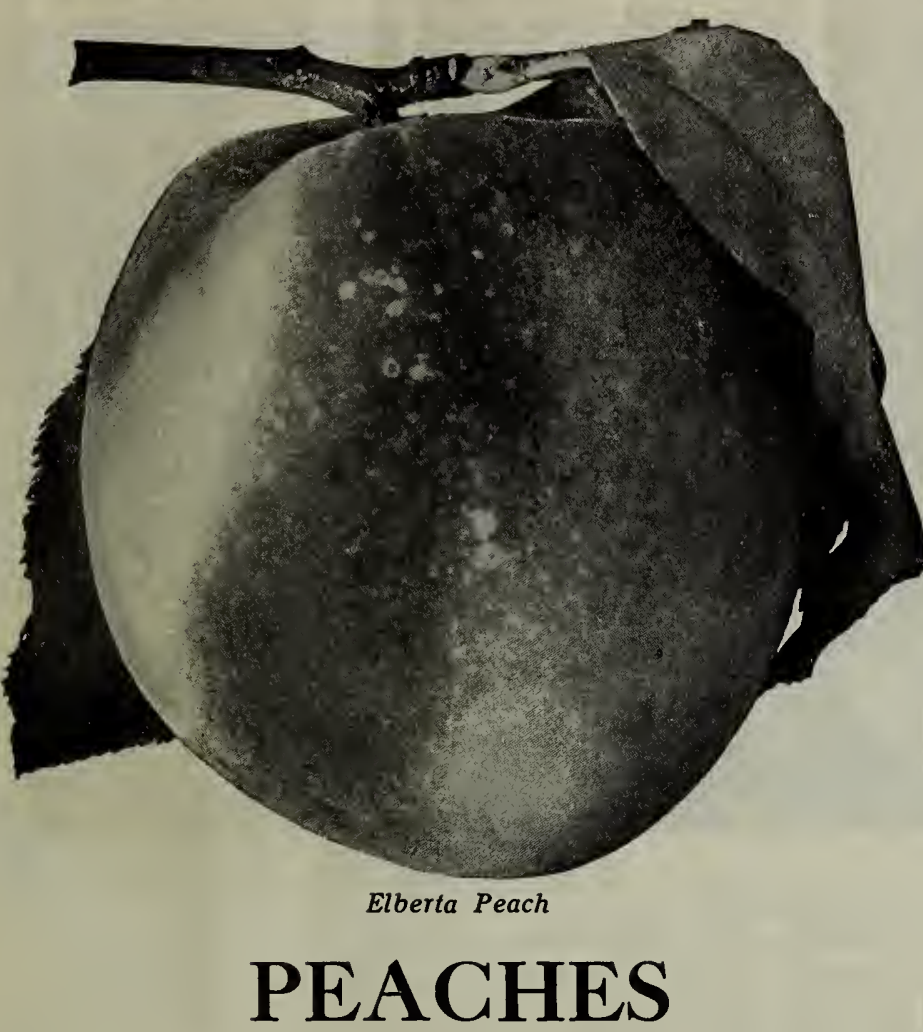

Three things make the Peach one of the most profitable of all fruits; viz., its comparative freedom from disease, the short period after planting before it becomes productive, and the immense demand for the fruit in all parts of the country. No commercial or home orchard is complete without a good assortment of this delicious fruit, made up of early, medium and late varieties. No fruit is more attractive in appearance or so desirable for dessert, whether fresh or canned.

The seedlings on which we bud our Peach trees are grown from native Tennessee pits, and, as our soil is especially adapted to Peach-growing, we make a specialty of trying to produce trees that are just a little better than the other fellow's. In this we feel that we have succeeded. We grow stocky, well-rooted trees, that will quickly respond to all the time, care and cultivation given them.

For your convenience, we have arranged our list of varieties as nearly in the order of their ripening as possible. We do not catalogue our entire list of varieties-only thirty-two of our leaders. Clingstone varieties are marked with a star $\left(^{*}\right)$. Each Per ro roo

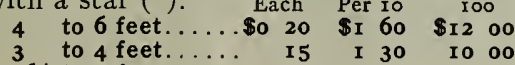

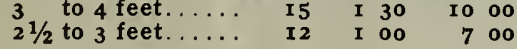

Admiral Dewey. Tree is a strong, hardy, symmetrical grower and produces well. A perfect freestone, of fine size, form and color, with delicious yellow flesh that is yet firm enough to ship well. July.

*Greensboro. The flesh is white, juicy and of delicious quality for so early a Peach. Earlier than the Alexander and twice the size. The largest and most beautifully colored of all the early sorts. July.

*Triumph. Another of the really good early Peaches. On account of its late blooming it escapes the late frosts, and is consequently an almost sure annual bearer. Fruit very handsome, bright yellow, with a deep blush; flesh yellow and tender. A freestone when fully ripe. July.
*Mayflower. Extremely early; of good size; beautiful, bright red all over. An unusually valuable market sort and a splendid shipper. Tree a strong grower; requires thinning for best results. July.

Mountain Rose. Of good size; skin richly splashed with light and dark red; flesh white and very delicious. Tree thrifty and fruitful. An old standby. Early August.

Carman. A very fine Peach of the Elberta type; creamy white, with deep blush; skin very tough, flesh tender, fine flavor and quite juicy, parting readily from the stone. Tree very hardy, grows and produces well. Early August.

Champion. A sweet, juicy freestone, beautifully colored with creamy white and crimson; a good shipper. Hardy, productive, profitable; none better of its season. A superb variety for home and local market. August.

Yellow St. John. Desirable for home use and profitable for market; orange-yellow with dark, rich red on sun-exposed side. A standard sort that is a favorite in many localities. A young and abundant bearer. August.

Crawford's Early. A magnificent, large, yellow Peach of good quality. Exceedingly vigorous and prolific; one of the most popular varieties. Late August.

Belle of Georgia. Fruit uniformly large and showy; skin white, with red cheek; flesh white, firm and of excellent flavor. Tree a rapid grower and very productive.

Fitzgerald. Of Canadian origin; unusually hardy and particularly adapted to cold climates. Bears very young and produces large crops. Fruit is large, bright yellow and of fine flavor. Highly recommended. Late August.

Foster. Large; deep orange-red, becoming very dark red on the sunny side; flesh yellow, rich, juicy, with pleasant acidity. Tree very thrifty. August.

Elberta. The greatest American market Peach, producing big, profitable crops annually in all sections of the country. Fruit is large, bright, attractive, yellow with crimson shading; flesh firm and good. Will ripen perfectly when picked green. Unexcelled as an all-round Peach. August and September.

Crawford's Late. One of the finest and most profitable Peaches in our list. Similar to Crawford's Early, but about three weeks later in ripening; fruit of the largest size. September.

Matthew's Beauty. Largely planted in commercial orchards in connection with Elberta. Large in size; golden yellow, streaked with red; flesh very fine-grained and of extra-good quality, a leader among shippers. September.

New Prolific. An exceedingly prolific, large, yellow Peach, with rich, firm flesh, small pit and fine flavor. A fine market sort. Tree very thrifty and hardy.

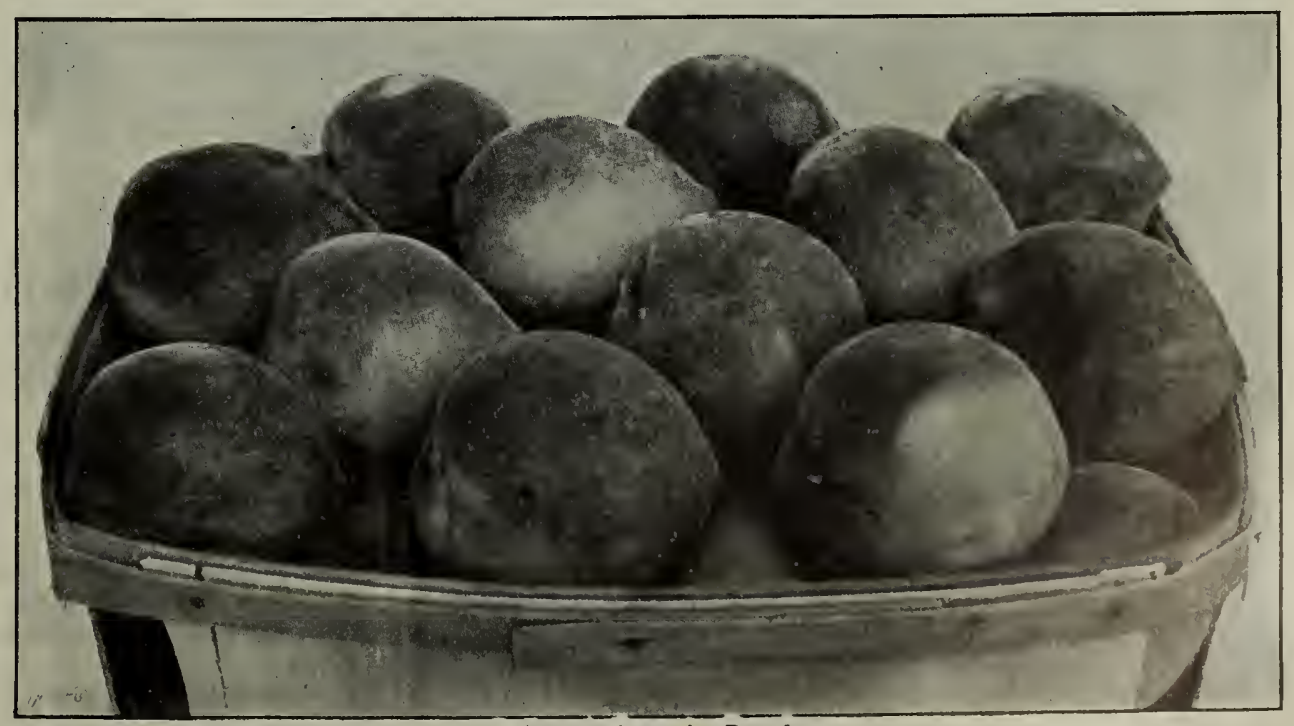

Belle of Georgia Peaches 


\section{PEACHES, continued}

Chair's Choice. Large size; deep yellow with red cheek; ripens about a week before Smock; flesh very firm and of good quality. Tree a strong grower and productive. September.

Crosby. An old favorite on account of the hardiness and productiveness of the tree, and the splendid quality of the fruit. Of good size and of a peculiar roundish flattened shape; bright yellow and of the best of flavors. September.

*Lemon Cling. Large, lemon-shaped; beautiful light yellow, blushed red; fine canning and preserving Peach. September.

Kalamazoo. A large, golden yellow Peach, with red cheek; flesh firm, delightfully flavored; pit small. A stronggrowing, hardy, productive variety. September.

Engle's Mammoth. Large, round, oval; suture slight; yellow with red cheek; stone small; sweet, rich, juicy. One of the very best market sorts. September.

Stump the World. Red and white, handsome; of good size and the best flavor; very productive. September.

Lemon Free. A very large, pale yellow Peach of lemon shape; often measures I 2 inches in circumference; flesh thick, juicy, best quality. A great canning Peach and most profitable to grow on account of its great productiveness.

Gold Drop. Very extensively grown in the northern fruit-belt. Its clear golden yellow flesh makes it very attractive and always commands the highest price in the market. Late September.

Reeves' Favorite. Fruit very large and round; skin yellow, with a fine red cheek; flesh deep yellow, juicy and excellent; peculiarly adapted to heavy soils. September.

Oldmixon Free. Large, roundish, slightly oval; pale yellow with deep red cheek; flesh tender, rich and good quality; succeeds well in all localities. September.

Smock Free. Well known and highly esteemed. Certainly a very fine, large Peach; rich, juicy and good. Widely grown among commercial orchardists. September.

Beer's Smock. One of the most profitable market sorts. A large, yellow-fleshed Peach, similar to Smock Free, but superior to it; ripens a few days later and is a better bearer. Late September.

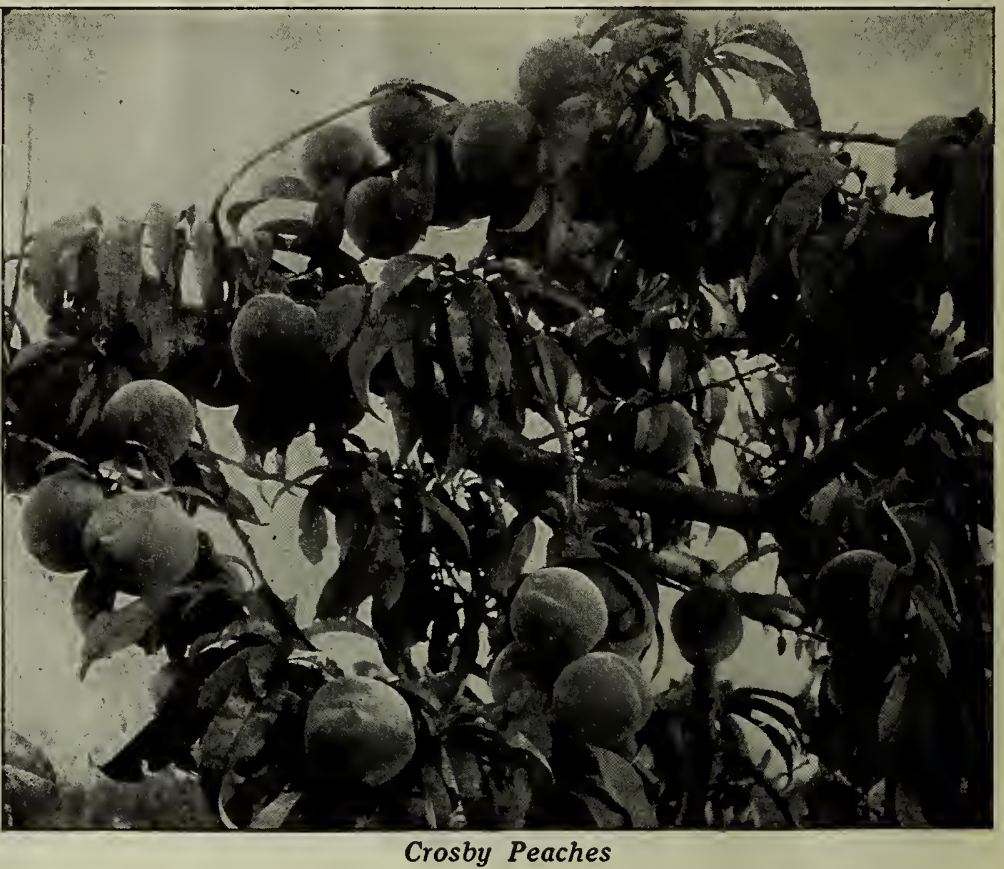

Wonderful. A seedling of Smock, and very similar to it but of superior quality. A splendid Peach for market. Late September.

Salway. Large, roundish; creamy yellow, with crimson cheek; the deep yellow, juicy flesh is melting, rich and sweet. One of the best late Peaches. October.

*Heath Cling. Very large; creamy white, with faint blush; of first-rate quality, long-keeping; valuable for preserving and canning. October.

Stevens' Rareripe. Ripens with the last of the Crawfords and is in season fully three weeks longer. A large, oblong, whitefleshed Peach, valuable for the beauty and high quality of its fruit, as well as for its early and heavy-bearing qualities. October.

\section{PLUMS}

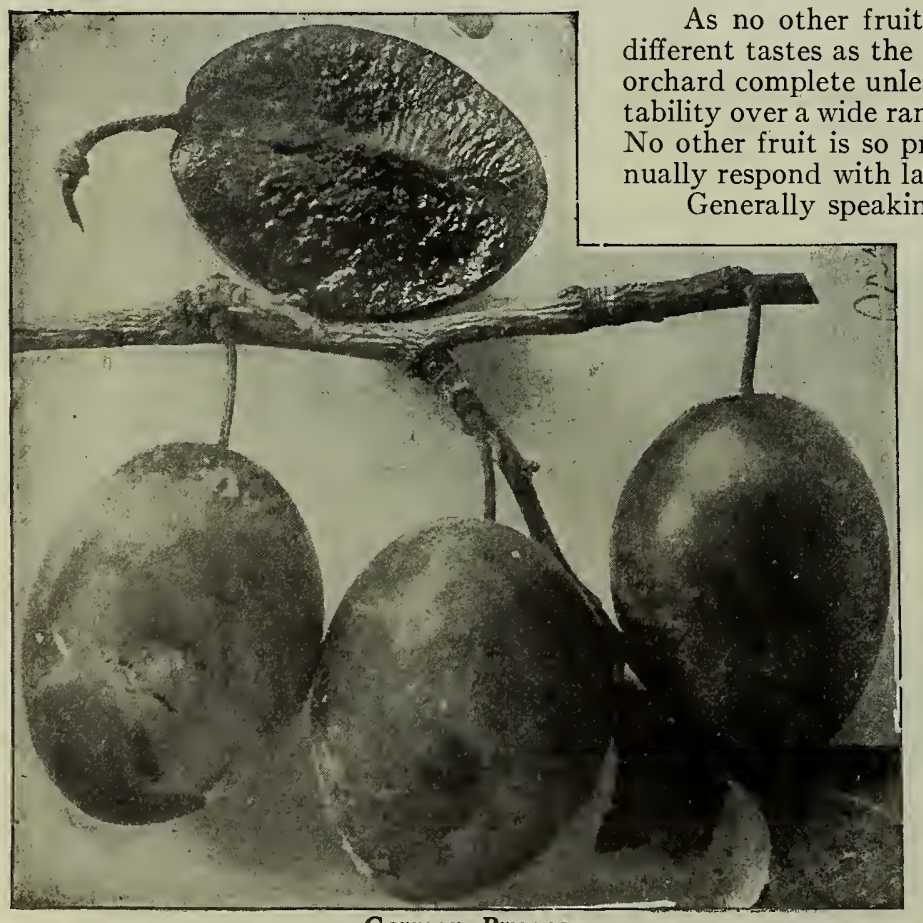

German Prunes
As no other fruit has a greater variety of uses, or is capable of satisfying as many different tastes as the Plum, its value in a commercial way is unlimited. Nor is any home unless it contains at least a half-dozen trees. It is of remarkable adaptability over a wide range of territory, and generously productive under nearly all conditions. No other fruit is so productive even if neglected; but, if given the proper care, it will anGespond with large crops of the finest fruit. , the Plum does best in a sandy or clay loam that is well drained, but will produce abundantly in almost any soil. The planter should keep his Plum orchard well cultivated, and should never allow it to become sodded with grass.

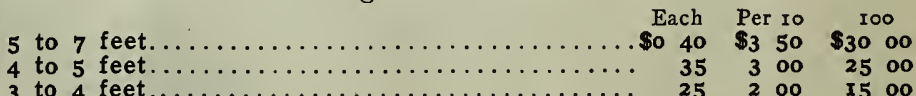

\section{EUROPEAN PLUMS}

Mostly of French origin, and comprise some of the finest fruits of the Plum family. Cultivate well and you will be richly rewarded for your work.

Bradshaw. Tree is an upright, vigorous grower. Fruit large, oval, obovate, sometimes with a slight neck; dark, velvety red; flesh tender, juicy, brisk, pleasant; adheres partially to the stone. August.

German Prune. A large, long, oval Plum, highly esteemed for canning and preserving. Purple with a thick bloom; flesh firm, sweet and pleasant. A good grower. September.

Grand Duke. Violet-red; large, showy; flesh fine-grained, juicy and of splendid quality; free from rot and a favorite for home and market. September. 


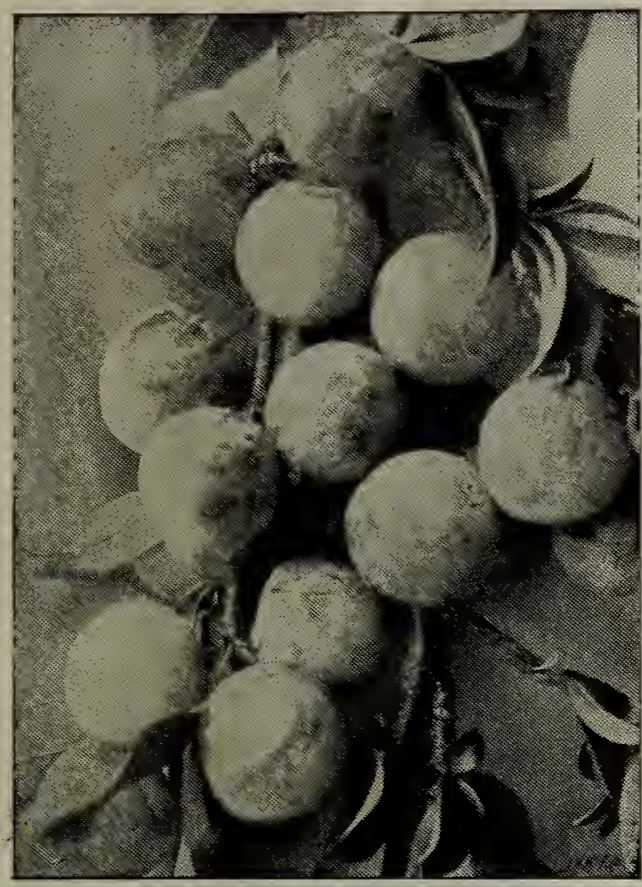

Burbank Plums

\section{EUROPEAN PLUMS, continued}

Geuii. While still young the trees are loaded with enormous crops. Vigorous and hardy; a fast grower. Fruit large, deep bluish purple, with thick bloom; flesh yellow, coarse, sweet and good. Early September.

Lombard. One of the best European Plums. Tree hardy, vigorous and one of the most prolific bearers; fruit handsome, attractive violet-red; large size. Splendid for eating out of the hand, and a general favorite for canning. Every orchard should contain Lombard. Late August.

Monarch. Round, bluish purple, with slight bloom; flesh greenish golden, pleasant and good. Freestone. Bears very young, and gives big crops. Profitable for market and good for home use. October.

Moore's Arctic. Small to medium, with purplish black skin and thin blue bloom; flesh juicy, sweet and fine-flavored. Tree is healthy, vigorous and a regular and abundant bearer. August.

Shipper's Pride. Large; dark purple, showy, with firm, well-flavored flesh. A wonderful shipper. Tree hardy and productive. Early September.

Shropshire Damson. The tree is enormously productive. Fruit medium size, about an inch long; skin purple, covered with thick blue bloom; flesh melting and juicy, rather tart, separates partially from the stone. September.

Yellow Egg. A large, beautiful yellow Plum of egg-shape and very sweet. Flesh adheres to stone; is of somewhat coarse texture but of splendid flavor. A fine market Plum because of its size, beauty and all-round good qualities. Late August.

\section{JAPANESE PLUMS}

Especially noted for their large size and beauty, making them very desirable market sorts, the flesh being so solid as to be very resistant to the sting of the curculio; they ship well and will keep for several weeks. We offer nothing but tried-out varieties.

Abundance. May be picked when it begins to color. Of good size; amber with markings of red; juicy, sweet, of good quality. Ripens and colors well after being picked, consequently no better for market. Tree exceedingly productive. August.

Burbank. No other Plum is so popular all over the country as the Burbank. Is perfectly hardy, succeeding well in any soil. Like the Abundance it ripens well after being picked, and will keep for fully three weeks in good condition after ripening. Fruit very large, nearly round and bright cherry-red. Its deep yellow flesh is sweet, meaty and quite firm. Should be kept well pruned. Early September.

Climax. Abundantly productive of its very large, heart-shaped fruit, which is deep, rich red, fragrant, sweet-fleshed and fine in every way. One of the earliest Plums to ripen. Tree strong, thrifty and hardy.

Red June. The long-keeping qualities combined with the size and beauty of this variety give it rank with the best Plums grown today. Handsome vermilion-red, with beautiful bloom; flesh light yellow, firm, fragrant, subacid. August.

Satsuma. Very large, nearly round; deep purple skin and flesh, firm and of good flavor; a good keeper. The tree is strong and thrifty and yields well. Always in brisk demand in the market. August.

Wickson. Flesh firm, sweet, tender and of excellent flavor. A rare keeper and shipper. Ranks high among commercial varieties. The yield is large. Fruit sells almost on sight. September.

\section{QUINCES}

The Quince is held in very high favor because of its many uses, such as canning, preserving and for flavoring other fruits. At the present time the demand for this fruit is much greater than the supply, consequently there is always a ready sale for it.

Grow a few Quince trees and take good care of them, and you will be highly repaid.

3 to 4 feet.

Each Per 10

Bourgeat. Tree a remarkably strong grower, surpassing all others; yields immense crops. Fruit of the largest size, round; rich golden color, smooth; very tender when cooked. With careful handling can be kept in the cellar until spring.

Champion. A prolific and constant bearer, fruit averaging larger than the Orange, more oval in shape, quality equally fine, and a long keeper. Bears extremely young.

Meech. Tree a young bearer and an unfailing cropper, a vigorous grower. The fruit is large, lively orange yellow, of great beauty and delightful fragrance; its cooking qualities are unsurpassed.

Orange. One of the best for cooking; a valuable, golden yellow Quince, widely planted; flesh firm, of good flavor. Bears most abundantly.

Rea's Mammoth. A superb fruit, averaging one-third larger than Orange; of the same form and color, fair and handsome, and equally as good, and by some preferred to any other for culinary purposes. Tree healthy, a thrifty grower and productive.

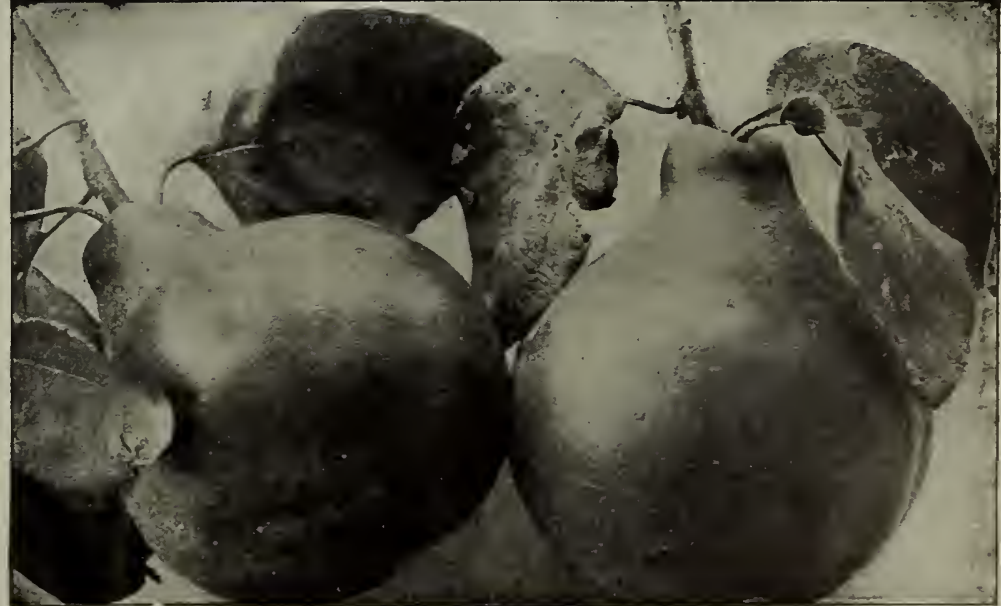

Rea's Mammoth Quince

\section{BIG-VALUE PEACH COMBINATION}

25 straight-bodied, well-branched, finely rooted Peach trees for $\$ 1.75$
5 Admiral Dewey
5 Fitzgerald
5 Beer's Smock
5 Champion
5 Elberta 


\section{CHERRIES}

There is no more desirable fruit than the Cherry, and it is being planted in larger quantities each year. No orchard is complete without a liberal proportion of this fine fruit. It will succeed in any dry soil, but attains its highest perfection in a sandy or gravelly loam. In our own opinion nothing surpasses the Cherry, especially for canning. As the tree itself is a beautiful grower, and also a most luxuriant bloomer, it not only takes its place as a leader of fruit, but also is very highly valued for its ornamental qualities. In fact, it is an ideal tree to be planted near the dwelling. Its commercial value is unsurpassed. Some of the standard sorts have been known to yield as high as $\$ 500.00$ net profit per acre.

We divide our Cherries into two classes, namely, Dukes and Morellos, made up of the sour sorts, and Hearts and Bigarreaus, the sweet varieties.

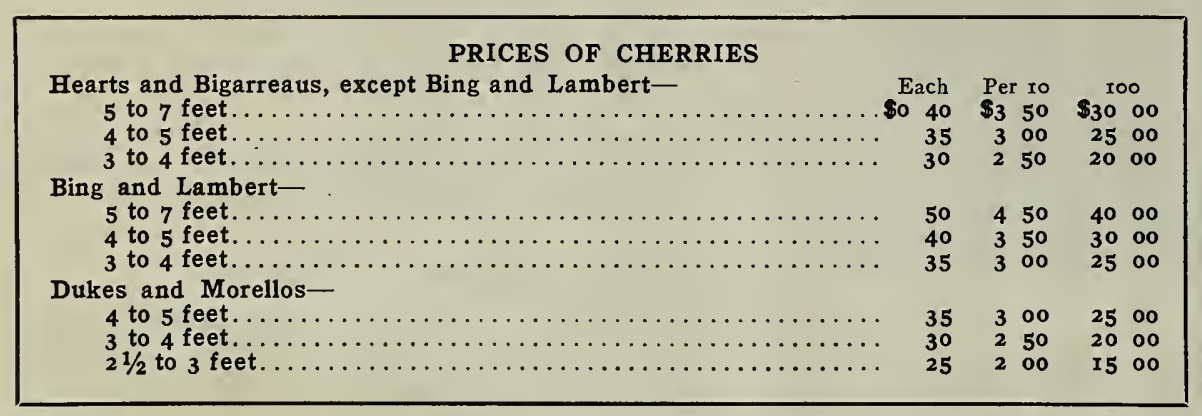

\section{DUKES AND MORELLOS}

Baldwin. Remarkable for its earliness, quality, vigor, hardiness and productiveness. Fruit is very large, almost round, dark red, slightly subacid; the sweetest and richest of the Morello type. Particularly profitable for commercial purposes. June.

Dyehouse. Ripens a week before Early Richmond, and is of a better size. One of the best early Cherries for home or market. Commercial Cherry orchards should contain a large percentage of Dyehouse, as it is a sure money-maker. June.

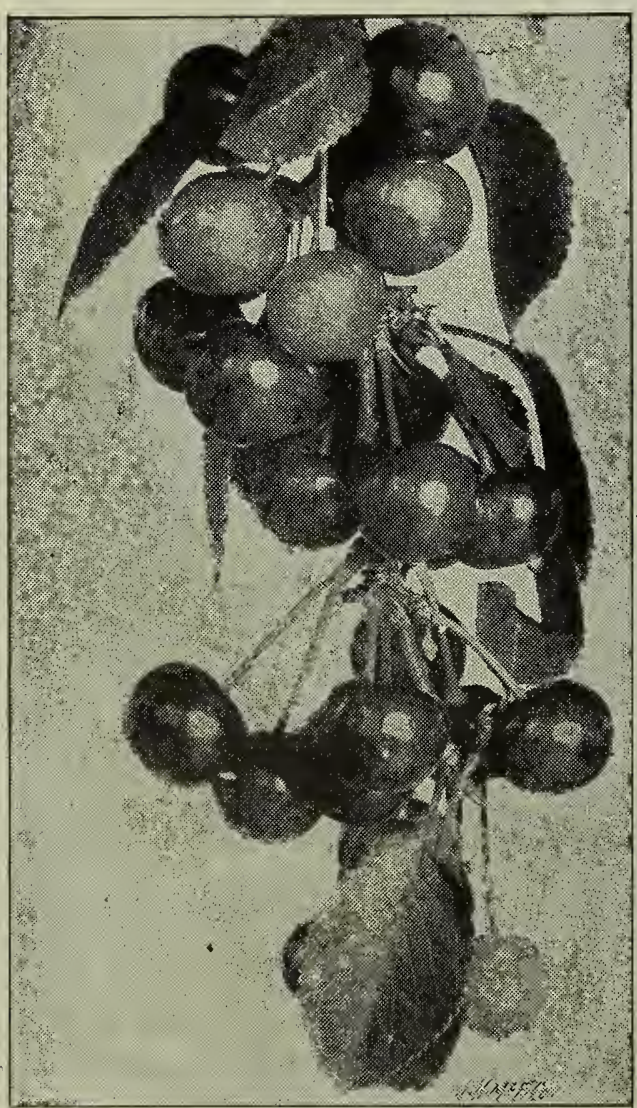

May Duke Cherries
Early Richmond. An exceedingly productive and reliable old variety, with light red fruits of medium size and sprightly acid flavor. A favorite for both home and market. June.

Large Montmorency. A prime favorite the country over. Bright red fruit, larger than Early Richmond and better in every way. Tree is a fine, thrifty grower and enormously productive. For canning and preserving no Cherry can surpass Montmorency. June.

Late Duke. Ripening late, toward the end of July, this sort should be in every collection of Cherries. Fruit very large, light red, fine and juicy. Tree strong, thrifty and very productive.

May Duke. Dark red; rich, juicy, finely flavored, of good size and of beautiful appearance. A superior and productive old sort that holds its place well against all newcomers. June.

Olivet. A fine, dark red Cherry, with red flesh; tender, rich, sweet and vinous. Unusually productive and largest of the Duke family. June.

Ostheimer. Tree blooms late, thus making it an almost sure bearer. Fruits quite young; large, heart-shaped, nearly black when ripe, juicy and rich; fine for dessert and cooking. July.

\section{HEARTS AND BIGARREAUS}

Bing. On the Pacific Coast, where Bing originated, this comparatively new variety is spoken of in the highest terms. Planters in the East find that it does well where other sweet Cherries fail. Very large; dark brown, almost black; flesh firm, sweet, rich and delicious. July.

Black Heart. Tree is a strong grower and very productive. One of the oldest varieties; heart-shaped, medium size; skin a deep, glossy black; flesh rich, juicy, tender, sweet. June.

Black Tartarian. Tree of unusual vigor and of erect, beautiful growth. A favorite everywhere. Very large; purplish black, with solid flesh; excellent flavor. Early July.

Governor Wood. Ripens in June, and ranks high in general esteem. A large, light Cherry of delicious flavor.

Lambert. Should be planted in connection with Bing, as it ripens a little later. One of the largest of all sweet Cherries; heart-shaped, dark purplish red, turning to almost jet-black when fully ripe. Flesh firm, rich and juicy, with sprightly flavor; tree very rugged, a strong grower and a most prolific bearer, Late July. 


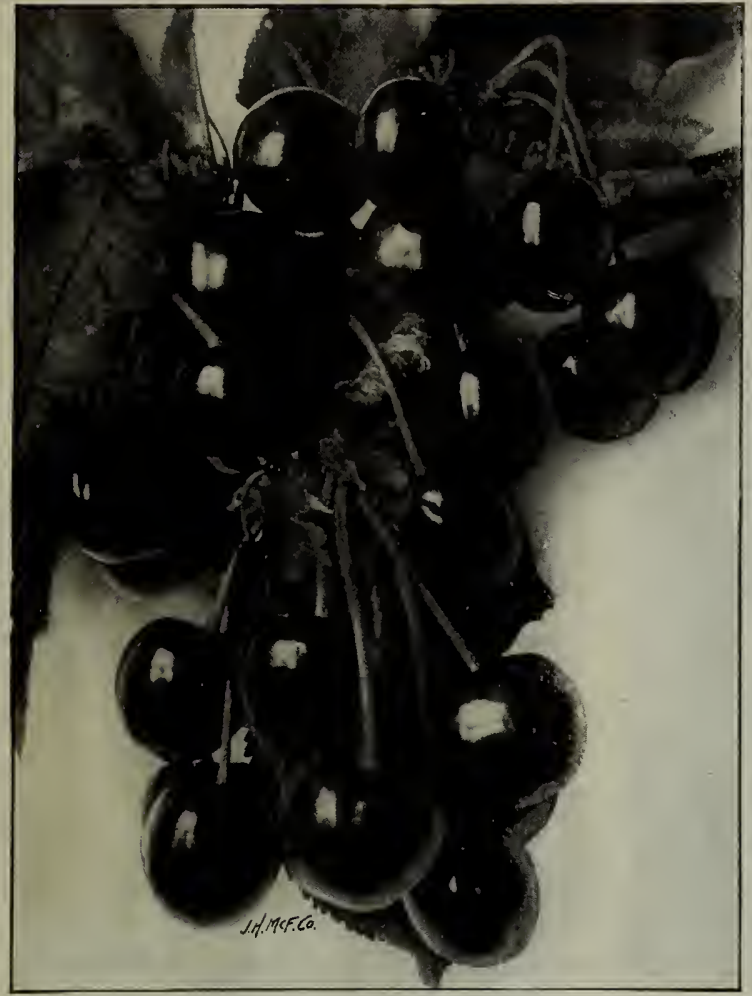

Black Tartarian Cherries

HEART AND BIGARREAU CHERRIES, continued

Napoleon. A pale yellow, red-cheeked Cherry of large size; flesh quite firm, juicy and of splendid flavor. July.

Schmidt's Bigarreau. A splendid market Cherry because of its attractiveness and general good qualities. Large; deep red, with dark, tender flesh, very juicy and of a most pleasant flavor. Tree one of the hardiest of the Bigarreau family, succeeding where others fail. July.

Windsor. Has very fine, firm flesh of high quality; a large, liver-colored Cherry, originating in Canada. Tree hardy and prolific. A splendid sort for home and market. July.

Yellow Spanish. Large; pale yellow, with bright red cheek; flesh firm, juicy, delicious. Late June.

\section{MULBERRIES}

Downing Everbearing. Tree very ornamental; bears very large, black, handsome fruit, of very rich flavor. 4 to $5 \mathrm{ft}$., $50 \mathrm{cts}$. each, $\$ 4$ for 10 .

New American. Fruit equals Downing in every way; tree somewhat hardier. Fruit ripens all through July and August. 4 to $5 \mathrm{ft}$., $50 \mathrm{cts}$. each, $\$ 4$ for ro.

Russian. A very hardy and rapid grower, bears very prolifically. Largely planted for hedge and windbreaks. 4 to $5 \mathrm{ft}$., $35 \mathrm{cts}$. each, $\$ 3$ for Io.

\section{APRICOTS}

The Apricot is a very welcome fruit, ripening, as it does, between the cherry and the peach. It requires the same treatment as the plum.

4 to 5 feet ..... Each Per ro 40 .

3 to 4 feet ..... $35 \quad 3$ oo

Alexander. A prolific bearer; fruit light orange, flecked with red; flesh tender, juicy, sweet and good.

Early Montgamet. Fruit large, round; deep yellow with fine blush; flesh yellow, juicy and excellent. Tree a good grower.

Moorpark. One of the largest Apricots; orange, with red cheek; flesh thick and wellflavored. Very productive.

\section{NUT TREES}

On the market, nuts are always in demand and command good prices. There is hardly another branch of tree cultivation from which there is assured such substantial profits. Not only are you each year reaping a large harvest of nuts, but at the same time the trees themselves are growing into many dollars in the form of very valuable timber.

Butternut. A fine native tree, producing a large, longish nut, highly prized for its sweet, oily, nutritious kernel, $21 / 2$ to $3 \mathrm{ft}$. $35 \mathrm{cts}$. each.

Chestnut, American. The fruit of this well-known native tree need hardly be described. We believe it is considered by all to be the best of all nuts, whether native or foreign. The tree itself is unsurpassable in an ornamental way. Timber very durable, possessing a very fine, straight grain. 4 to $5 \mathrm{ft}$. $40 \mathrm{cts}$. each, $\$ 3$ for Io.

Filbert, English. Tree of easy culture, succeeding well in almost any soil. Bears early and abundantly. Nuts almost round, rich and of excellent flavor. 2 to 3 ft. 35 cts. each, $\$ 3$ for ro.

Hickory, Shellbark. One of the best of all nuts. The tree is of very handsome and stately growth. The wood, on account of its great strength and elasticity, commands a high price. II $/ 2$ to $2 \mathrm{ft}$., 65 cts. each.

Walnut, Japan. Perfectly hardy; a rapid grower, bearing young and abundantly. Highly prized as an ornamental tree. Nuts resemble butternuts. 3 to $4 \mathrm{ft}$., $50 \mathrm{cts}$. each, $\$ 4$ for ro.

Walnut, Black. One of the most majestic trees of our native forests. Of rapid growth; timber very valuable, being used in the manufacture of fine furniture and in cabinet-making. Produces abundant crops of large, round nuts of excellent quality. 3 to $4 \mathrm{ft}$., $35 \mathrm{cts}$. each, $\$ 3$ for Io.

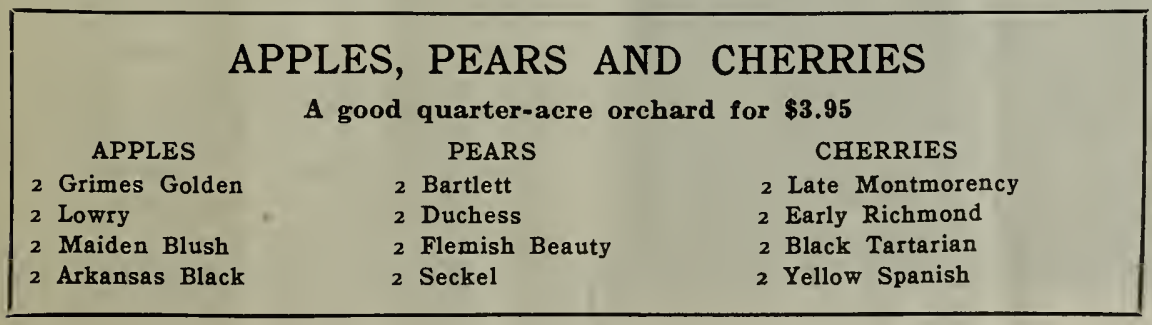

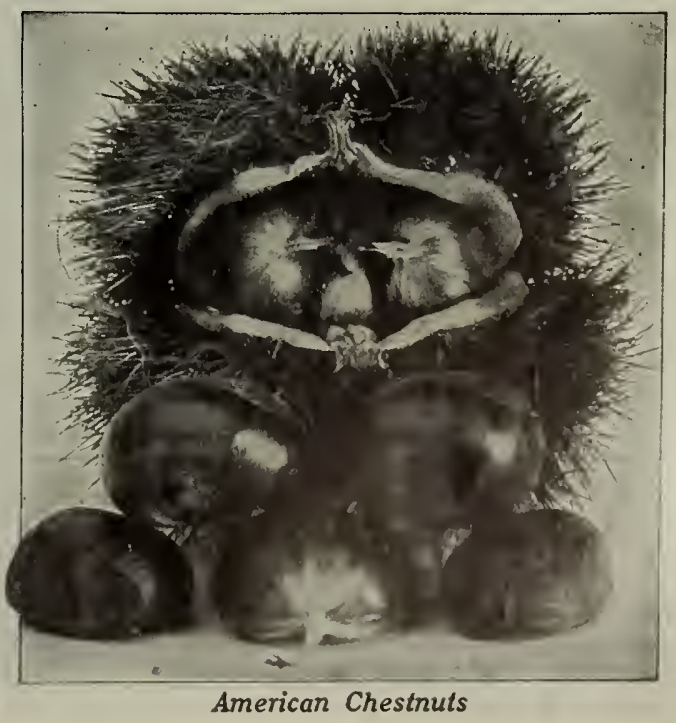




\section{Vines and Bush Fruits \\ SPECIAL QUOTATIONS ON ALL}

\section{GRAPES}

There is no yard so small but there is room for from one to a dozen Grape-vines. No fruit will give larger returns for close attention and good care. Turn a stony hillside into a vineyard, and otherwise barren ground will yield handsome profits.

The Grape may be confined to a trellis, run over an arbor, or extended until it covers a whole building, and still yield large clusters of most healthful fruit.

Careful attention must be paid to pruning, which should be done when the vines are entirely dormant.

Our plants are two years old, strong and well rooted.

\section{BLACK and PURPLE GRAPES}

Campbell's Early. A comparatively new Grape and undoubtedly one of the finest ever introduced. Forms large, shouldered clusters, quite compact; berries large, round and covered with purplish bloom. Adheres strongly to stem; skin thick and does not crack; tender pulp, parting readily from the small seeds; flavor very sweet, rich and delightful; colors early but requires some weeks to thoroughly ripen. A splendid keeper. abundant bearer. $35 \mathrm{cts}$. each, $\$ 2.50$ for 10 .

Concord. Very healthy, of vigorous habit and productive. Bunches rather compact, berries large, globular, almost black, thickly covered with bloom; skin rather thick; flesh somewhat buttery, moderately juicy, sweet, with considerable toughness and acidity in its pulp. It is very popular. For general cultivation the most reliable and profitable Grape. Io cts. each, $80 \mathrm{cts}$. for Io, $\$ 4$ per roo.

Moore's Early. Bunches of medium size, with large, round, black berries, heavily covered with bloom. Very early and, by reason of this and its reliability as a regular and prolific producer, is highly regarded as a profitable market Grape. I 5 cts. each, \$I for Io, \$7 per Ioo.

Worden. A very superior Grape that deserves to be a market leader. A seedling of Concord, but larger in bunch and berry, of better flavor, earlier, as hardy and healthy in every way, producing fine crops that command good prices. I 5 cts. each, $\$$ I for Io, $\$ 7$ per IoO.

\section{WHITE GRAPES}

Diamond. Large; bears in large clusters, compactly set; skin thin but-tough, flesh with little pulp, tender and juicy, of best quality. Vine an excellent grower, hardy and productive, with fine, large foliage. Ripens with Salem. I 5 cts. each, $\$ I$ for Io, $\$ 7$ per Ioo.

Green Mountain. An especially fine white Grape, among the earliest to ripen. Fruit and bunches of good size; quality of fruit excellent, very little pulp and few seeds, with a flavor unsurpassed by any Grape known. Vine hardy and prolific. 35 cts. each, $\$ 3$ for Io.

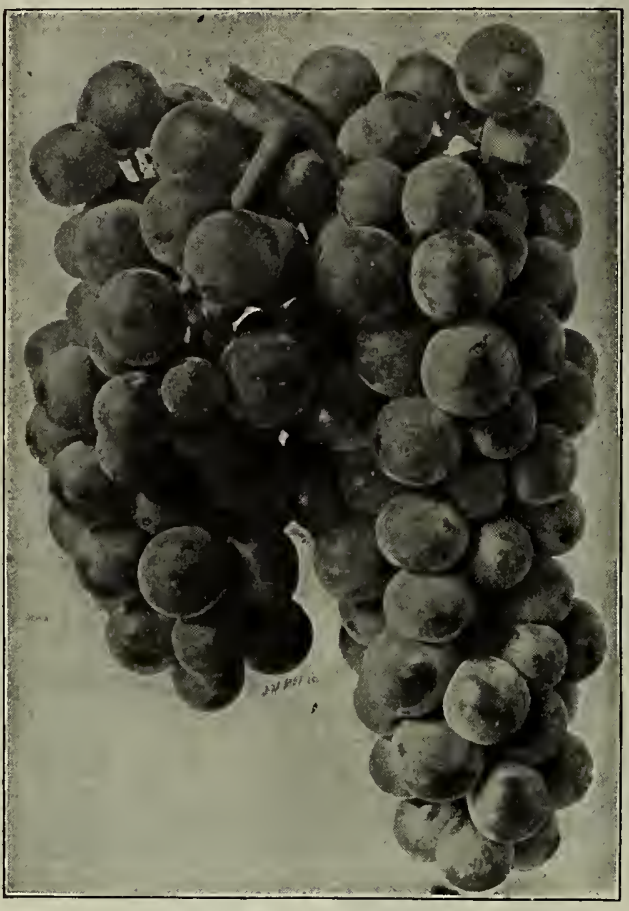

Campbell's Early Grapes
WHITE GRAPES, continued

Niagara. Home and market growers seem to agree that this is the most valuable of !all white Grapes. When fully ripe they are fine; pale yellow, with thin white bloom. The flesh is slightly pulpy, tender, sweet and delightful. Its clusters are large and handsome, compactly filled with large berries, having a thin, but tough skin. The vine is remarkably vigorous and productive. Ripens with Concord. I 5 cts. each, $\$$ I for Io, $\$ 6$ per Ioo.

Pocklington. Thoroughly hardy and healthy; bears well in favorable seasons and locations. Clusters and berries large; light golden yellow when fully ripe; sweet and tender, with little pulp. I5 cts. each, \$I for Io, \$6 per roo.

\section{RED GRAPES}

Agawam. One of the best-known, standard red Grapes. Berries quite large, with thick skin, compactly set upon a large bunch; soft, sweet and sprightly; ripens early. A fast grower and bears young. I 5 cts. each, \$I for Io, \$6 per Ioo.

Brighton. Bunches large and well formed, berries medium to large, of good flavor and quality. An excellent early Grape, ripening with Delaware. I5 cts. each, $\$$ I for Io, $\$ 6$ per Ioo.

Catawba. Bunches of medium size; berries round and of good size. Skin rather thick, pale red in the shade, but a pretty deep red in the sun, covered with a lilac bloom; flesh slightly pulpy, juicy, very sweet, with an aromatic, rich, musky flavor. Ripens from the first to the middle of October, and should be allowed to hang till fully ripe. I 5 cts. each, $\$$ I for Io, $\$ 7$ per Ioo.

Delaware. A favorite dessert Grape; it is moderately vigorous in growth, with short-jointed wood. Quite hardy. Bunches small, very compact; berries rather small; skin

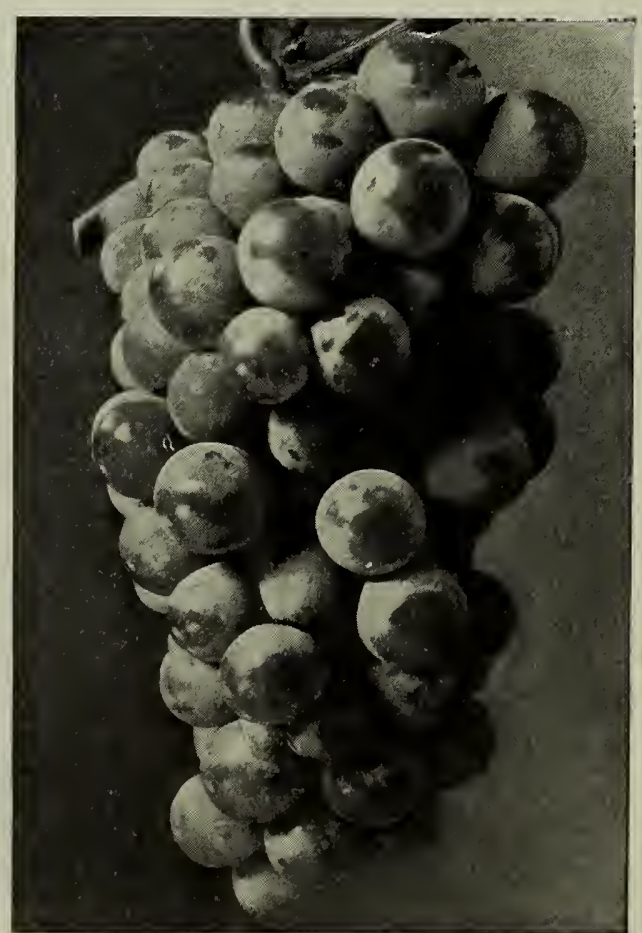

Niagara Grapes thin, of a beautiful light red. It is without hardness or acidity in its pulp, exceedingly sweet, but sprightly, vinous and aromatic. $20 \mathrm{cts}$. each, $\$ \mathrm{I} .50$ for Io, $\$ 8$ per roo.

Salem. Bunches large, short, broad and compact; berries large, round and a shade or two darker in color than Catawba. flesh tender, juicy, nearly free from pulp, sweet, aromatic and well flavored. Ripens soon after Delaware. I5 cts. each, \$I for Io, $\$ 7$ per Ioo.

Woodruff. Ripens early, with Delaware; keeps long and ships well. The vine is an ironclad in hardiness, makes a healthy, vigorous growth and bears good crops. A handsome and profitable market Grape, with large clusters and red berries of good quality. The best of all red market Grapes. $20 \mathrm{cts}$. each, $\$ 1.50$ for IO, $\$$ Io per roo.

\section{SOUR CHERRY BARGAIN, \$I.I5}

2 Early Richmond I Dyehouse 2 Montmorency * I Late Duke

Fine trees in every respect 


\section{CURRANTS}

Currants are perfectly hardy and will thrive in any climate. If grown in good soil and carefully taken care of, the yield is enormous. A heavy mulch in the spring, which tends to keep the ground cool and moist, is very beneficial.

Black Champion. Produces large crops of excellent fruit. Berries are of extraordinary size and good flavor. I $5 \mathrm{cts}$. each, \$I for Io, \$8 per 100.

Cherry. A general favorite among small-fruit growers, being very productive and one of the best of keepers. A strong grower, bearing deep red berries in large clusters. Io cts. each, 8o cts. for Io, \$5 per Ioo.

Fay's Prolific. Rich red berries, as large as those of the Cherry Currant, but of better flavor, with less acid; long-stemmed and easily picked. The demand usually exceeds the supply. Io cts. each, 80 cts. for Io, $\$ 6$ per Ioo.

London Market. The plant is extremely hardy and productive, and retains its foliage throughout the season. Bears beautiful red berries of large size, and is a reliable cropper. Ships well and is excellent for market either near or distant. Io cts. each, 8o cts. for 1o, $\$ 6$ per Ioo.

Perfection. This is one of the most productive Currants we have ever known, and in quality it is superior to anything in the market, being of rich, mild subacid

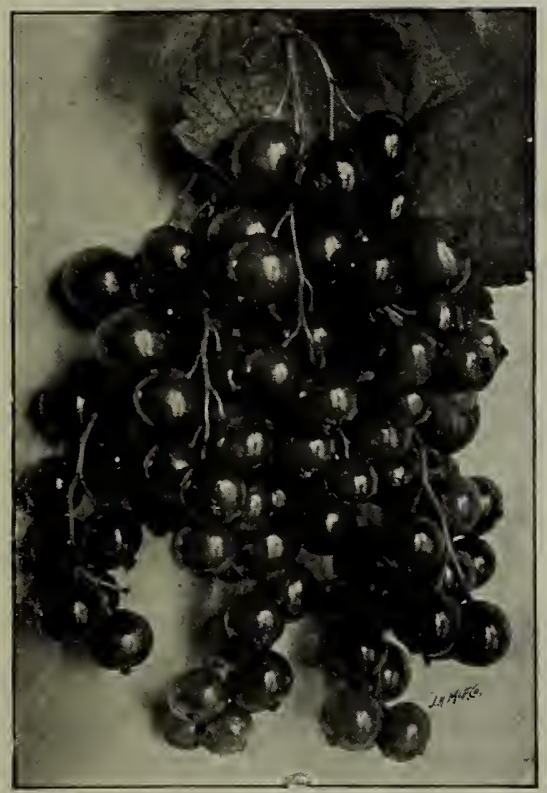

Victoria Currants flavor, and having plenty of pulp, with few seeds. In color it is a beautiful bright red, and of a size larger than the Fay; the clusters average longer and the size of the berries is maintained to the end of the bunch. This is one of the very best Currants for the market grower, as it presents a fine appearance when displayed and always brings the highest prices. 25 cts. each, $\$ 2$ for I0, $\$ 16$ per 100 .

Pomona. Deserves prominence for its splendid market qualities. The bushes bear early, and have an unparalleled record for actual acreage yield. The fruit is of good size and flavor; bright red; long-stemmed; hangs in fine condition long after ripening; ships and markets well, and is always eagerly sought for making jellies. Io cts. each, 80 cts. for 10, $\$ 5$ per 100 .

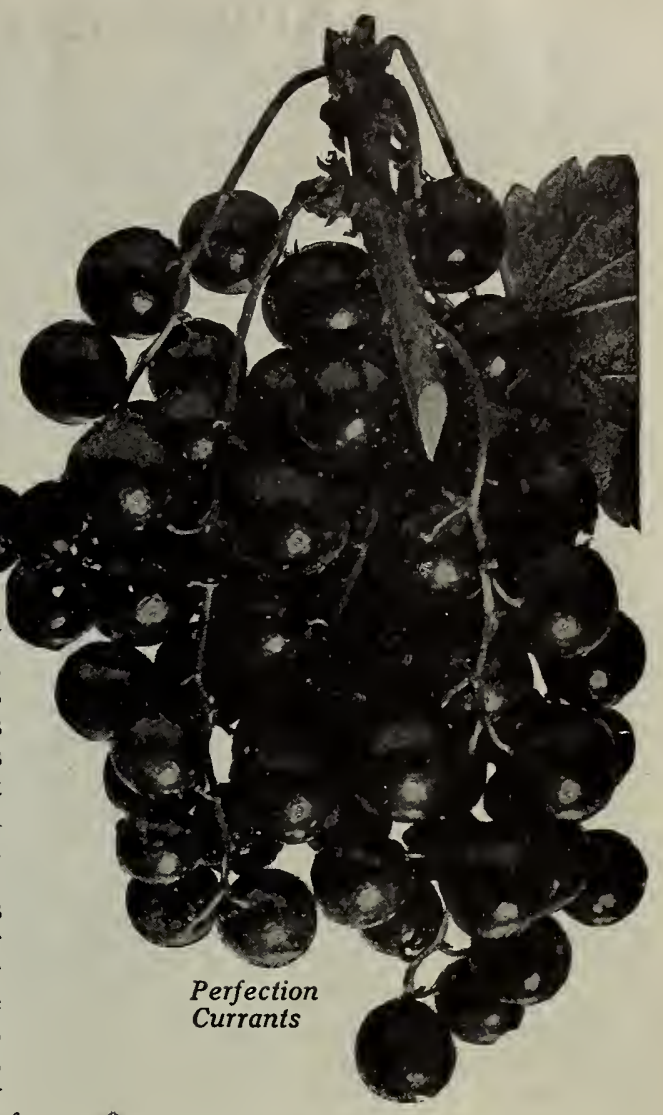

Victoria. Bunches rather long, of a bright red, growth slow, spreading and very productive. Will hang on the bushes some two weeks longer than most Currants, which makes it one of the most satisfactory for the home garden. A very excellent, rather late sort. Io cts. each, 80 cts.. for ro, $\$ 5$ per Ioo.

White Grape. Berries very large; whitish yellow; sweet and of excellent flavor. Very productive. Bunches moderately long. The finest white sort grown. Io cts. each, 80 cts. for 10, \$6 per 100.

Wilder. Few varieties equal it in the two essential qualities, productiveness and longkeeping. Red, with large, fine-flavored, bright, attractive fruit. ro cts. each, 80 cts. for ro, $\$ 5$ per 100.

\section{GOOSEBERRIES}

The Gooseberry is one of the hardiest types of the bush fruits, and is so useful for cooking, whether green or ripe, and can be canned with such facility that it is beginning to be very extensively cultivated for both home and market. It requires good, rich soil and plenty of moisture to reach a high state of perfection. Mulching is advisable.

Downing. Light green; large; fine flavor; bush very hardy and seldom mildews. One of the most profitable sorts for either home or market. I $5 \mathrm{cts}$. each, \$1.20 for Io, \$ro per roo.

Houghton. A vigorous grower. Branches rather drooping, slender; very productive, generally free from mildew. A desirable sort. Fruit medium, roundish, inclining to oval; skin smooth, pale red; flesh tender, sweet and very good. I 2 cts. each, \$I for Io, $\$ 8$ per Ioo.

Industry. A large, dark red berry, of great beauty and high quality. An English berry, and the only one which does as well as our native sorts. A prolific sort which should be in every collection. $25 \mathrm{cts}$. each, $\$ 2$ for ro.

Josselyn. The one large Gooseberry that can be planted with entire confidence. Large, smooth, of good flavor; the bush is very hardy, with clean, healthy foliage, and bears fine crops of bright red fruit. $20 \mathrm{cts}$. each, \$I. 5 O for IO, \$1 2 per roo.

Portage. Of Ohio origin and of fine size and all-round good qualities. It is practically mildew-proof and a heavy cropper. Very profitable for commercial growing. $30 \mathrm{cts}$. each, $\$ 2.50$ for 10.

Smith's Improved. In growth of plant, very upright and vigorous. The fruit is large and somewhat oval in form, light green, with a bloom; flesh moderately firm, sweet and good. $20 \mathrm{cts}$. each, \$1.50 for 10, \$1 2 per 100.

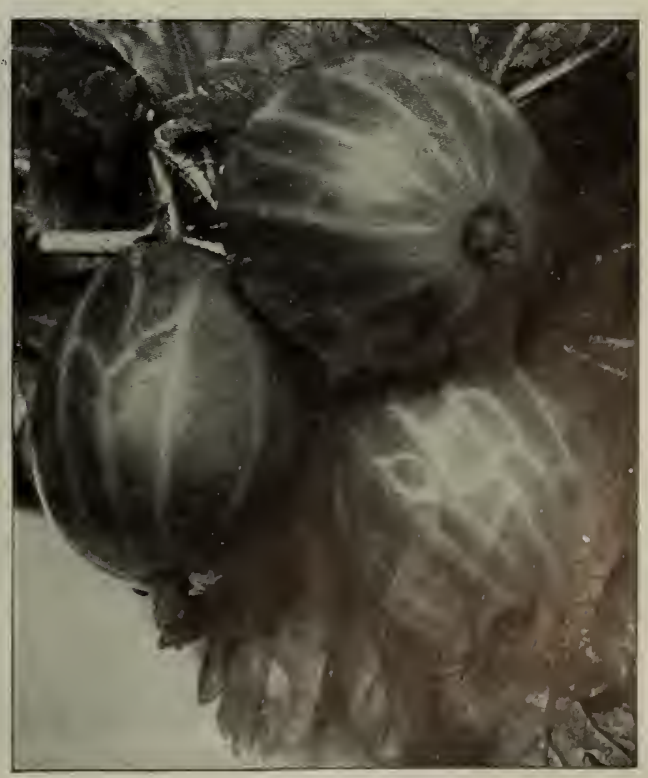

Industry Gooseberries 


\section{RASPBERRIES}

Plant 3 feet apart in rows 5 to 7 feet apart. To keep plants in good bearing condition, cut old wood away as soon as it has fruited. This treatment puts all the strength of the roots into the young canes that are coming on to produce next year's crop. Pinch back Blackcap varieties when they attain a height of about 2 feet, thus keeping the bushes snug and compact, and at the same time making staking unnecessary.

To secure the best results, cultivate your Raspberries frequently, and mulch both summer and winter.

\section{BLACKCAPS}

Prices, unless otherwise noted, 50 cts. for $25, \$ 1.50$ per roo, \$ro per r,000

Conrath. A fine market berry, sweet and delicious; berries large. A hardy, productive Blackcap, ripening a week before Gregg.

Cumberland. Its great, glossy berries outsell all others of their season, are firm enough to ship well, and of good quality. A mammoth midseason Blackcap that loads its stout, stocky canes with handsome fruit. In hardiness and productiveness none better.

Gregg. Its large, showy berries, produced in great abundance, are firm and ship finely. For many years the leading Blackcap for market. Midseason.

Kansas. The berries are large, showy, firm and of best quality, selling for top-notch prices. So strong and hardy as to endure extreme cold and drought, and yet bear heavy crops. One of the best Raspberries we grow.

Munger. Commands a better price than any other sort. Canes strong, upright, hardy; a berry you will make no mistake in planting for home or market; fruit firm, of largest size and delightful flavor. One of the finest for canning. $75 \mathrm{c}$. for $25, \$ 2.25$ per Ioo, $\$ 20$ per I, 000.

Palmer. The first Blackcap to ripen. Being very early, it commands good prices in the market. Wonderfully fruitful and quite hardy. Berries very solid and of good size.

\section{RED AND PURPLE RASPBERRIES}

Cardinal. The fruit is large and of excellent flavor. The canes are of very sturdy growth, and annually bear great loads of berries. This is the best of all purple Raspberries by whatever standard it is measured, and without a rival in point of productiveness. $\$ r^{\text {if }}$ for $25, \$ 2.50$ per I00, \$20 per I,000.

Cuthbert (Queen of the Market). Its berries are sweet, rich, high-flavored, as beautiful as strawberries, and so firm that they are shipped hundreds of miles in good condition. This superb old variety endures northern winters or southern summers with equal vigor, and produces fine crops of large, conical, deep red fruit, even

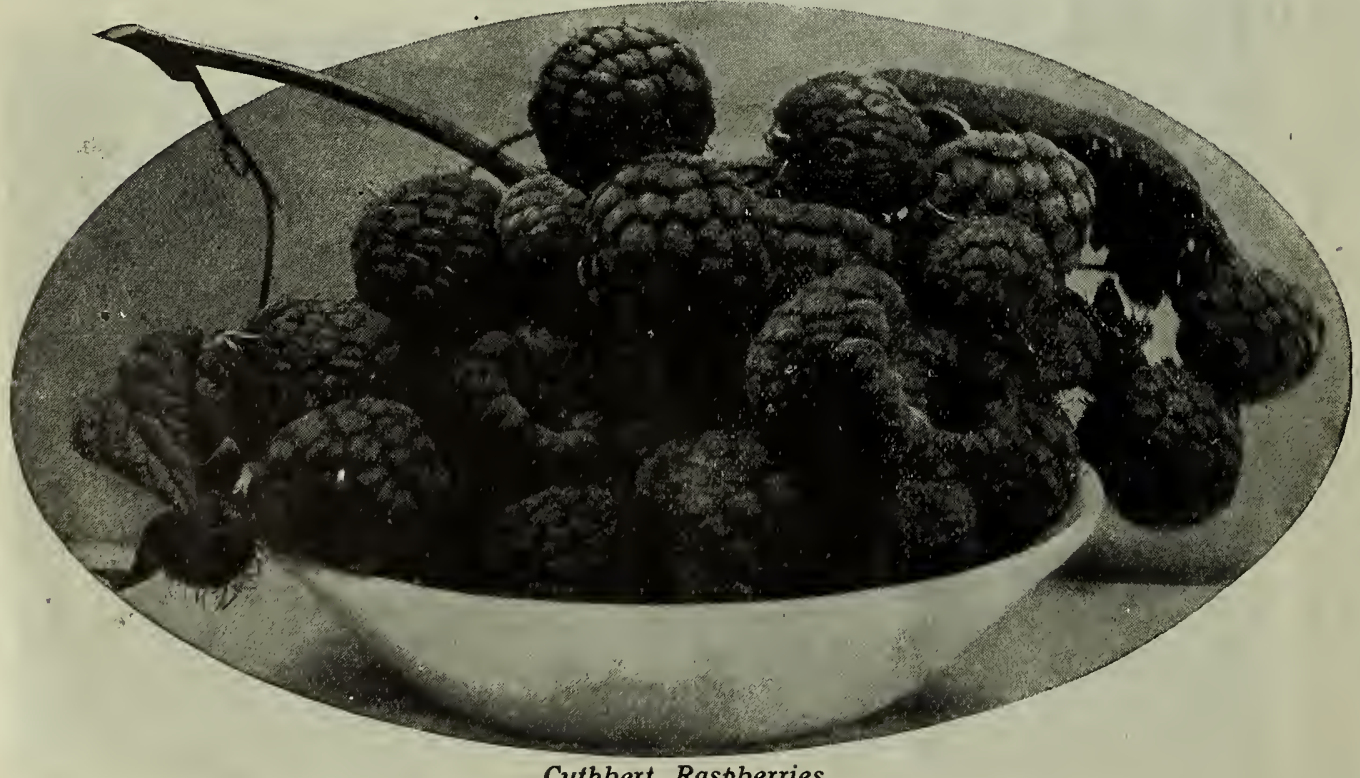

Cuthbert Raspberries

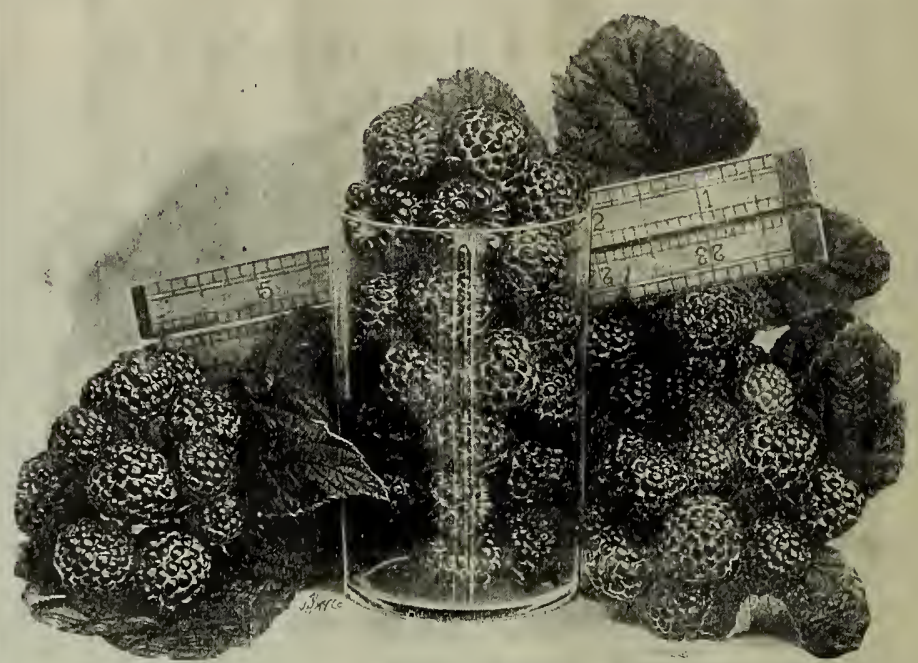

Cumberland Raspberries

in the cotton-belt, where so many other sorts fail. Certainly one of the finest market berries.

Eaton. A strong, sturdy grower, throwing out many laterals and fruiting to the tips and from every lateral, a sight to see. A red Raspberry entirely distinct from all other varieties. In character of growth, in size, color, firmness, quality and yield of fruit, in length of season, and in all strong points it is one of the best. An immense cropper, while the fruit is extraordinarily large and handsome, firm, of the highest quality, and is a particularly good shipper. \$1.25 for $25, \$ 4$ per Ioo.

King. A large and attractive, bright red fruit of good flavor, ripening with the earliest and firm enough to ship nicely. Several of our best fruit-growers consider this the best of the red Raspberries. In hardiness, growth and productiveness all that could be desired. 75 cts. for $25, \$ 2$ per I00, \$15 per I, 000 .

Loudon. A superior, dark red berry, favored by commercial growers because of its vigor, productiveness and the large size of its fruit. We consider it among the most desirable. $75 \mathrm{cts}$. for 25, \$2 per Ioo, \$I 5 per I,000.

St. Regis. Is the only Raspberry, thus far known, that will yield a crop of fruit the first season planted. Plant St. Regis in early April, and it will give you ripe berries the twentieth of June the same season. From the last of June to the middle of October you can pick fruit from the St. Regis plant, the only Raspberry on the market today that will bear large, beautiful, firm and fullflavored berries for four straight months of every year. Comes first and is last to go. This makes it one of the most valuable Raspberries for the home garden as well as for market. It is so firm that it will stand shipping hundreds of miles, arriving at its destination in the very best condition. It succeeds upon all soils whether light and sandy or cold heavy clay, and the canes are absolutely hardy, always and everywhere, so far as tested. Anyone who plants this variety will waste space and time to plant any other red Raspberry, for it is unsurpassed in excellence of fruit and covers the whole season, from earliest until latest. It is not a joke, but the exact truth to say, "It is the whole thing." I5 cts. each, $\$ 3$ for 25 , \$ro per Ioo. 


\section{DEWBERRIES}

Lucretia. The vine is perfectly hardy, healthy and exceedingly fruitful, with large, showy blossoms. In size and quality this lowgrowing or trailing Blackberry equals any of the upright sorts. Its berries ripen before raspberries are gone, are large, soft, sweet and luscious throughout, with no hard core. May be grown over walls, trellises or rocky slopes, where there is no room for other berries. $75 \mathrm{cts}$. for $25, \$ 2$ per roo.

\section{BLACKBERRIES}

For field culture, plant 3 feet apart in rows 6 feet apart; for garden culture, plant 4 feet apart in rows 5 feet apart. Pinch back canes when they reach a height of 3 to 4 feet, which produces a bushy growth and thus doubles the fruiting capacity of each plant.

Ancient Briton. Markets well. The strong, healthy canes are heavily laden with sweet, melting berries of medium size. Well adapted on account of its great hardiness for planting in all sections subject to severe winters. 75 cts. for $25, \$ 2$ per 100 .

Blowers. Claimed to be the hardiest, the most productive, the finest quality, and to bring on the market the highest price of all Blackberries. Has produced 2,694 berries on one bush, 2,720 quarts on one-third of an acre, and netted $\$_{344.25}$ profit per acre. Berry very large, jet-black, of best quality and a good shipper. Unexcelled in productiveness. $\$_{1.25}$ for $25, \$_{3.5}$ per Ioo.

Early Harvest. Canes dwarfish in habit. In sections subject to cold winters should be protected. Yery desirable on account of its early ripening. SI for $25, \$ 2.50$ per roo.

Eldorado. The berries are large, jet-black, borne in large clusters and ripen well together; they are very sweet, melting, have no hard core and keep for eight or ten days after picking with quality unimpaired. The canes are very hardy and vigorous, enduring the winters of the far Northwest without injury, and their yield is enormous. SI for $25, \$ 2.50$ per roo.

Erie. The canes are strong, with healthy foliage, hardy, free from rust, supporting heavy crops of fruit. Berries large and nearly round, appearing thus even larger than they really are. Of good quality. SI for $25, S_{2} .50$ per 100 .

Mersereau. An enormous producer of extra-size berries, which are brilliant black and retain their color; extra quality, sweet, rich and melting, without core. Remarkably strong grower, upright, producing stout, stocky canes. Claimed to be the hardiest Blackberry, and has been known to stand 20 degrees below zero

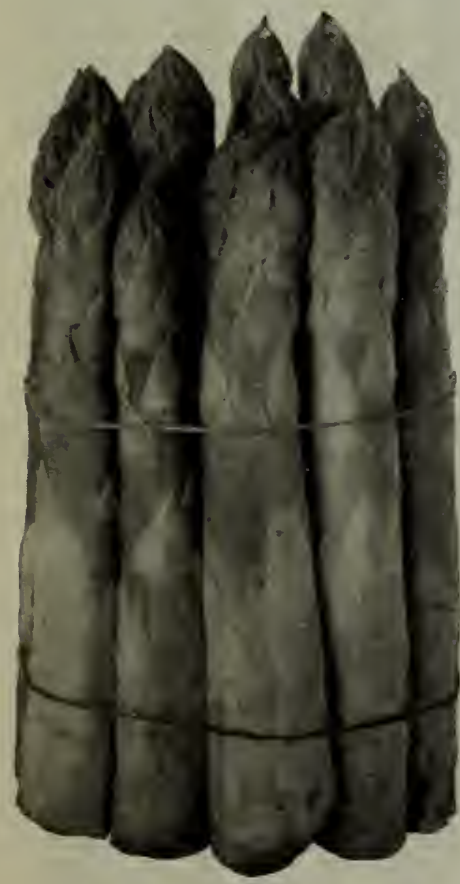
without protection. \$r for 25 , S2.50 per roo. ular sort. second year.

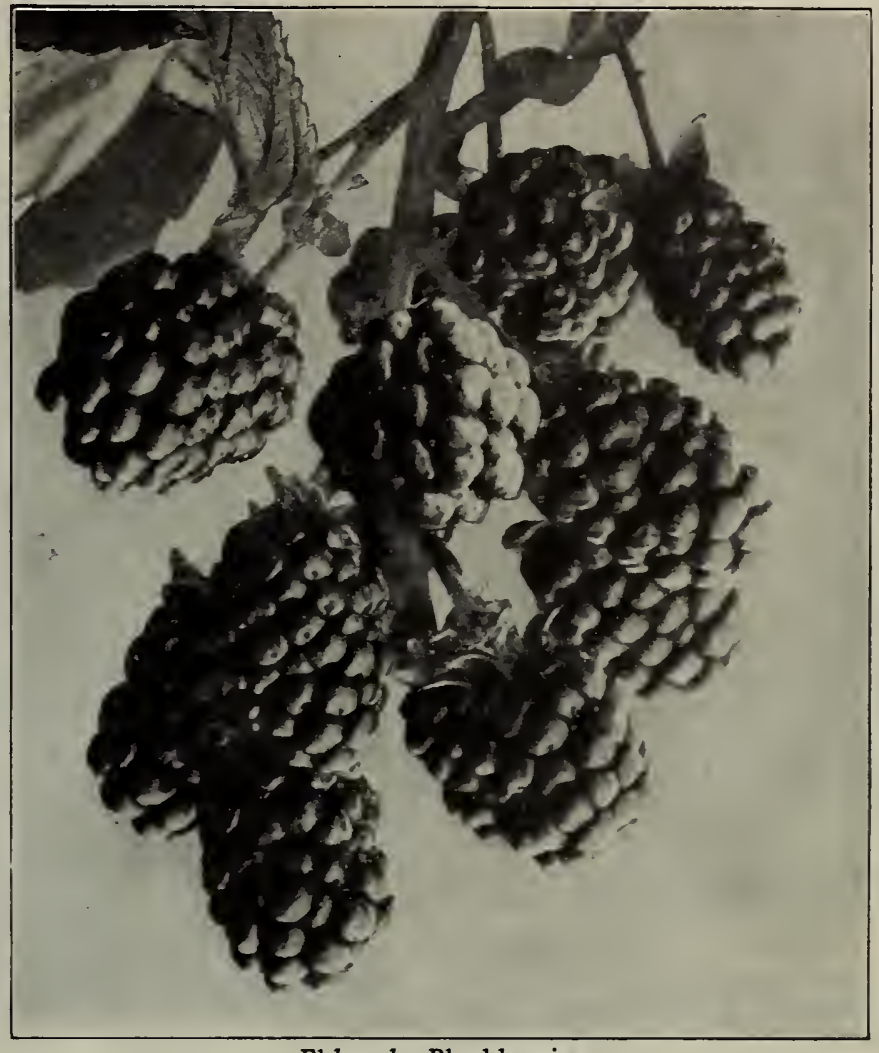

Eldorado Blackberries

Rathbun. Of a large size, resembling Wilson and fully its equal. The berries are sweet, luscious, have no core, are firm enough to ship and handle well. The canes make a strong, erect growth.

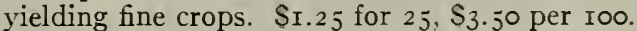

Snyder. Very hardy and wonderfully productive. Berries of medium size, sweet, melting; valuable for cold climates, as it leads where hardiness is a consideration. Early. $75 \mathrm{cts}$. for $25, \$_{2}$ per IOO.

Wilson. Strong-growing, amazingly fruitful. A very superior, large, early berry, of sweet and excellent quality. Very early to ripen. SI for $25, \$_{2} .50$ per 100 .

\section{ASPARAGUS}

Every home with a garden, in the country or city, should have a good-sized bed of Asparagus. Nothing is easier to plant or care for, and its being among the first fruits of the garden makes it a universal favorite. In a commercial way the supply is always inadequate and the price high.

Plant in rows, setting roots I 8 inches apart. Spread the roots out and plant with crown 2 inches below the surface of the ground. Top-dress annually with well-rotted manure.

Strong, two-year plants, $50 \mathrm{cts}$. for 25 , \$I per 100, \$8 per I,000

Donald's Elmira. Produces thick, green stocks of the finest quality, very tender and brittle. Surpasses all others in size, color and yield. You will make no mistake in planting this very pop-

Conover's Colossal. Of a fine quality, tender and highly flavored, and often ready to cut the

Palmetto. Some years it is on the market ten days before the other sorts. Sells at top prices, on account of the great size and beautiful appearance of its stock.

\section{RHUBARB, or PIE PLANT}

Ranks among the very best of the early products of the garden. After the long, dreary months it furnishes the first material for fine pies and delicious table sauce.

To produce tender and quick growth, the ground must be kept very rich.

$$
\text { Strong, healthy roots, } 35 \mathrm{cts} \text {. for } 5,50 \mathrm{cts} \text {. for ro }
$$

Linnæus. Stalks large, tender, juicy; produced quite early.

Queen. Delicious for canning or cooking. The extra-large, tender stalks are a decided pink; a very strong-growing sort. 


\section{STRAWBERRIES}

The Strawberry is undoubtedly the most highly esteemed of all small fruits. It is the first fruit of the season, and the quickest to come into bearing after planting. If well fertilized and cultivated it is a good bearer in almost any soil.

Set plants $\mathrm{I} 2$ to $\mathrm{I} 8$ inches apart, in rows $2 \frac{1}{2}$ feet apart. Mulch well in the fall after the ground has frozen, and then, just before growth starts in the spring, remove the mulch to the edge of the rows. This will keep the ground moist during the fruiting season, and also the berries bright and clean, and will add to their value.

Always plant Strawberries in the spring, for when planted in the fall they seldom do well.

Varieties marked (Imp.) are pistillate or imperfect-flowering. Those marked (Per.) are staminate or perfect-flowering sorts. Imperfect-flowering sorts are the heaviest bearers, if planted near the perfect-flowering sorts. We mix perfect and imperfect bloomers in small orders.

Strong, well-rooted plants, $50 \mathrm{cts}$. for

25, \$I per I00, \$6 per I,000

Aroma. (Per.) Plants are very strong, vigorous, and yield immense crops of large, round, dark glossy red berries of excellent quality and very high flavor.

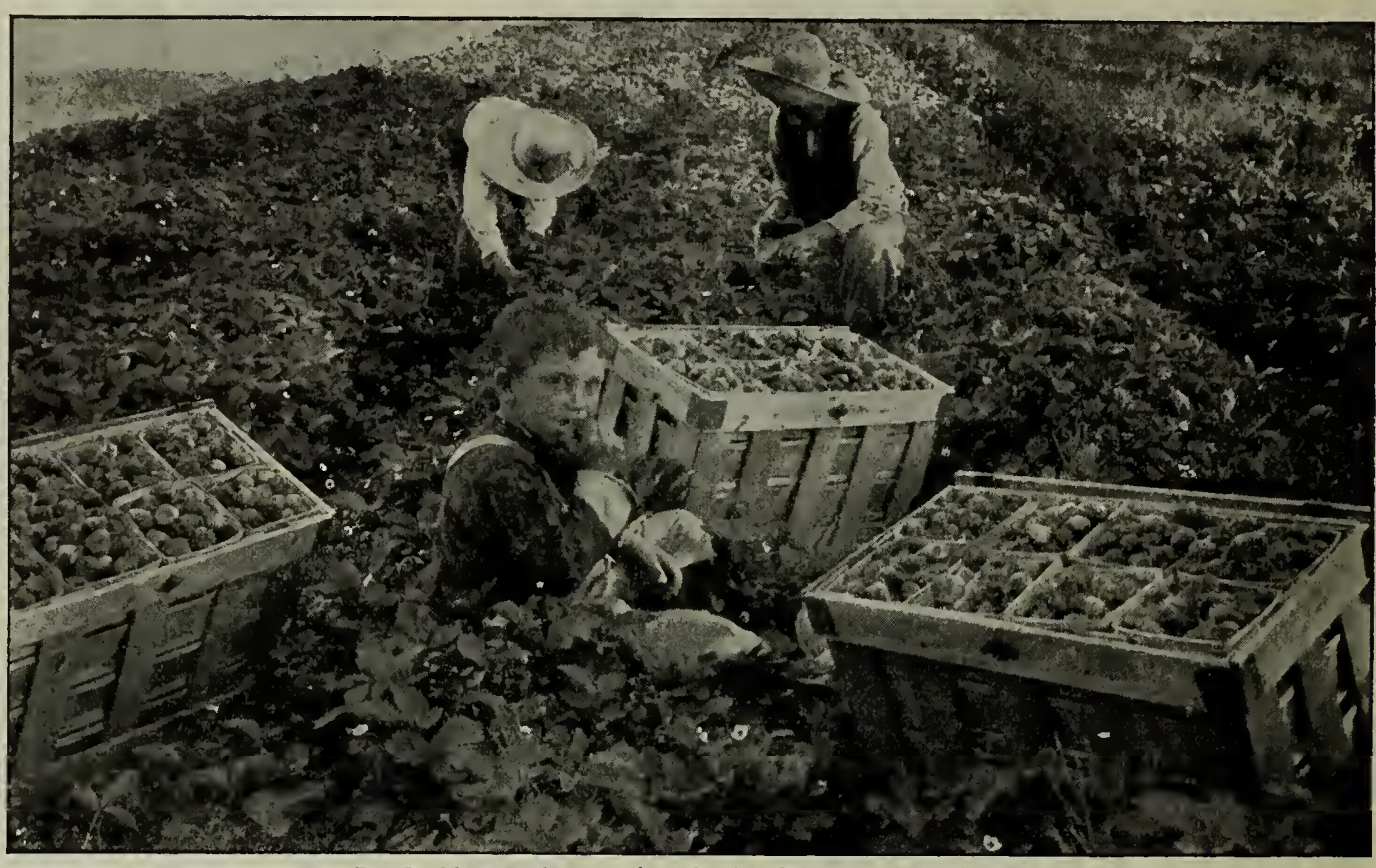

Profitable results can be obtained from a few plants

Brandywine. (Per.) Berries very large, broad heart-shaped; bright red to center; firm-fleshed and finely flavored. One of the very reliable fruiting sorts that can be depended upon for heavy crops on a variety of soils. A valuable late berry.

Bubach. (Imp.) A sterling old sort that combines many excellent qualities; large and uniform in size, rich color and quality, extraordinary vigor and fruitfulness. Fine foliage that endures

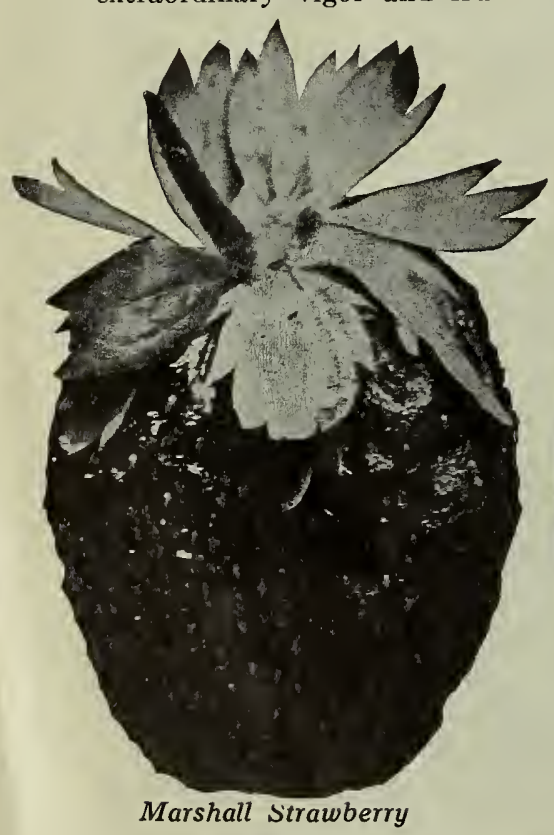
the hottest sun. Season early.

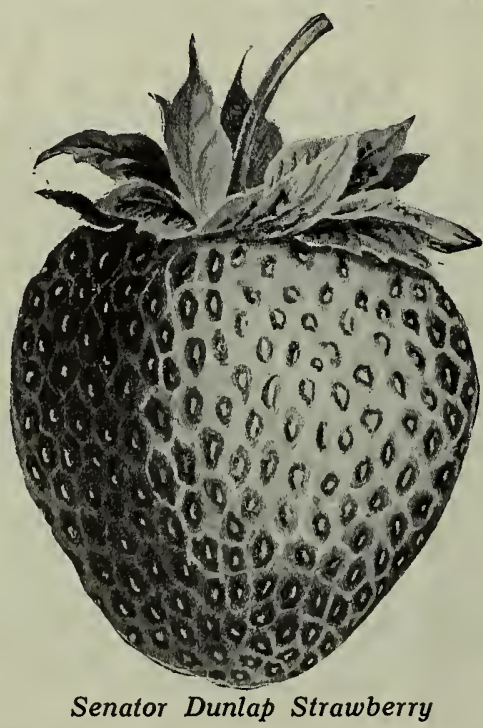

Cardinal. (Per.) From all places where it has been tested comes nothing but words of the highest praise. A late introduction which has leaped into popular favor by the sheer force of its intrinsic merits. It is of a very brilliant scarlet, exceedingly large and of the sweetest, most delicate flavor. It is one of the most prolific berries grown, and a remarkably good shipper.

Gandy. (Per.) The best shipping, long-keeping Strawberry, as late as the latest of the well-tested sorts. Large and firm berries, of uniform size and shape. On heavy, rich loams is a marvel of vigor and fruitfulness.

Haverland. (Imp.) Pollinated with some highly productive, perfect-flowering sorts, it yields enormous crops of superb berries. Early and one of the most valuable market sorts. Very productive of medium to large, conical berries that are smooth, regular, mildly subacid.

Marshall. (Per.) With high culture, the strong, healthy plants produce great crops. Berries very large, handsome, highly colored; of extra quality. Early.

Senator Dunlap. (Per.) One of the very early sorts, and continues in bearing nearly a month. An attractive berry, deep red in color and exceedingly firm in substance and excellent in quality.

Sample. (Imp.) A money-maker for the marketman, and destined to become one of the standard sorts for all sections. A strong plant that succeeds well on nearly all soils and yields astonishing crops of uniformly large, fine berries, pointed, conical, rich scarlet, firm and of fair quality. It is being planted in immense quantities.

Warfield. (Imp.) Great beauty, firmness, earliness, productiveness and vigor make this berry most popular.

Wm. Belt. (Per.) The plant is strong, healthy and very fruitful. Berries very large, conical, bright red, of good flavor. Has taken its place in many localities for home and market.

\section{SMALL-FRUIT COMBINATION, 41 PLANTS FOR \$2}

I6 RASPBERRIES-5 Kansas, 5 Gregg, 5 Cuthbert, I St. Regis (The Everbearer).

\footnotetext{
I5 BLACKBERRIES-5 Ancient Briton, 5 Eldorado, 5 Erie. 5 CURRANTS-2 Fay's Prolific, 5 GRAPES-2 Concord, 2 Niagara,
2 White Grape, x Cherry.
} 


\section{Ornamental Department}

A home without its trees and flowers presents a quite desolate appearance indeed. We all appreciate a beautiful lawn, properly planted with trees, shrubbery, vines and flowers. Whether you are the owner of a contracted city lot, or of the broad extended grounds of a country home, do not overlook the fact that the planting of a few well-selected trees and plants will not only make your home more homelike, but will also greatly increase the value of your property.

\section{DECIDUOUS TREES}

In making one's selection of ornamental trees, the need of variety must be emphasized. For street and avenue planting there are the dense green-foliaged trees. For backgrounds and screens there are the evergreens of so great variety of hue and habit. To give contrast and continued brightness there are the trees of gaily colored foliage. To produce a bright, cheery aspect in winter there are the trees of beautiful bark and brightly colored berries.

Let us help you make your selection. The descriptions herein are, by necessity, short. However, we are always glad to give full and detailed information to all who are interested. We solicit your inquiries.

NOTE.-Special quotations by letter on all large-sized orders or on trees of larger size than quoted

ASH, American White (Fraxinus Americana). Our handsome, broad-headed native Ash. Grows to a great height, having a straight, clean trunk, smooth, gray bark and glossy leaves. Very ornamental as a park, street or lawn tree. 6 to $8 \mathrm{ft}$. $50 \mathrm{cts}$., 8 to ro $\mathrm{ft} .65 \mathrm{cts}$.

European $(F$. excelsior). Somewhat smaller and more spreading than the American Ash, with short, thick trunk and darker foliage. 6 to $8 \mathrm{ft}$. $50 \mathrm{cts}$., 8 to ro $\mathrm{ft} .65 \mathrm{cts}$.

BEECH, Purple-leaved (Fagus purpurea). A most elegant tree for the lawn, as its beautiful, purplish red foliage produces a marked contrast when planted in connection with other trees. 3 to $4 \mathrm{ft}$. $90 \mathrm{c}$.

BIRCH, European White (Betula alba). Quite erect when young, its branches begin to droop gracefully with age. Its bark is snowy white and very effective in landscape work. 4 to $6 \mathrm{ft} .75 \mathrm{cts}$.

Purple-leaved ( $B$. purpurea). A variety possessing all the vigorous habits of the Birch, with purple foliage. 5 to $6 \mathrm{ft}$. \$I.

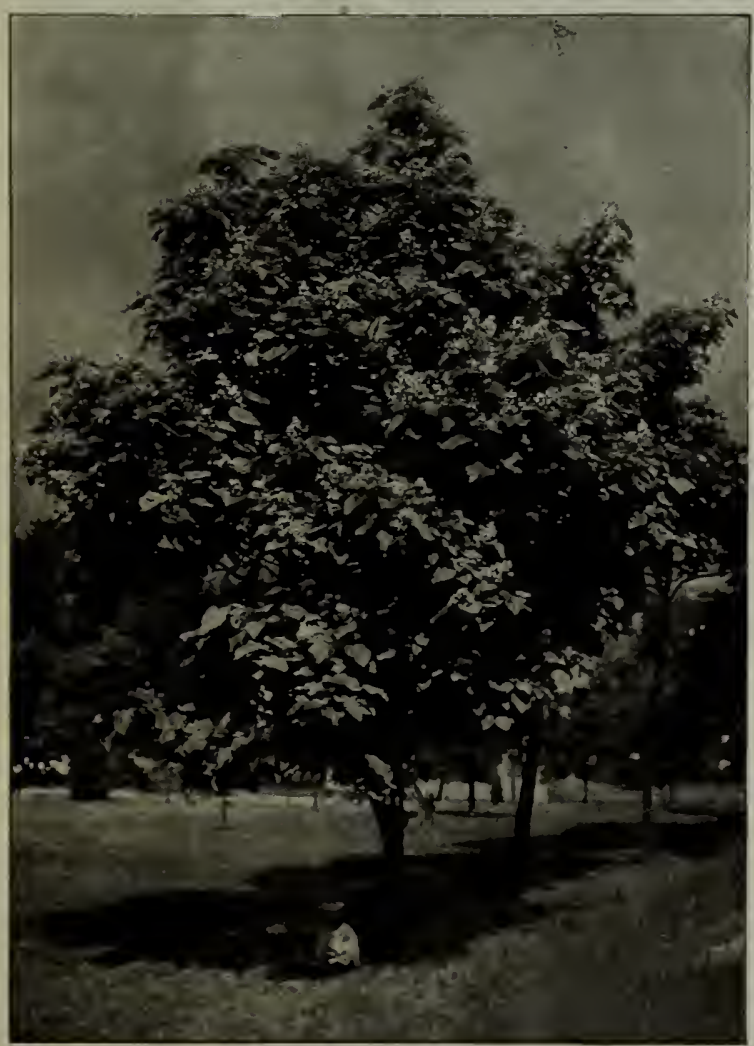

Catalpa speciosa

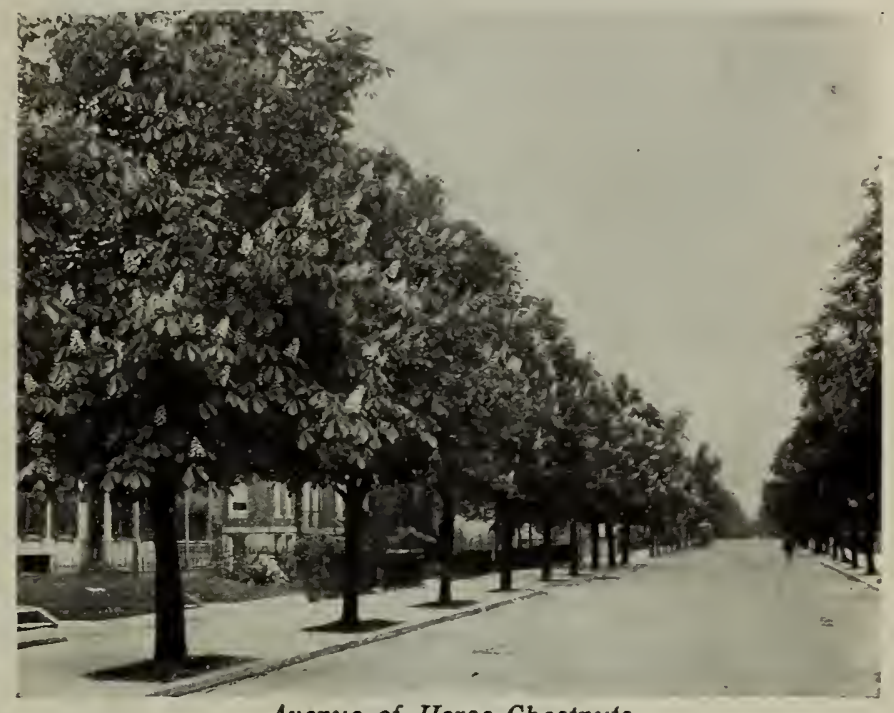

Avenue of Horse-Chestnuts

CATALPA Bungei (Chinese Catalpa). A remarkable species, forming a dense, round head. Creates a most unique effect on the lawn. 6-to 8-foot stems \$r, 8- to ro-foot stems SI.25. speciosa (Western Catalpa). We recommend this for planting where quick shade is desired, as it is a rapid grower and a very shapely tree. Especially ornamental in June when it is laden with beautiful white flowers in large, showy panicles. 6 to $8 \mathrm{ft} .30 \mathrm{cts} ., 8$ to ro ft. $40 \mathrm{cts}$.

CRAB, Bechtel's Double-flowering (Pyrus angustifolia). Tree of moderate size, covered in early spring with large, beautiful, double, fragrant flowers of a delicate pink. From a distance the flowers resemble small roses. Blooms quite young. One of these beautiful, little, shrub-like trees should be planted on every lawn. 3 to $4 \mathrm{ft} .6_{5} \mathrm{cts}$.

DOGWOOD, White-flowering (Cornus florida). Flowers white, 3 to $3^{\mathrm{T}} / 2$ inches in diameter, produced in early spring before the leaves appear. The bright red young growth makes this shrub-like tree very attractive in winter; very hardy. 2 to $3 \mathrm{ft}$. 50 cts.

ELM, American (Ulmus Americana). One of the grandest of our native trees. Its lofty growth and graceful, drooping branches make it a universal favorite. 6 to $8 \mathrm{ft}$. $60 \mathrm{cts}$., 8 to ro $\mathrm{ft}$. $70 \mathrm{cts}$.

Scotch $\left(U^{\prime}\right.$. scabra). Of lofty growth, smaller foliage and less drooping habit than the American. 6 to $8 \mathrm{ft}$. $60 \mathrm{cts}$., 8 to ro $\mathrm{ft}$. $70 \mathrm{cts}$.

HORSE-CHESTNUT, White-flowering (Esculus Hippocastanum). This well-known species forms a large-sized tree, of handsome, regular outline. In May it is covered with magnificent, erect spikes or panicles of white flowers lightly marked with red. 5 to $6 \mathrm{ft} .65 \mathrm{cts}$.

Double White-flowering ( $E$. Hippocastanum $f l$. pl.). A superb variety, with double flowers, in larger panicles than the common sort. Has no fruit to litter up the ground. 4 to $5 \mathrm{ft}$. SI.

Red-flowering ( E. rubicunda). Form round; flowers showy red, blooming a little later than the white, leaves a deeper green. Contrasts well when planted with the white-flowering. 4 to $5 \mathrm{ft}$. S 1.25 .

JUDAS TREE, or Red Bud (Cercis Canadensis). A small-growing tree, of irregular form and heart-shaped leaves, covered with delicate pink blossoms in early spring before the leaves appear; very ornamental 60 cts.

LINDEN, American (Tilia Americana). A stately tree, the branches inclined to spread and develop into an ample, rounded head where the tree grows in the open. Its freedom from insect pests, handsome foliage and large and fragrant flowers make it a very desirable ornamental tree. 6 to $8 \mathrm{ft}$. 75 cts., 8 to Io $\mathrm{ft} .90 \mathrm{cts}$. 


\section{THE PROGRESS NURSERY COMPANY, TROY, OHIO}

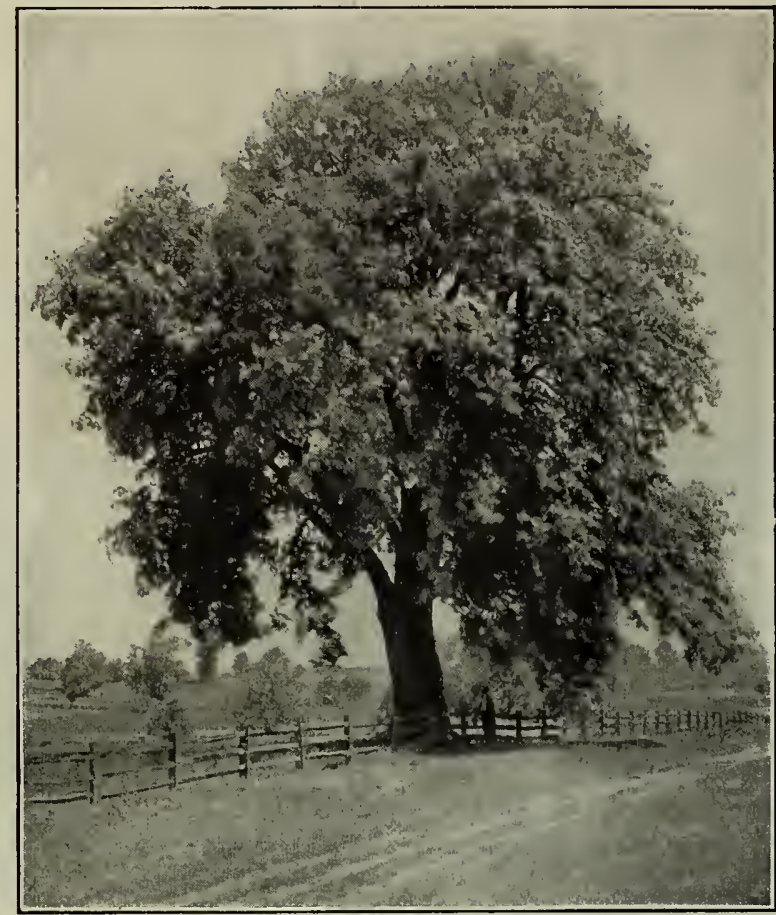

American Linden

Linden, European (Tilia platyphyllos). An excellent, broad-leaved variety, growing into a noble tree, 60 to 80 feet high. Flowers in June. 6 to $8 \mathrm{ft}$. $60 \mathrm{cts}$, 8 to Io $\mathrm{ft}$. $75 \mathrm{cts}$.

MAGNOLIA acuminata (Cucumber Tree). A tall, very rapidgrowing, pyramidal tree. In midsummer large, creamy white blossoms appear among its deep green leaves, and large, cucumber-shaped fruits, that turn bright crimson, succeed them. 5 to $6 \mathrm{ft}$. $60 \mathrm{cts}$.

Soulangeana. In growth it is more like a large shrub. One of the hardiest and finest of foreign Magnolias. Its blossoms are 3 to 5 inches across; cup-shaped, white and rosy violet, and comes into full bloom early in the spring before the leaves appear. $3 \mathrm{ft} . \$ 2$.

Speciosa. Flowers of this variety are a trifle smaller and of lighter color than the Soulangeana, blooming about a week later and remaining perfect on the tree for a longer time. Tree of the same habit. $3 \mathrm{ft}$. $\$ 2$.

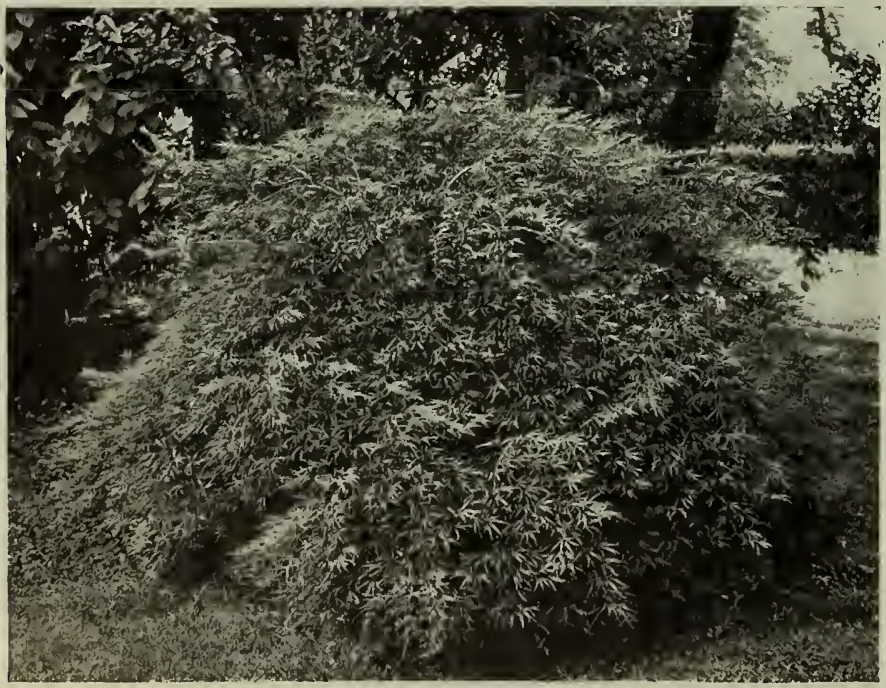

Japanese Maples

\section{MAPLE · Acer}

The Maple in its many varieties is the most widely planted tree of the day, and justly so. For streets, avenues and other places where shade is required, the Silver, Ash-leaved, Norway and Sugar are invaluable. There are no more beautiful lawn species than Wier's Cut-leaved or the Schwedleri.

Ash-leaved, or Box Elder. A native tree of irregular, spreading habit. Maple-like in seed and Ash-like in foliage. A rapid grower, which makes it very valuable where quick shade is desired. 6 to $8 \mathrm{ft} .40 \mathrm{cts} ., 8$ to ro ft. $50 \mathrm{cts}$.

Japanese (Acer polymorphum). There is not a dwarf tree in cultivation that can compare to the Japanese Maples for grace and beauty. They grow best in partially shaded situations and in well-drained soil. Rarely over to feet high, and there is nothing better for a hardy, permanent bed of color. Very often used to give variety to the shrubbery planting, as they hold their color all summer. Full description of sizes and colors by letter. 2 to 3 ft. $\$ 3$.

Norway (A. platanoides). Sturdy, compact, vigorous, it is one of the very best trees for lawns, parks and gardens. A handsome tree of fairly rapid growth, forming a dense, rounded head of strong branches and broad, deep green leaves, which turn to beautiful shades of golden yellow in fall. The most widely planted ornamental tree, and always beautiful, giving a dense, deep shade. 6 to $8 \mathrm{ft}$. $75 \mathrm{cts}$., 8 to ro $\mathrm{ft} .90 \mathrm{cts}$.

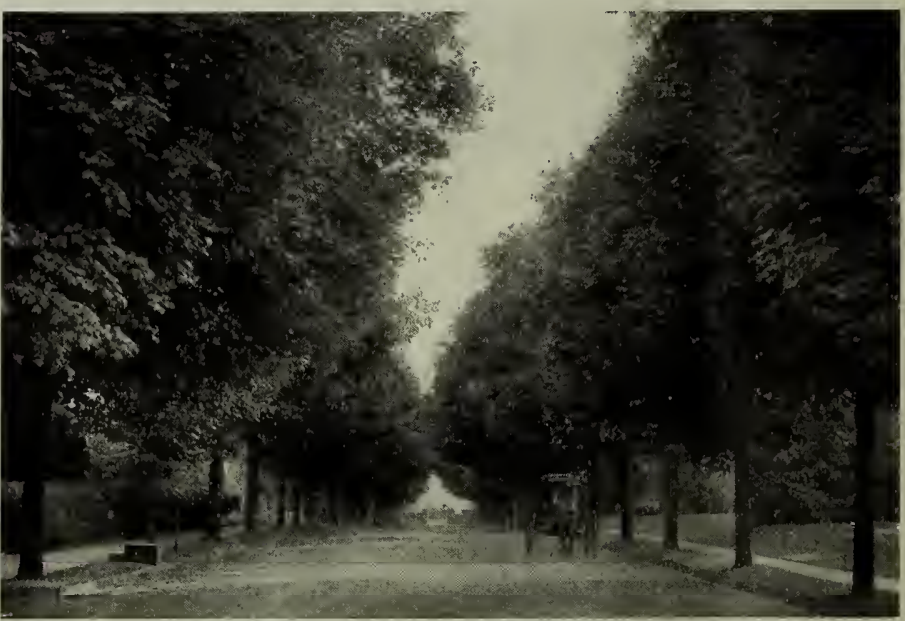

Avenue of Norway Maples

Schwedleri (Purple-leaved Norway). Of the same growth and habit as the Norway, with bright crimson foliage in early spring, which gradually changes to a purplish green later in the season. At least one of these beautiful specimens should appear on every lawn. 6 to $8 \mathrm{ft} . \$ \mathrm{r}, 8$ to ro $\mathrm{ft}$. $\$ \mathrm{I} .25$.

Silver-leaved (A.dasycarpum). A very quick grower. Trimmed moderately, it becomes of very fine shape. Certainly a very beautiful ornamental tree if given room to develop. Valuable where quick shade is desired, and grows to a good size. 6 to $8 \mathrm{ft}$. $40 \mathrm{cts}$., 8 to Io ft. $50 \mathrm{cts}$.

Sugar, or Rock (A. saccharum). One of the most desirable of all ornamental trees, being very stately in growth, of fine form and beautiful foliage. Especially valuable for avenue planting. 6 to $8 \mathrm{ft} .75 \mathrm{cts} ., 8$ to ro ft. $\$$ r.

Wier's Cut-leaved. This remarkably beautiful tree has a partly drooping habit and finely divided leaves. A rapid grower and an excellent lawn trec, particularly for a small place. 6 to $8 \mathrm{ft}$. $60 \mathrm{cts} ., 8$ to Io $\mathrm{ft} .75 \mathrm{cts}$.

MOUNTAIN ASH, European (Sorbus Aucuparia). A very beautiful lawn tree, with smooth bark and dense, regular head, laden in winter with large clusters of bright red berries. 4 to $6 \mathrm{ft}$. $50 \mathrm{cts}$., 6 to $8 \mathrm{ft} .65 \mathrm{cts}$.

Oak-leaved (S. quercifolia). Of the same fine habit, but with dark, lobed leaves, downy underneath. 4 to $6 \mathrm{ft} .75 \mathrm{cts}$. 


\section{DECIDUOUS TREES, continued}

OAK, White (Quercus alba). One of the largest-growing Oaks, forming a wide-spreading head when fully developed. The foliage takes on a light purplish hue in late autumn. 4 to $6 \mathrm{ft}$. 85 cts.

Mossy Cup, or Bur (Q. macrocarpa). Of massive, open growth, with large, heavy leaves and deeply corrugated bark. 4 to $6 \mathrm{ft}$. $85 \mathrm{cts}$.

Pin (Q. palustris). Foliage deep green and finely divided. As the tree grows, the lower branches droop until they almost touch the ground. A splendid lawn tree. Thrives in any soil. 4 to 6 ft. 75 cts.

Scarlet ( $Q$. coccinea). A grand, round-topped tree, with bright green, deeply cut leaves that change to sparkling scarlet in the fall. 4 to $6 \mathrm{ft} .85 \mathrm{cts}$.

PLUM, Purple-leaved (Prunus Pissardi). A small-sized, elegant tree with rich purple leaves, ends of shoots brilliant red. Very desirable in lawn planting for contrast, as it holds its color well all summer. 3 to $4 \mathrm{ft}$., $40 \mathrm{cts}$.

POPLAR, Lombardy. Being of a high, spire-like growth, it is a favorite in landscape work for breaking the monotony of lower, round-top trees. Leaves glossy green above, silvery beneath. 6 to $8 \mathrm{ft}$. $50 \mathrm{cts}$., 8 to ro $\mathrm{ft} .65 \mathrm{cts}$.

Carolina. While we do not recommend the extensive planting of Carolina Poplar, it is very desirable where quick shade is needed. However, if it is well pruned back the first few seasons, it makes a strong, durable growth. 6 to $8 \mathrm{ft}$. $30 \mathrm{cts}$., 8 to Io $\mathrm{ft}$. 40 cts.

SYCAMORE, American (Platanus occidentalis). Very effective in winter, when its branches show almost as white as the birch, and its mottled trunk of gray, green and brown is revealed. Broad-spreading, massive and picturesque; of ten grows to $100 \mathrm{feet}$, and is a fine street tree. 6 to $8 \mathrm{ft}$. $60 \mathrm{cts}$., 8 to Io ft. 75 cts.

European ( $P$. orientalis). One of the oldest cultivated trees, and among the best for street and avenue planting. Grows rapidly to grand size, is bold, picturesque, hardy, healthy and vigorous in all soils. Has large, leathery, clean-cut leaves. 6 to $8 \mathrm{ft}$. $60 \mathrm{cts} ., 8$ to ro $\mathrm{ft} .75 \mathrm{cts}$.

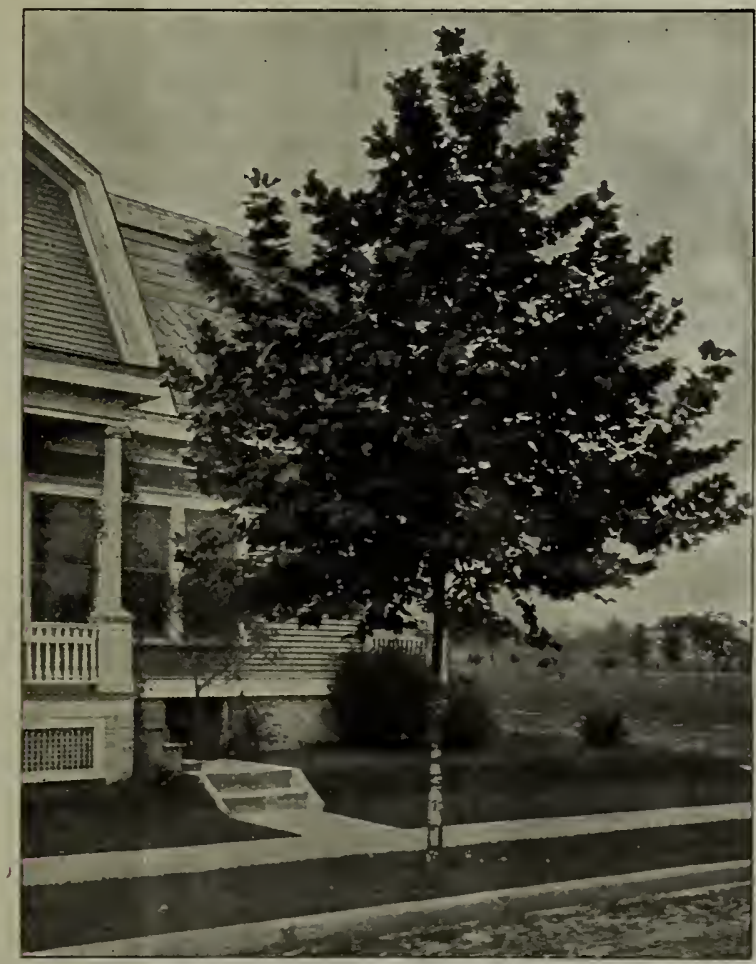

European Sycamore

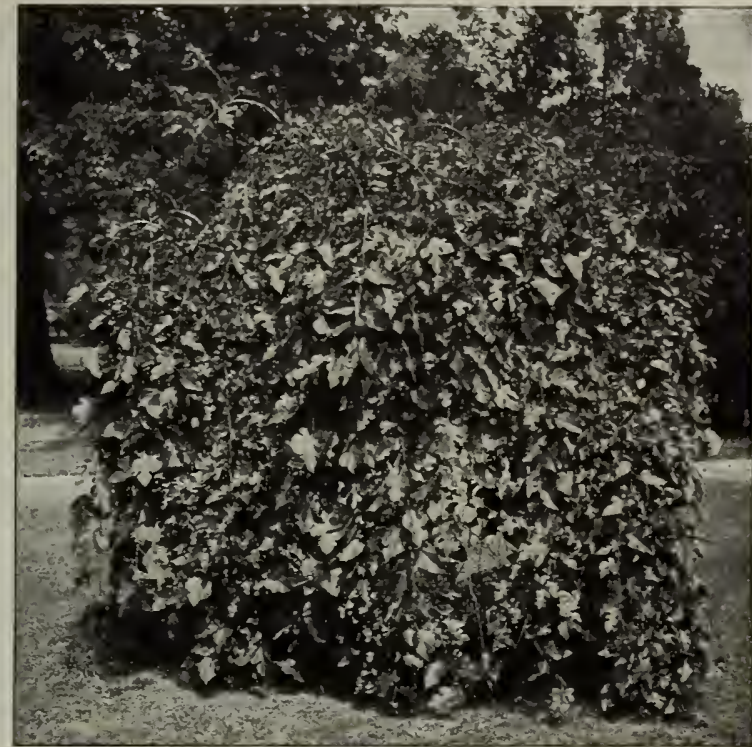

Teas' Weeping Mulberry

TULIP TREE (Liriodendron tulipifera). A tall, magnificent native tree, of rapid, pyramidal growth. Valued for its smooth, clean bark and handsome green foliage. Flowers appear the first of June. They are large, greenish yellow, blotched orange, and of the same shape as the tulip. Makes a most desirable tree for the lawn. 4 to $6 \mathrm{ft}$. $50 \mathrm{cts}$., 6 to $8 \mathrm{ft}$. $60 \mathrm{cts}$.

WILLOW, Laurel-leaf (Salix laurifolia). A beautiful, distinct, medium-sized tree, with shining, laurel-like leaves that make it very conspicuous in the sunshine. Has bright green bark. May be clipped into form or left bushy. 6 to $8 \mathrm{ft}$. 40 cts.

Gold-barked ( $S$. vitellina aurea). A showy variety, with golden bark, making it very attractive in the winter. 6 to $8 \mathrm{ft}$. $60 \mathrm{cts}$.

\section{TREES OF DROOPING HABIT}

ASH, Mountain Weeping. Grafted on tall stems, this tree spreads into a beautiful green tent of shade. Used extensively in landscape work. $6 \mathrm{ft}$. $75 \mathrm{cts}$.

BIRCH, Cut-leaved Weeping. A tree of wonderful grace and beauty. Tall, vigorous, with slender, drooping branches; foliage colors brilliantly in fall, and its bare white trunk and branches are very beautiful in winter. 6 to $8 \mathrm{ft}$. Si.

ELM, Camperdown Weeping. One of the finest weeping trees, with horizontal limbs and long, pendulous branches. Si.

MULBERRY, Teas' Weeping. One of the hardiest and most beautiful of the weeping trees. Grafted on a straight stem, 5 feet high, its slender, drooping branches may be trimmed in almost any shape. Si.

WILLOW, Babylonica Weeping. Most familiar and beautiful of all Willows. One of the finest of all drooping trees. 4 to $6 \mathrm{ft}$. $50 \mathrm{cts}$.

Kilmarnock Weeping. Beautiful ornament on the lawn and bears the dainty "pussy-willows" so much sought for in the spring. Grafted on 5 -foot stems, 75 cts.

\section{DANDY SHRUB COLLECTION, $\$ 1.20$}

I Althæa, or Rose of Sharon I Spiræa Van Houttei

I Calycanthus (Sweet- I Symphoricarpos racemosus scented Shrub)

I Hydrangea paniculata (Japan Snowball) grandiflora

All plants will be strong, two years old, and 2 to 3 -feet higb 


\section{DECIDUOUS ORNAMENTAL SHRUBBERY}

By a careful choice of shrubbery, not only a continuous succession of bloom of varied tint and form is secured throughout the entire summer, but the foliage will present a great variety of riotous color in its many shades of yellow, white, gray, purple and green. In winter very beautiful effects are produced by the many-colored twigs and berries. Nothing can set off a lawn or hide some unsightly object or break the outline of foundation walls so completely as shrubbery planted singly and in masses.

Take advantage of our knowledge of ornamental shrubbery, for we are sure we can make suggestions that will be of help to you in making your planting.

ALTHÆA (Rose of Sharon). Very fine, free-blooming shrubs of the easiest culture. Very desirable on account of blooming in August and September in such rich profusion, and showing such a diversity of color, when scarcely any other tree or shrub is in blossom. Very showy if planted as a hedge. Colors: Double Red, Rose, Purple, Blue, White, Striped and Variegated-leaved. 2 to $3 \mathrm{ft} .25 \mathrm{cts}$. each, $\$ 2$ for 10.

CALYCANTHUS (Sweet-scented Shrub). One of the most desirable shrubs. The wood is scented, the foliage rich, and flowers of a rare chocolate-color, having a peculiar, delightful odor. Blooms in June. 2 to $3 \mathrm{ft}$. $25 \mathrm{cts}$. each, $\$ 2$ for ro.

CORNUS Sibirica (Dogwood). Grows 6 to Io feet high, with clusters of fine, white flowers, succeeded by a fall crop of ornamental berries. Branches turn to blood-red during winter. 2 to $3 \mathrm{ft}$. $25 \mathrm{cts}$. each, $\$ \mathrm{I}$ for 5 .

Stolonifera (Red Osier Dogwood). A rather dwarf form of the Dogwood. Bark red, flowers white, followed by pure white berries. 2 to $3 \mathrm{ft} .25 \mathrm{cts}$. each, $\$$ I for 5 .

DEUTZIA crenata. Grows 6 to 8 feet high, becoming a perfect mass of white bloom in June. May be planted as specimens, in groups, or used as background for other shrubbery. 2 to $3 \mathrm{ft}$. $20 \mathrm{cts}$. each, $\$ \mathrm{I} .75$ for IO.

Candidissima. Another of the high-growing Deutzias. A very shapely bush. Flowers double, white. 2 to $3 \mathrm{ft}$. $20 \mathrm{cts}$. each, $\$ 1.75$ for IO.

Gracilis. A species of charming habit, rarely growing over 2 feet high. Its slender, drooping branches are wreathed with pure white flowers in early June. I 8 to 24 in. $30 \mathrm{c}$. each, $\$ 2.5$ o for Io.

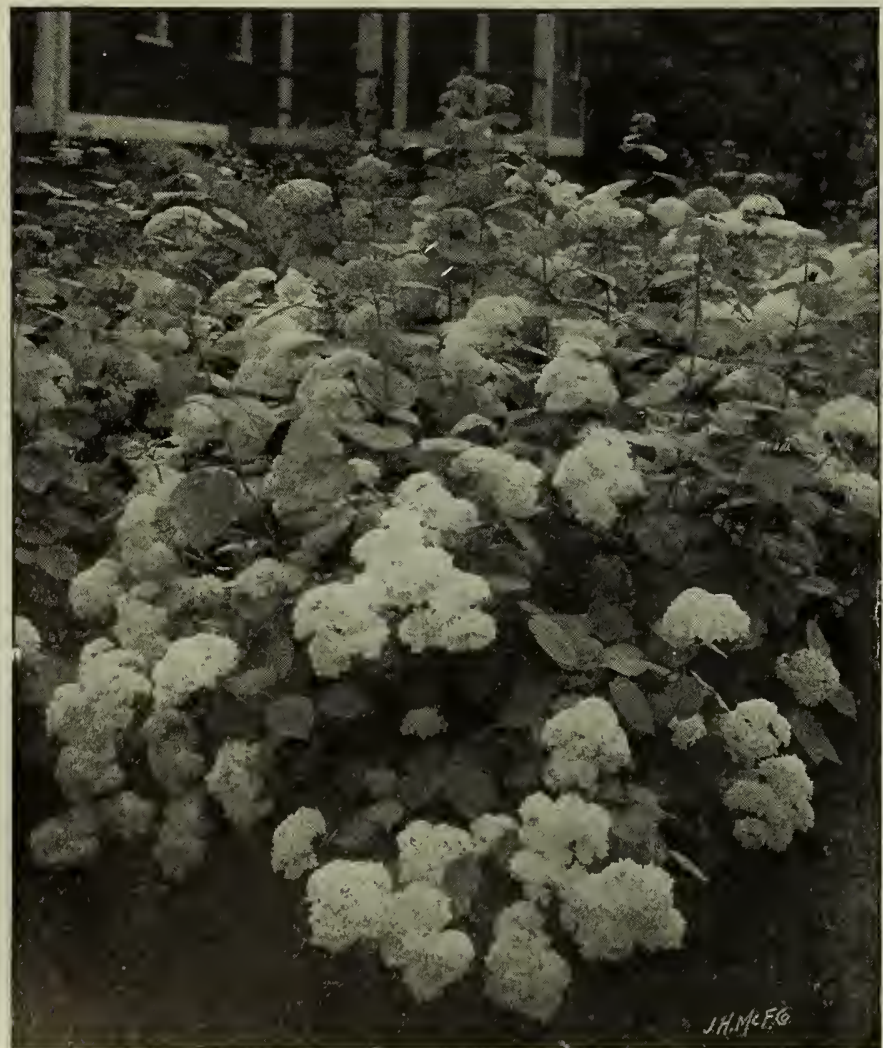

Hydrangea arborescens grandiflora
Deutzia Lemoinei. Flowers of pure white, borne on stout branches of upright growth. Of dwarfish habit and a free bloomer. 18 to 24 in. $25 \mathrm{cts}$. each, $\$$ I for 5 .

Pride of Rochester. A very showy, large-flowered sort that blooms profusely very early in the season. 2 to $3 \mathrm{ft} .25 \mathrm{cts}$. each, \$I for 5 .

EXOCHORDA grandiflora (Pearl Bush). A compact, hardy shrub growing from 6 to ro feet high; can be trimmed to any desired shape. Flowers borne in May, in slender racemes of eight to ten florets each. 2 to $3 \mathrm{ft}$. $25 \mathrm{cts}$. each, $\$ 2$ for Io.

FILBERT, Purple-leaved (Corylus Avellana). A very conspicuous shrub of the Hazel family, having large, dark purple leaves. Appears to fine advantage planted either as single specimen or in groups with other shrubbery, the leaves holding their color well. I 8 to 24 in. 50 cts.

FORSYTHIA Fortunei (Golden Bell). Of upright growth, dark green leaves and bright golden yellow flowers appearing very early in the spring. 2 to $3 \mathrm{ft} .25 \mathrm{cts}$., $\$ 1.80$ for Io.

Viridissima. Of the same habits as the Fortunei, except that the flowers are a little deeper yellow and somewhat twisted. 2 to $3 \mathrm{ft}$. $25 \mathrm{cts}$. each, $\$ \mathbf{I} .80$ for 10.

HYDRANGEA arborescens grandiflora. Blooms are of very large size and pure white. Its most valuable characteristic is its coming into bloom just after the passing of the early spring flowers, and its long season of bloom, from June to August, makes it doubly valuable to the owner of any garden. 2 to $3 \mathrm{ft}$. 30 cts. each, $\$ 2.50$ for Io.

Paniculata grandiflora. Probably no other shrub is more frequently met with on lawns and in dooryards, and it justly merits its wide popularity. Of strong, spreading habit, with large, terminal panicles of pure white flowers in August, that change to a pinkish hue in September. Sometimes grown as a tree. 2 to $3 \mathrm{ft} .25 \mathrm{cts}$. each, $\$ 2$ for Io; 3 to $4 \mathrm{ft}$., tree form, $75 \mathrm{cts}$.

KERRIA Japonica (Globe Flower). A slender, green-barked shrub, with large, rich, globular, yellow flowers which resemble small cactus dahlias, blooming from July to October. 2 to $3 \mathrm{ft}$. $25 \mathrm{cts}$., each $\$ 2$ for Io.

\section{BUSH HONEYSUCKLE • Lonicera}

LONICERA fragrantissima. This Chinese shrub is greatly valued for its exceedingly sweet-scented, pinkish white flowers, which appear in the earliest days of spring. In sheltered situations it retains its dark green leaves nearly all winter. 2 to $3 \mathrm{ft} .25 \mathrm{cts}$. each, $\$ 2$ for Io.

Morrowi. A fine variety from Japan; very attractive in early spring on account of its pure white flowers, but is valued chiefly for the brilliant red fruit that appears in the fall. 2 to $3 \mathrm{ft} .25 \mathrm{cts}$. each, $\$ 2$ for Io.

Tatarica. Its pink flowers in late spring contrast beautifully with its bright green foliage, but its chief charm is its wealth of orange and red berries in autumn. 2 to $3 \mathrm{ft} .25 \mathrm{cts}$. each, \$2 for IO.

PHILADELPHUS coronarius (Garland Syringa). A well-known and highly esteemed shrub, with pure white, highly scented flowers, which blossom very early in graceful sprays, and have a resemblance to orange blossoms. 2 to $3 \mathrm{ft}$. $25 \mathrm{cts}$. each, $\$ 2$ for 10 .

Coronarius aureus. A very pretty shrub of medium size, with golden yellow leaves, which retain their color throughout the summer and autumn. Very valuable in creating pleasing and striking contrasts with other shrubs. 2 to $3 \mathrm{ft}$. $30 \mathrm{cts}$. each, $\$ 2.50$ for 10 . 


\section{THE PROGRESS NURSERY COMPANY, TROY, OHIO}

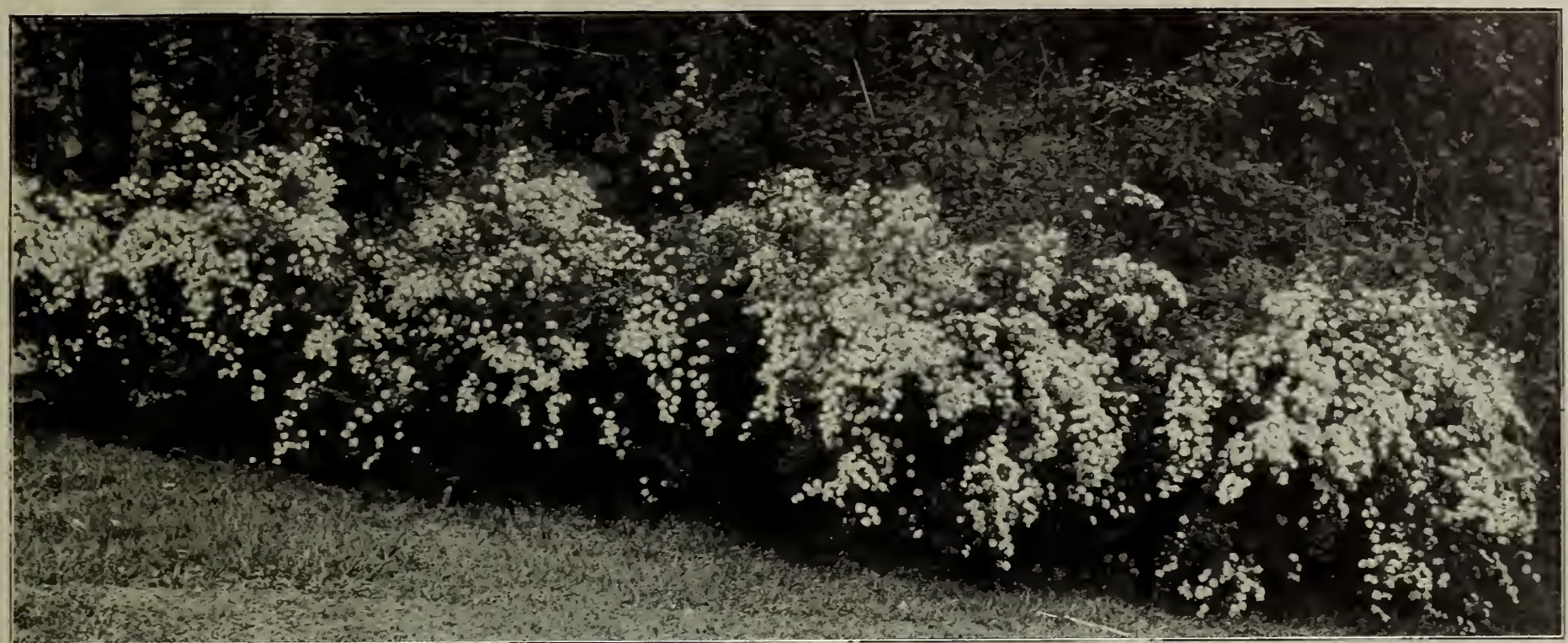

Spiræa Van Houttei

\section{DECIDUOUS SHRUBS, continued} SAMBUCUS Canadensis (American Elder). A most hardy shrub,
and largely used for backgrounds in ornamental planting, where it creates a very pleasing effect, having beautifully cut leaves, pleasing flowers in June, followed by rich, dark red berries. 2 to $3 \mathrm{ft} .25 \mathrm{cts}$. each, \$2 for 10.

Aurea (Golden Elder). A great favorite, on account of its golden foliage which, when planted with other high-growing shrubbery, forms a marked contrast. Flowers white, in flat-topped cymes. 2 to $3 \mathrm{ft}$. $25 \mathrm{cts}$. each, $\mathrm{S}_{2}$ for 10.

SPIRAA, Anthony Waterer. A very beautiful, dwarf variety, blooming from about the last of June throughout the whole summer, in beautiful clusters of rosy crimson flowers. Useful for edging, mass planting or specimen work. 18 to 24 in. 25 cts. each, \$2 for ro.

Billardii. One of the high-growing Spireas, blooming all summer, in dense panicles of rich pink flowers. 2 to $3 \mathrm{ft}$. $25 \mathrm{cts}$. each, $\$_{2}$ for 10 .

Prunifolia f. pl. (Bridal Wreath). As beautiful as it is popular. In early summer there appear along its slender branches dainty, pure white, very double flowers. Its pretty, glossy green leaves change to crimson and rich purple in autumn. 2 to $3 \mathrm{ft}$. $30 \mathrm{cts}$., each $\$ 2.50$ for 10 .

Van Houttei. A bushy shrub, growing about 5 feet high, with delicate leaves and clusters or panicles of pure white flowers, which bloom along the entire length of the slender, drooping branches in early spring, turning the whole bush to snowy whiteness. Flowers appear before the leaves are fully out. 2 to $3 \mathrm{ft}$. $25 \mathrm{cts}$. each, $\mathrm{S}_{2}$ for 10.

SYMPHORICARPOS racemosus (Snowberry). A most attractive shrub of graceful, drooping habits. Has small pink flowers in July and August, followed by large, pure white, wax-like berries in clusters. Highly valued, as it thrives in dense shaded places where little else will grow. 2 to $3 \mathrm{ft} .25 \mathrm{cts}$. each, $S_{2}$ for 10.

SYRINGA vulgaris (Purple Lilac). Beyond doubt the Lilac is among the most popular of all ornamental shrubs. And this old-fashioned purple variety holds its own against all newcomers with its fine, heart-shaped leaves and splendid panicles of typical Lilac flowers, which are of delightful fragrance and borne in great clusters in May. 2 to $3 \mathrm{ft} .25 \mathrm{cts}$. each, $S_{2}$ for 10.

Vulgaris alba (White Lilac). Similar in growth and habit to the Purple, with pure white flowers. 2 to $3 \mathrm{ft} .25 \mathrm{cts}$. each, $\$_{2}$ for Io.

Tree Lilacs, both Single and Double, in the following colors: Blue, Brilliant Rose, Purple and White. 3 to $4 \mathrm{ft}$. 75 cts. each.
VIBURNUM Opulus (High Bush Cranberry). At very decorative, native shrub, growing 8 to ro feet high, with white flowers in May, followed by beautiful, showy clusters of bright red berries. 2 to $3 \mathrm{ft} .25 \mathrm{cts}$. each, \$2 for 10.

plicatum (Japan Snowball). One of the finest shrubs. Moderate in growth and compact in form, with the branches spreading at right angles, curiously crinkled foliage and large. globular flowers of purest white, produced all over the bush in great abundance. 2 to $3 \mathrm{ft} .35 \mathrm{cts}$. each, $\$_{3}$ for 10.

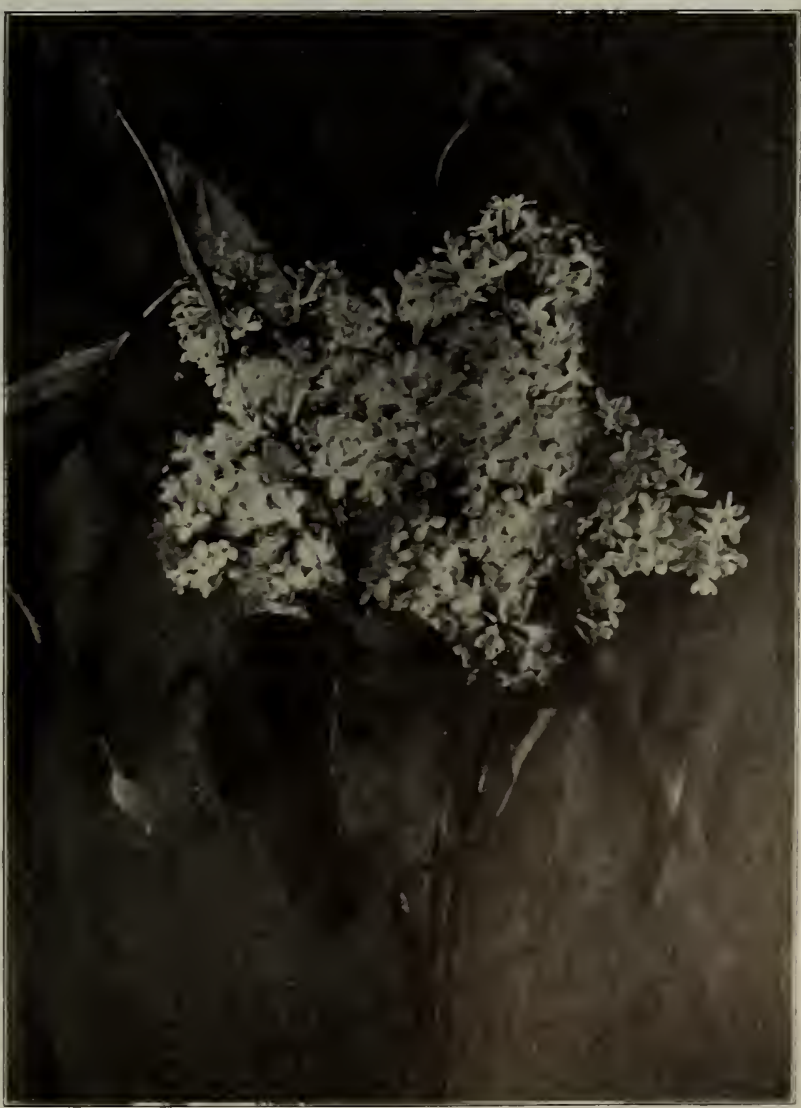

Syringa vulgaris alba (White Lilac) 


\section{THE PROGRESS NURSERY COMPANY, TROY, OHIO}

\section{HARDY SHRUBS, continued}

VIBURNUM Opulus sterile. This is the well-known Snowball of all old-fashioned gardens. Besides the showy white flowers in May, the foliage is very decorative, assuming brilliant hues in the fall. 2 to $3 \mathrm{ft}$. $30 \mathrm{cts}$. each, $\$ 2.50$ for Io.

WEIGELA rosea. One of the most generally cultivated species of Weigela; very free-flowering; of spreading habit and thrives in any soil. 2 to $3 \mathrm{ft}$. $30 \mathrm{cts}$. each, $\$ 2.50$ for ro.

Eva Rathke. Very distinct in color of flower from other variety. A remarkably free bloomer. Flowers are deep crimson, and produced in great abundance. 2 to $3 \mathrm{ft}$. $40 \mathrm{cts}$. each.

Variegated-leaved. Leaves margined with creamy white; flowers pink. Dwarf. Much used for contrastive purposes. I8 to 24 in. 35 cts. each, $\$ 3$ for Io.

\section{HEDGE PLANTS}

BARBERRY. When a low, ornamental hedge is desired, nothing surpasses the Barberry. Either Vulgaris, the common green sort, or Purpurea, the purple-leaved variety, create very beautiful effects. However, Thunbergii is the favorite. Its slender, drooping branches are very completely covered with delicate, bright green leaves which in autumn, take on a brilliant red color followed by bright red berries, which brighten up the entire hedge far into the winter. The Barberries are very luxuriant in growth and graceful in form, they consequently require very little trimming to produce a rich and compact hedge. Plant I 2 inches apart.

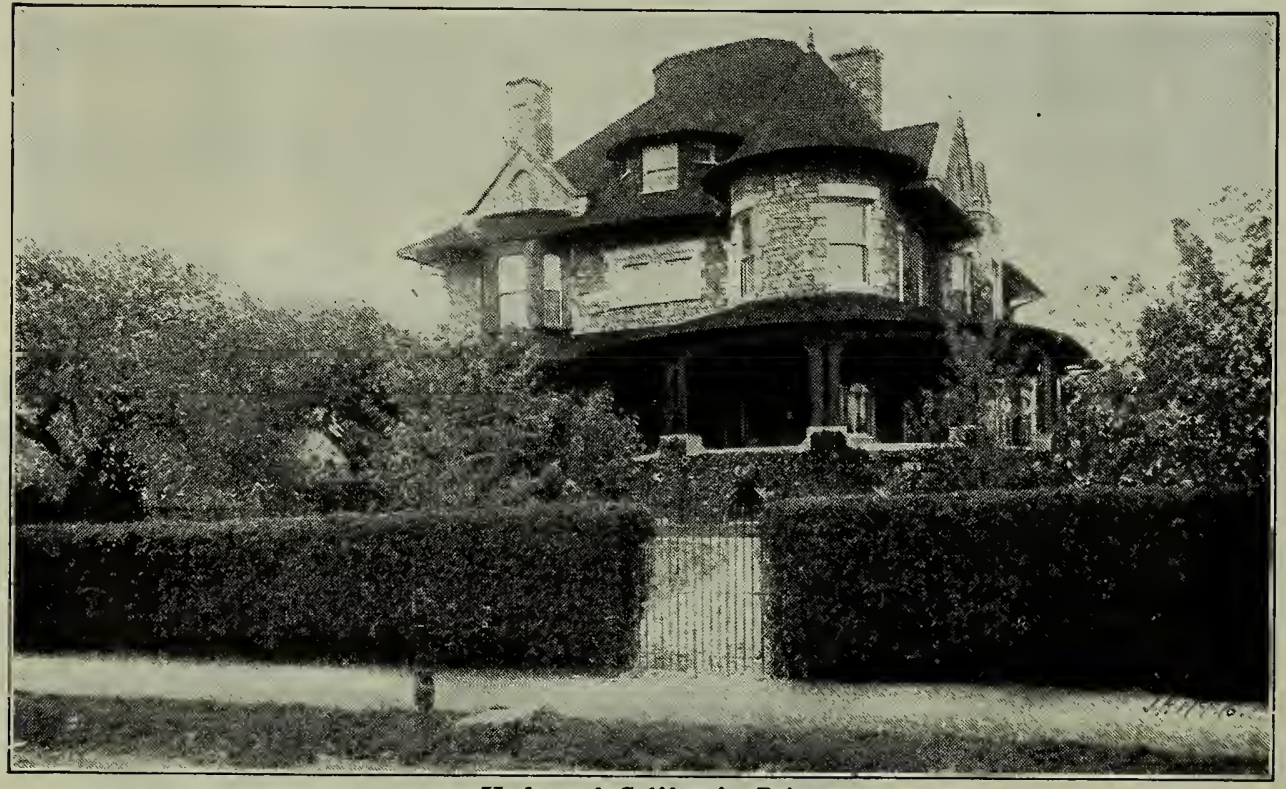

Hedge of California Privet

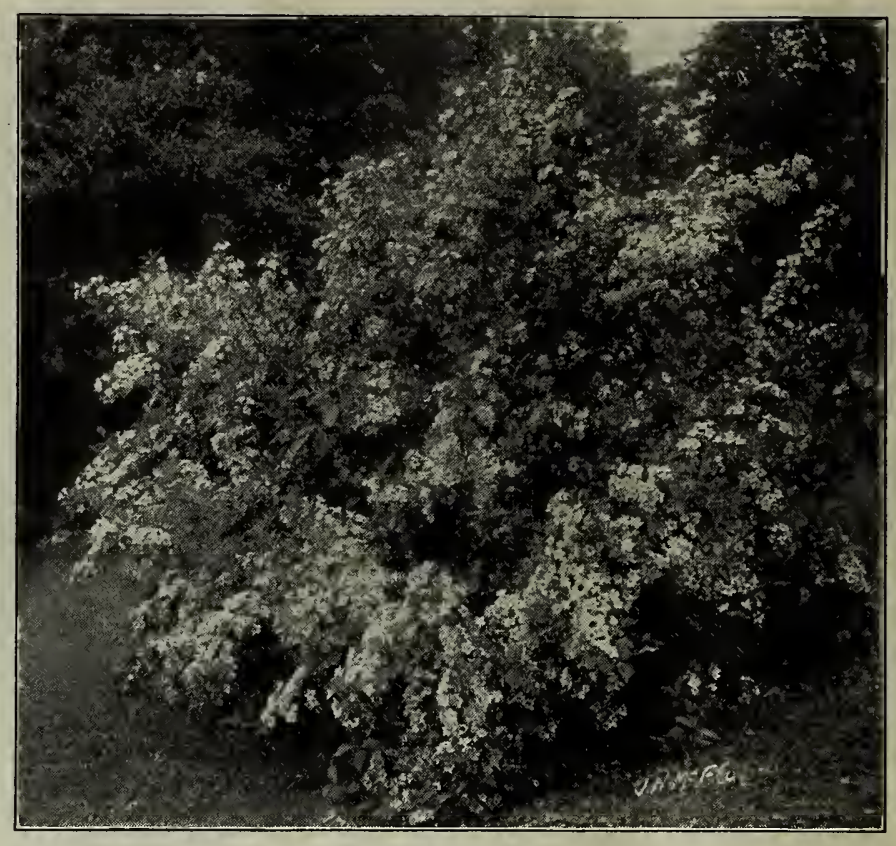

Weigela rosea

CALIFORNIA PRIVET. Where a stiff, upright hedge is wanted, nothing is more desirable than California Privet. It is a quick, strong-growing plant, yet easy to control by use of knife or shears to any desired shape. It is alike fine for hedging between city lots, on large rural grounds, parks and cemeteries or, if allowed to grow without trimming, it is excellent for screens, for fences and outbuildings. Very easy to grow on any soil, doing well even in partial shade. Almost evergreen, its rich leathery leaves turning to a purplish hue late in winter.

Barberry, Common and Purple-

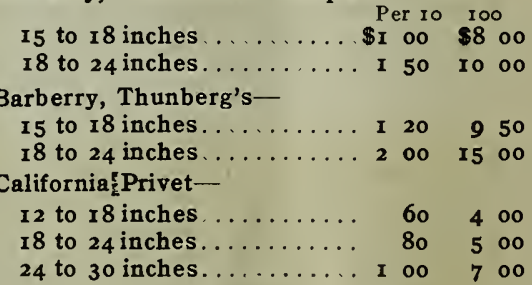

\section{ASSORTED SHRUBS}

We know of nothing that will create a more pleasing effect than a studied assortment of the high-growing shrubs. Planted with regard to foliage contrasts and different blooming seasons, such a hedge puts forth new beauties each month, and will be the delight of the planter. We particularly recommend for this purpose Althæas of various colors, the Purple-leaved Filbert, the Hydrangeas, any of the Bush Honeysuckles, the Philadelphus, the Spiræas, especially the Bridal Wreath and Van Houttei, the Lilacs, Viburnums and Weigelas. See Deciduous Ornamental Shrubbery.

GROW YOUR OWN HEDGE FROM ONE-YEAR, WELL-ROOTED, 6- TO 8-INCH PLANTS

Barberry, Purple-leaved, at a special price of $\$ 3$ per roo. Barberry, Thunberg's, at $\$ 3.75$ per 100.

Althæa, 8 inches, at $\$ 2$ per 100 .

The above are well worth your consideration

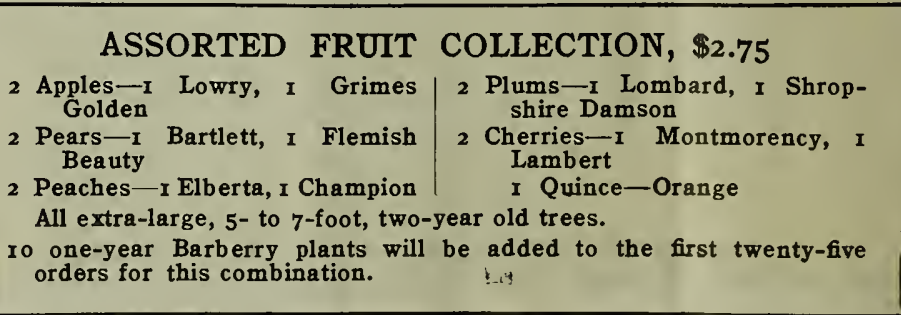




\section{HARDY PERENNIAL PLANTS}

Of late years there has been quite are revival of interest in the old-fashioned hardy garden perennials, and little wonder, because there is not a time during the whole flower season in which from one to a half-dozen are not in bloom. By making a judicious selection, one may have a continuous display of bright and showy flowers from May to November.

ANEMONE (Windflower). There are a number of forms and colors of the Anemone, all of which are particularly fine. We list the following, being the best of the class:

Queen Charlotte. A beautiful new variety, with large, semidouble flowers of exquisite pink.

Rubra. Deep red, with yellow center. Blooms from September until frost.

Whirlwind. Semi-double, pure white.

I5 cts. each, $\$ 1.25$ for 10

AQUILEGIA (Columbine). The Columbines have an established place in all perennial gardens. Their curious forms and many pleasing shades of color, and the readiness with which they adapt themselves to all localities, have made them prime favorites.

Cærulea. Blue and white.

Canadensis. Bright red and yellow.

Chrysantha. A yellow species; one of the best. $15 \mathrm{cts}$, each, $\$ 1.20$ for ro

COREOPSIS grandiflora. A beautiful, hardy border plant, producing large yellow flowers on long stems; fine for cutting; early summer until late frost. I $5 \mathrm{cts}$. each, $\$$ I.20 for IO.

DELPHINIUM, Belladonna (Larkspur). A remarkably tallgrowing, showy plant, with beautifully cut leaves and turquoiseblue flowers from the last of June until frost. $25 \mathrm{cts}$. each, \$2 for Io.

DIGITALIS purpurea (Foxglove). Prefers a little shade or a cool, somewhat moist location. Produces thimble-like flowers in immense spikes during July and August. I 5 cts. each, \$I.20 for Io.

FUNKIA Japonica (Day Lily). Pale green, broad foliage and large fragrant, pure white, wax-like flowers. Blooming, as it does, in September, it is a great favorite. $20 \mathrm{cts}$. each, \$I for 6.

GAILLARDIA grandiflora (Blanket Flower). Makes one of the most gorgeous and prodigious displays of all perennials. Flowers measure 3 inches in diameter, on 2 -foot stems. A hard center of deep maroon is thickly bordered by petals of orange and yellow, strikingly ringed by circles of crimson, red and maroon. With these in the garden a constant show is assured from June until frost. I 5 cts. each, \$1.20 for Io.

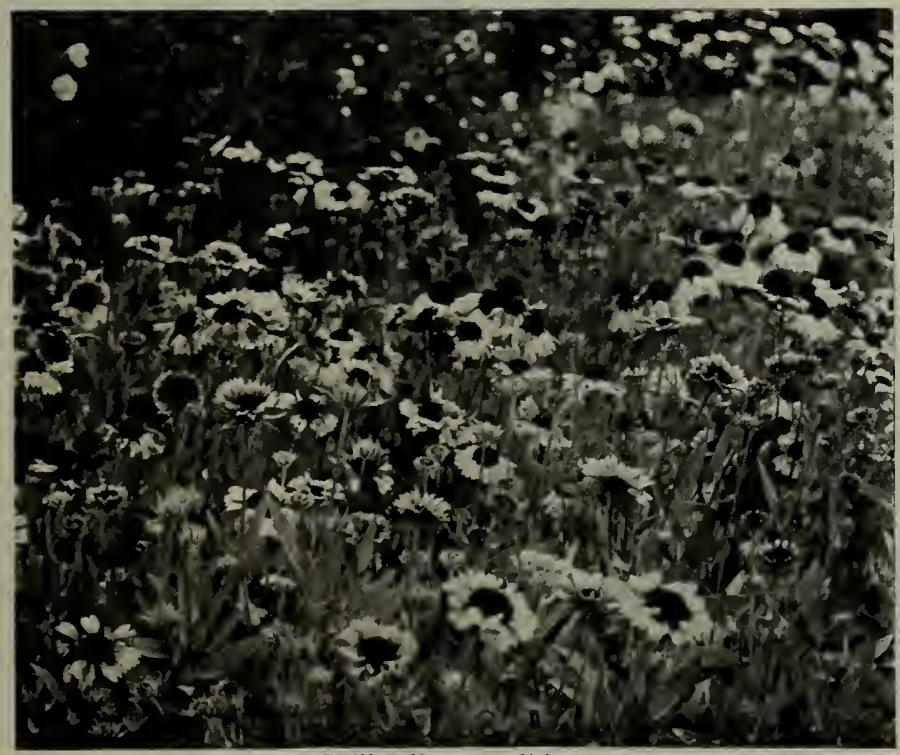

Gaillardia grandiflora

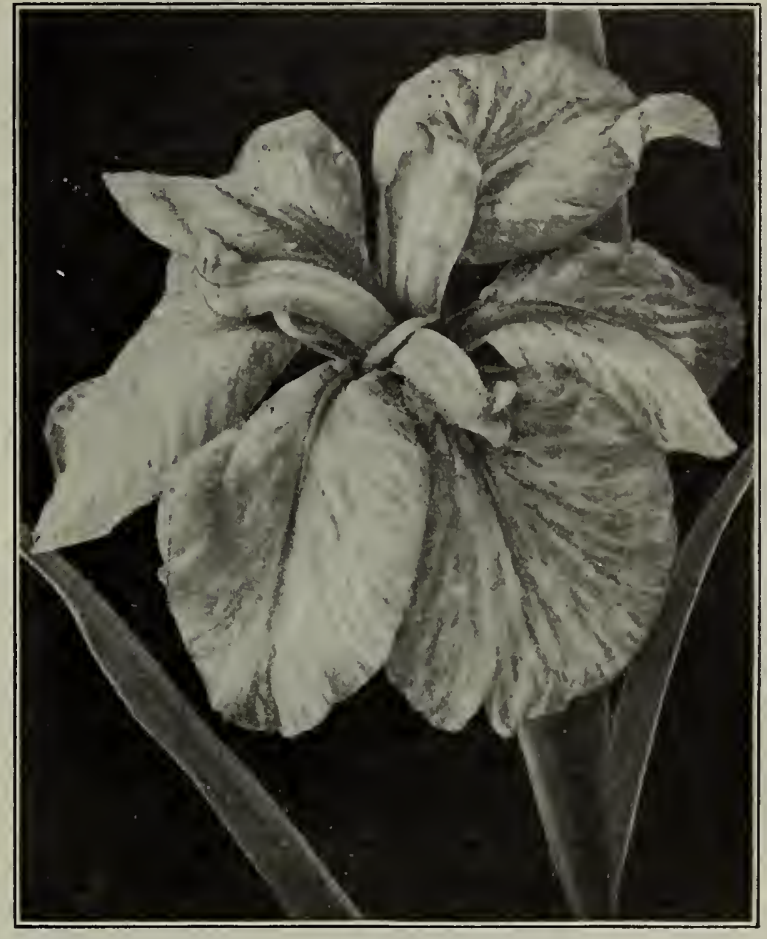

Japanese Iris

HIBISCUS Moscheutos (Mallow). Large, purplish pink flowers. Grows 4 to 5 feet high, and blooms in August and September. Very attractive. Io cts. each, $90 \mathrm{cts}$. for Io.

Crimson Eye. Large white flowers, with crimson centers. Io cts. each, 90 cts. for 10.

Meehan's Mallow Marvels. A perfected strain la tely introduced. Flowers 8 to ro inches in diameter, and ranging in color through the various shades of red, pink and white. $35 \mathrm{c}$. each, $\$ 3$ for 10.

IRIS, German. Among the most showy and beautiful of early flowering perennials. They bloom in the greatest profusion in spring and early summer, and are fine for cut-flowers. Their purity of beauty and haunting fragrance are decidedly refreshing. ro cts. each, $90 \mathrm{cts}$. for $r 0$.

Japanese. Flowers differ from the German Iris in being broad and flat. They exhibit a wonderful variety of color and shades. A well-established plant gives a dozen or more flower-stalks, 2 to 3 feet high, each stalk producing two to four enormous blooms. I 5 cts. each, $\$ 1.20$ for 10 .

PEONIES. Among all the splendid plants grown in the hardy garden, there is none which can, in any way, equal the Peony, if one's tastes run to large, impressive blooms. In late spring and early summer the Peony produces beautiful flowers, rivaling the rose in brilliancy of color and perfection. The plants are very hardy, needing no further protection than they afford themselves. Attractive in the extreme whether planted singly or in masses. We are offering the following colors strong, two-year roots, that if planted in good, rich soil should produce bloom the first year. Light Pink, Dark Pink, Red an White. 25 cts. each, \$2 for Io.

PLAT YCODON grandiflora (Bellflower). A beautiful perennial forming a dense, branching bush of upright habit; foliage very neat; bears a constant succession of handsome, large, bell shaped, deep blue flowers from July until frost. I $5 \mathrm{cts}$. each, $\$ 1.20$ for 10 . 


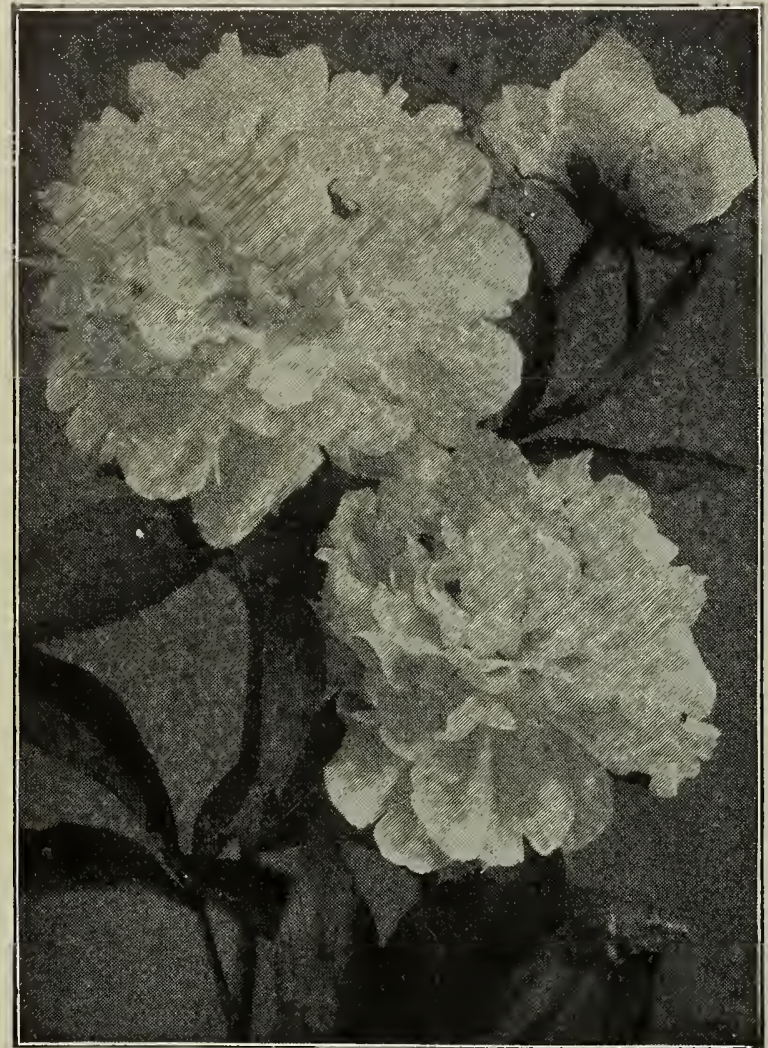

White Peonies (see page 25)

\section{HARDY PERENNIAL PLANTS, continued}

PHLOX, Hardy. It is no exaggeration to say that the Hardy Phlox is among the best and most popular garden flowers. For producing an elaborate show of color it has no equal. It produces a fine effect when grouped with other plants in the hardy border, furnishing brightness after the shrubs are done blooming; in fact, they do much to make the garden gay throughout the entire summer. The Phlox thrives in any ordinarily rich soil, and is not subject to insect pests. It glories in plenty of sunshine and water.

Bacchante. Tall-growing; Tyrian rose, with crimson eye.

Beranger. Dwarf, large-flowering; pink and white, purple eye.

Coquelicot. Glowing orange-red, with violet eye.

Miss Lingard. The earliest white, lavender eye. A profuse bloomer.

Pantheon. Extra-large, flat flowers of salmon-rose.

Bridesmaid. White, with sharply defined carmine-rose eye.

R. P. Struthers. Brilliant rosy red, with crimson eye. 15 cts. each, $\$ 1.20$ for 10

RUDBECKIA (Golden Glow). The double, yellow, dahlia-like flowers borne on stems 6 to 8 feet high, in great profusion, make it a very conspicuous plant during August. The most admired yellow-flowering perennial. Is cts. each, \$r.20 for ro.

TRITOMA Pfitzeri (Red-Hot-Poker Plant). One of the most striking flowers in cultivation. Has sword-like leaves, 2 to 3 feet long, and a 3- to 4 -foot flower-stalk, which is crowned by a 5 - to 6 -inch spike, made up of numerous drooping florets an inch long and of flaming orange-reddish hue. Blooms from late July until frost. Cannot be excelled as a border plant. 35 cts. each, $\$$ r for 4 .

\section{VINES AND GLIMBERS}

AMPELOPSIS quinquefolia (Virginia Creeper). A native vine of rapid growth, with large, luxuriant foliage which, with the coming of autumn, assumes the most gorgeous crimson and purple hues. 2 yrs. $20 \mathrm{cts}$. each.

Veitchii (Boston Ivy). The most popular and best of all climbers for covering walls, stumps, rocks, etc. It clings firmly to brick, stone or other material, and forms a perfect coat of deep, glossy green foliage, which turns to crimson and gold in autumn. The leaves are ivy-shaped and lap closely over each other, presenting a dense mass of delightful verdure. It spreads rapidly and although of frail habit it is hardy as the oak. 2 yrs. 25 cts. each.

CLEMATIS paniculata. A fast-growing, clean vine, which quickly shades porches or covers pillars and trellises. In August and September, when most other shrubs and vines have ceased blooming, its luxuriant, glossy foliage is almost completely hidden by a sheet of billowy whiteness made up of numerous white, star-like flowers, and so fragrant as to sweetly perfume the air for a great distance. If only one vine can be planted no other should be considered. 2 yrs. 25 cts. each.

Clematis, Large-flowering Sorts:

Henryi. Creamy white.

Jackmani. Velvety violet-purple.

Madame Edouard Andre. Crimson-red.

$$
\text { Each variety, } 2 \text { yrs., } 50 \text { cts. each }
$$

LONICERA Halliana (Hall's Japan Honeysuckle). The one really popular Honeysuckle. Its vining qualities are all that can be desired, but it makes its strongest bid for favor through its delightful, fragrant flowers which appear through the summer in rich profusion. Flowers white, later turning to yellow. Holds its leaves late into the winter. 2 yrs. $25 \mathrm{cts}$. each.

MATRIMONY VINE. A neat, half-climbing plant, bearing small, light pink flowers in summer, followed by berries, which turn to beautiful scarlet in the fall. 2 yrs. 25 cts.

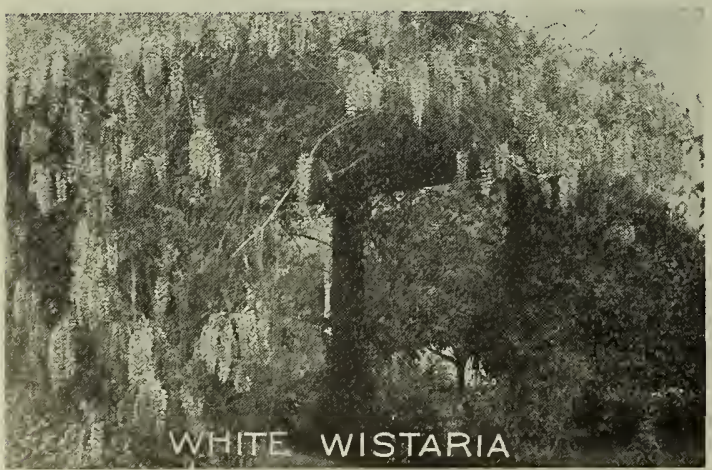

WISTARIA magnifica. Flowers in dense, drooping racemes of pale lavendercolor. An excellent vine of good habit. 2 yrs. 35 cts.

Sinensis alba. A very striking vine for porch decoration or trellis-work. Its white flowers are produced in long, pendulous clusters; very hardy. 2 yrs. 50 cts. each.

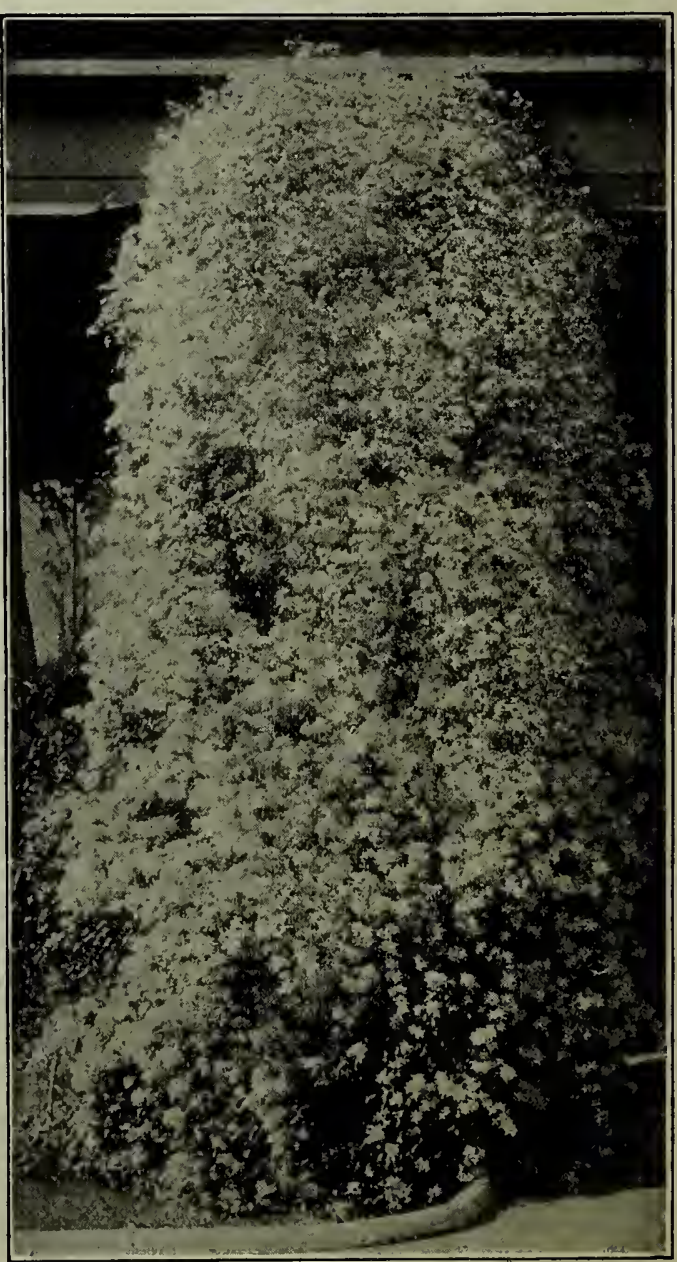

Clematis paniculata 


\section{EVERGREENS IN POTS}

The evergreen family, in its many varieties, is distinctly beautiful. They are moderately slow growers, consequently they sell at good, round prices. To meet what has been a long-felt need, we have prepared ourselves to place some of the very finest species in every home at a nominal sum. For the first time we are offering them in one-year pot-grown plants. This is a chance for you to secure some of the finest varieties grown at very low prices, and besides you will have all the fun in watching the little fellows unfold new beauties from year to year as they develop into larger specimens.

During the first two years the many delicate green shades of their foliage will add much to your window flower collection. The gold-tipped varieties will produce effects that cannot be equaled by any hothouse plant. As they grow larger, they can be transplanted to larger pots and, finally, when they become too big for house or porch plants, they can be planted on your lawn, where they will continue to put forth new beauties for succeeding generations. Io cts. each, \$I per doz., \$7 per Ioo.

ARBORVIT $Æ$. The Arborvitæs have bright green, airy foliage, the variety Hovey's being gold-tipped.

$\begin{array}{lll}\text { American } & \text { Siberian } & \text { Pyramidalis } \\ \text { Hovey's Golden } & \text { Globosa } & \end{array}$

JUNIPER. The Junipers are very handsome, neat and clean. They do well in all soils, and are especially effective in small yards for grouping. The varieties named golden have gold-tipped foliage.

$\begin{array}{ll}\text { Common Golden } & \text { Virginian Blue } \\ \text { Tamarisk-leaved } & \text { Japan Golden }\end{array}$

Slender Golden

Tamarisk-leaved Japan Golden

RETINOSPORA. The Retinosporas are really the finest of all evergreens. Their soft, plume-like foliage receives much admiration wherever seen.

$\begin{array}{lll}\text { Argentea } & \text { Tom Thumb } & \text { Squarrosa } \\ \text { Ericoides } & \text { Plumosa } & \text { Sulphurea } \\ \text { Plumosa aurea } & \text { Pisifera } & \end{array}$

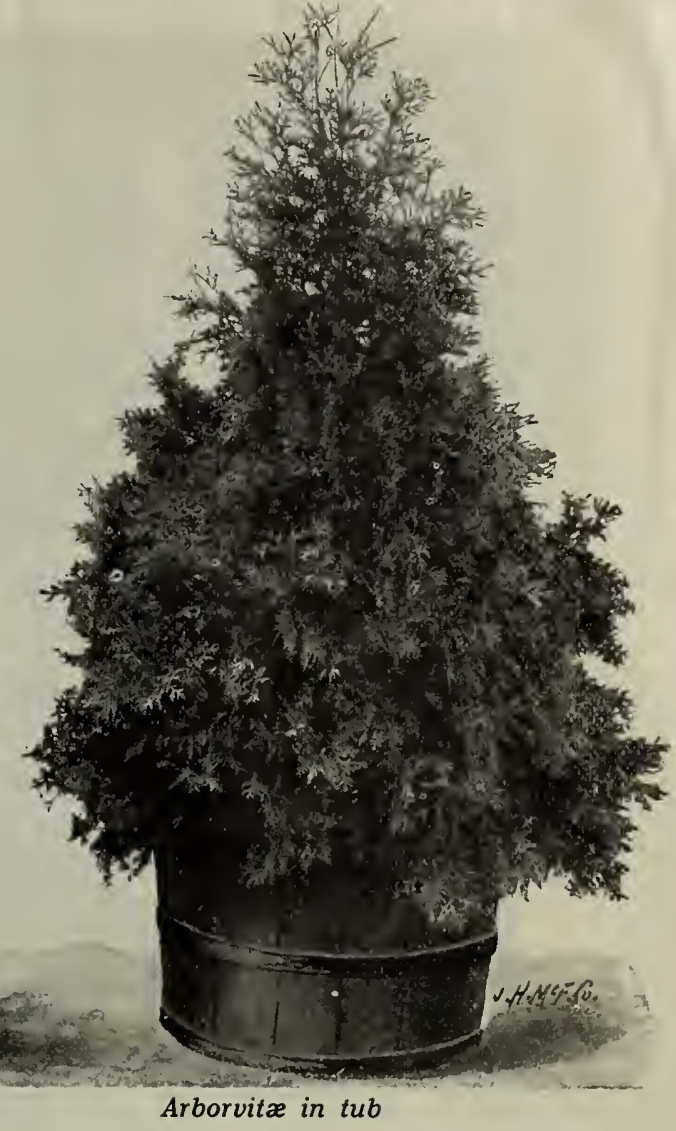

Let us help you make a selection of a dozen of these vigorous little plants, and we guarantee that, if you are a flower-lover, these will stand first in your affections long before the first season is over.

If you are interested in large specimens, we have a good assortment of the different species anywhere from I 8 inches to 7 feet high, and shall be glad to quote you prices.

\section{HARDY GARDEN ROSES}

While our list of Roses is not large, it is made up of those most highly prized by flower-lovers.

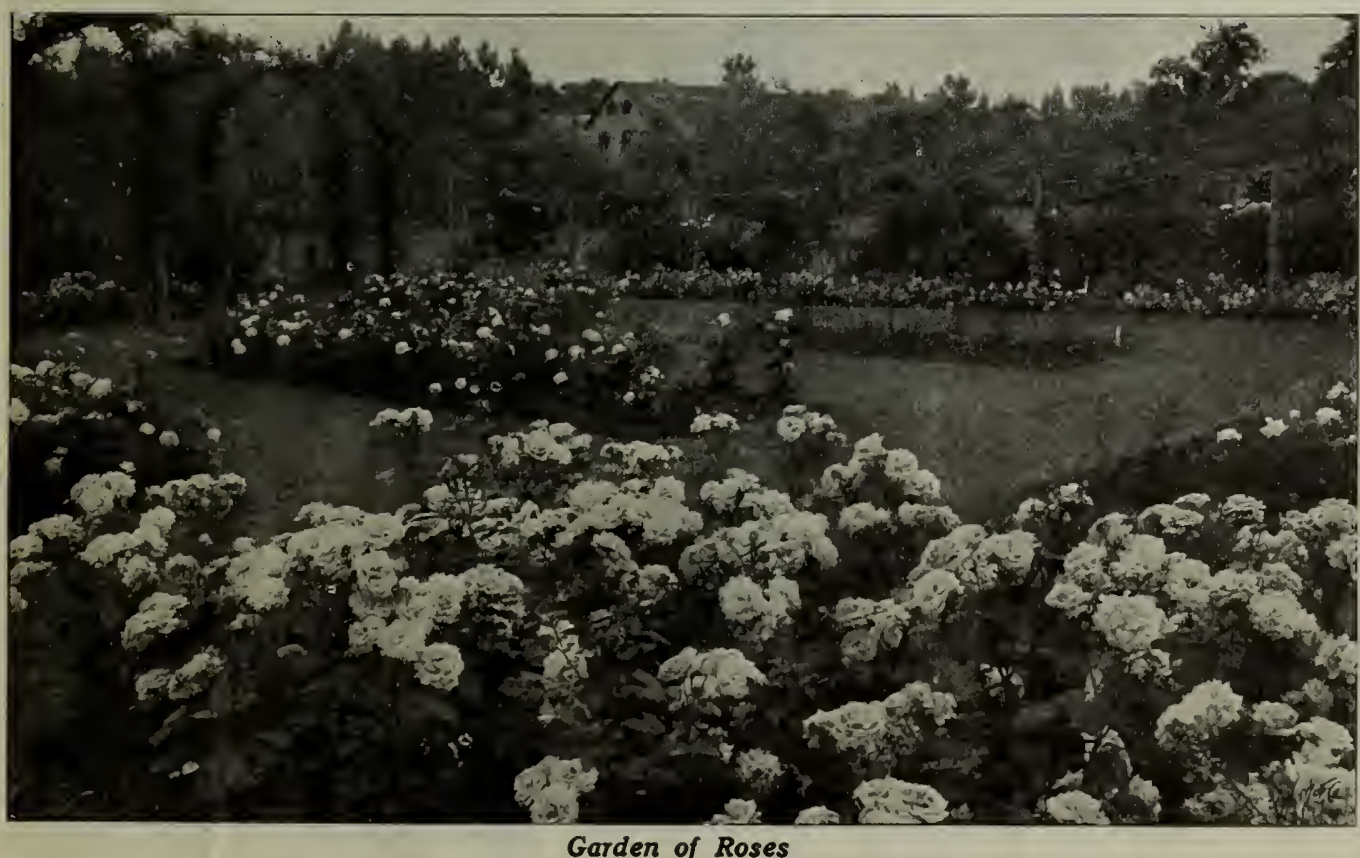

Make your selection from the following, and assure yourself that you are getting only the truly beautiful varieties.

Hybrid Perpetual or Monthly Roses bloom profusely in June and at intervals throughout the summer. They are extremely hardy.

Tea Roses are almost constant bloomers; the shapely buds breaking out in their many delightful tints in early summer and continuing throughout the entire season. They require some little protection in winter.

Climbing and $\mathrm{R}$ a mbler Roses are great favorites for porch, wall or trellis decorations. They are more than generous in their bloom, and each year put forth a wealth of foliage and new growth.

Prices, unless otherwise noted, $35 \mathrm{cts}$. each, $\$ 3$ for 10 


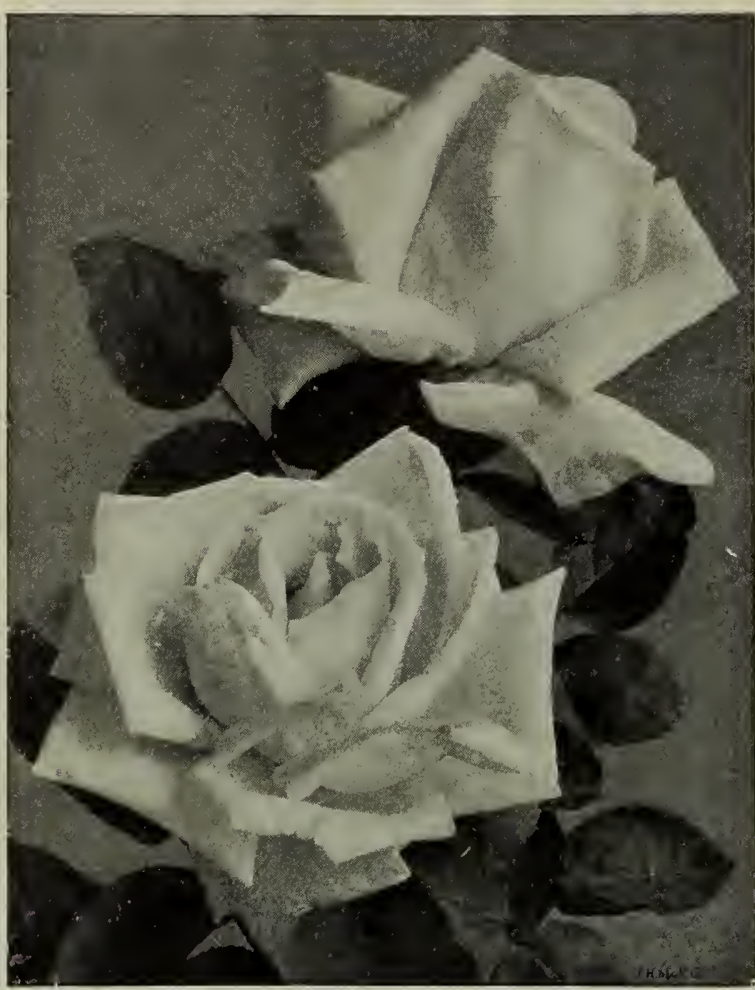

Frau Karl Druschki Roses

\section{HYBRID PERPETUAL Or MONTHLY ROSES}

Alfred Colomb. A superb, brilliant crimson Rose, of very large, full form; extremely fragrant; blooms freely and grows well.

Clio. The color is a delicate satiny blush, with slightly deeper center. The plant is strong and blooms freely, displaying its great flowers boldly on good stems, against large, rich leaves. A Rose of perfect form and finish, with broad, thick petals, high, full center; beautiful from pointed bud to open flower.

Frau Karl Druschki. The finest white hybrid Rose, with large, full flowers of splendid form. It is marvelous in its beauty in half-open bud and in the clear white of the full-open bloom. Flowers from June until autumn. $40 \mathrm{cts}$. each.

General Jacqueminot. Brilliant crimson; very large and extremely effective. A general favorite wherever planted.

Margaret Dickson. Of magnificent form; white, with pale flesh center; petals very large, shell-shaped and of great substance; fragrant. A fine variety; foliage very large, dark green.

Mrs. John Laing. Soft pink; large and of fine form, produced on strong stems; exceedingly fragrant; one of the most valuable varieties for forcing, and flowers continuously in open ground.

Paul Neyron. Flowers of immense size and beauty; one of the largest Roses grown and one of the finest; color deep crimson, very fresh and pretty. A strong grower and an all-summer bloomer.

\section{TEA ROSES}

Caroline Testout. Large and double; color clear, bright rose. Of very sturdy habit and an abundant bloomer. This is the Rose which has become a feature of the West, and has given to Portland, Oregon, the name of "Rose City."

Kaiserin Augusta Victoria. White, blended with cream-color; very large, full and double, almost perfect in form, and it continues beautiful even when fully expanded; a most generous bloomer.

Killarney. The exquisite shade of pink of this most beautiful Rose is hardly equaled by any other variety. Very fragrant; the buds are exceedingly large and of beautiful form; the flowers of immense size; the bush is of magnificent growth and bears its beautiful burden of flowers all summer.

\section{TEA ROSES, continued}

La France. Very large, double and of superb form; color delicate silvery rose. A most constant bloomer. One of the sweetest and most useful of Roses.

Maman Cochet. Flowers large, full, clear carmine-rose, shaded with salmon. Plant very vigorous and free-flowering.

\section{HARDY GLIMBING AND RAMBLER ROSES}

Baltimore Belle. Delicate pink flowers in large clusters, giving the whole plant the appearance of a perfect mass of bloom. A very hardy climber.

Crimson Rambler. Very vigorous, making a growth of from 8 to ro feet in a season. The panicles of Roses are large and remain perfect for several weeks. This is the famous crimsonclustered climber, so effective when grown on pillars, porches and trellises. Extremely hardy.

Dorothy Perkins. Flowers a beautiful shell-pink; foliage finer, smoother and darker than Crimson Rambler.

Flower of Fairfield. The new, everblooming Crimson Rambler. There never was a Rose more liberally planted than the old Crimson Rambler, and in June the whole country is ablaze with its gorgeous crimson flowers. The one fault of the Crimson Rambler is that it does not last long enough. This fault has been eliminated in this new everbloomer, which puts forth its flowers in rich profusion throughout the entire summer. The flowers are very compact, and much more brilliant than the old Crimson Rambler. 50 cts. each.

Tausendschon (Thousand Beauties). The sensational new climber, producing on the bush so many different colors and tints that it is impossible to describe the variation, hence the name, "Thousand Beauties." The colors run from delicate rose through the intermediate shades of bright rose and carmine, with white and yellow tints showing. A strong grower, with few thorns and absolutely hardy. $50 \mathrm{cts}$. each.

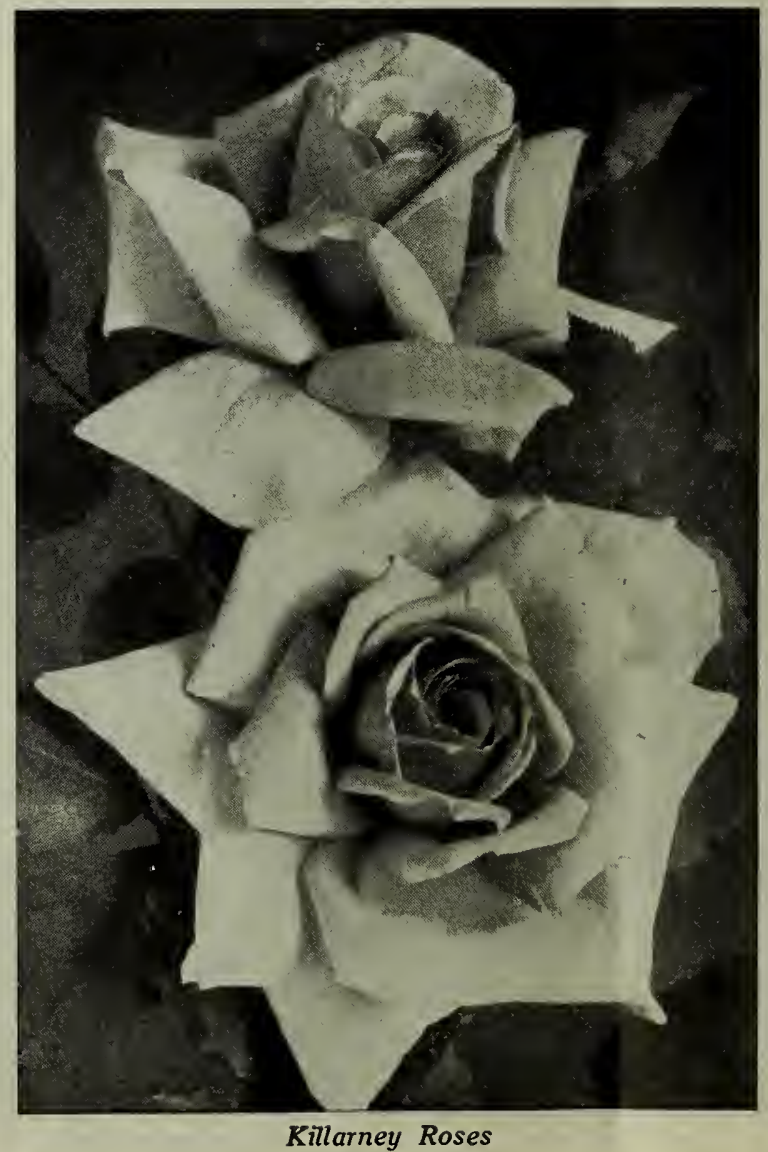


HARDY CLIMBING AND RAMBLER ROSES, continued

Veilchenblau (Blue Rambler). This new rambler is hailed by European growers as the forerunner of a true Blue Rose. The color on first opening is purplish pink. then turns to amethyst, and finely shades to steel-blue. The yellow stamens appear in sharp contrast to the blue petals. Certainly a valuable addition to any Rose collection. $75 \mathrm{cts}$. each.

Yellow Rambler. Light canary shade; clusters small, individual flowers of good size.

\section{MISCELLANEOUS HARDY ROSES}

Crimson Baby Rambler. This wonderful addition to the Rose family is free from insects and absolutely hardy everywhere. Color clear, brilliant ruby-red; foliage dark and glossy. It grows only to a height of about 20 inches, and blooms constantly throughout the summer. For creating solid beds of low-growing Roses of brilliant color, no Rose is the equal of the Baby Rambler on account of its unique character, and for growing as a pot-plant it has no superior. It is also a choice plant for edging borders of shrubs, other Roses or perennials. $50 \mathrm{cts}$. each.

Wichuraiana. The handsome trailing Japanese Rose so useful in covering rockeries, mounds or embankments. The pure white, single flowers appear in great profusion in July, while its almost evergreen foliage makes it very desirable at all seasons of the year. $40 \mathrm{cts}$. each.

Soleil d'Or. A fine, hardy, outdoor Rose, of much the same character as the Hybrid Perpetuals. Color gold and orange-yellow, varying to ruddy gold, suffused with nasturtium-red. $45 \mathrm{cts}$. each.

Tree Roses. Grafted on 4- to 5-foot hardy Rose stocks, making a very handsome addition to the lawn or Rose-garden. We can supply them in white and in the different shades of pink and crimson. Si each.

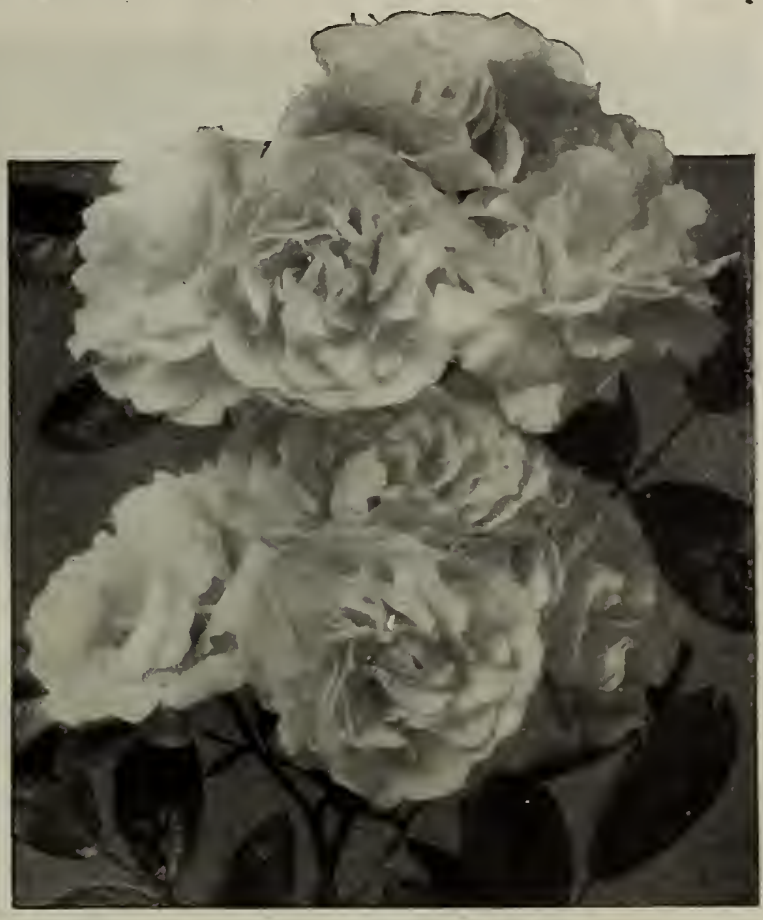

Tausendschon Roses

\section{Summer- and Autumn-Flowering Bulbs MUST BE TAKEN UP IN THE FALL AND KEPT FROM FREEZING}

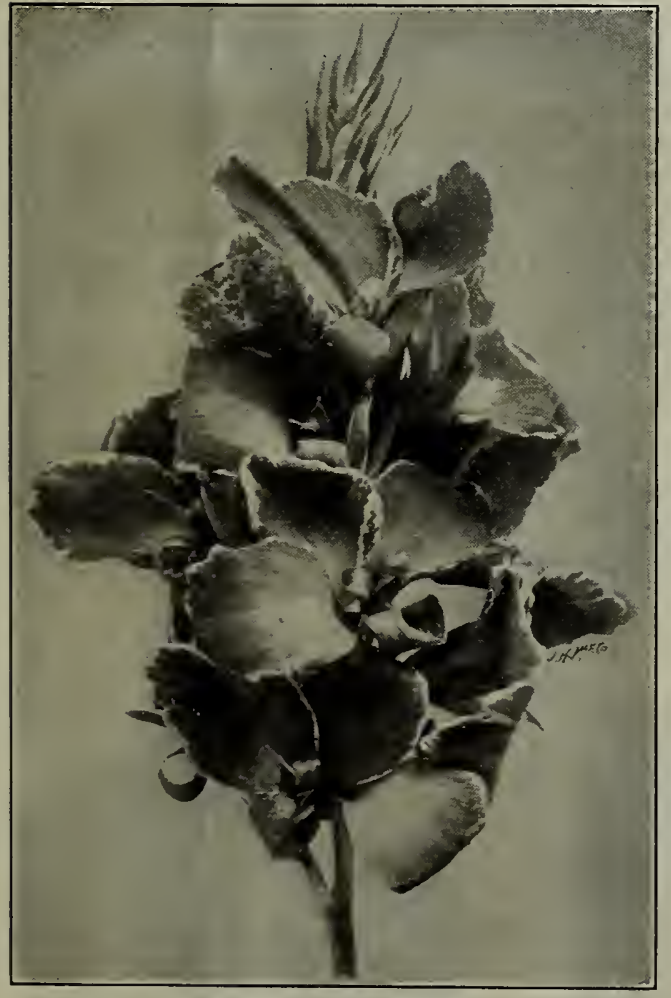

Flower Truss of Canna

SWEET CHERRY BARGAIN, $\$ 1.25$

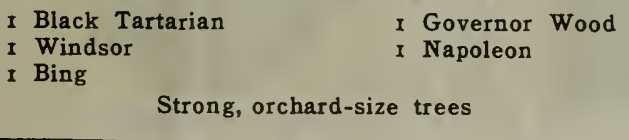

\section{CANNAS}

A bed of well-grown Cannas is a veritable bit of the tropics, with their wide. arching leaves and stiff stalks of flaming flowers. This effectiveness is not confined to only a few weeks' display, but being exuberant in growth, a bed of Cannas soon becomes attractive after planting. and each day thereafter adds to its beauty.

Flamingo. Tall-growing; bright orange-scarlet flowers well displayed above the foliage. 4 feet. Io cts. each, \$I per doz.

Florence Vaughan. Conceded by all to be the best yellow-spotted Canna. Flowers very large, of perfect form, with broad, overlapping petals, nicked at ends. Color brilliant yellow, spotted with red. 3 feet. ro cts. each, Si per doz.

Richard Wallace. Tall-growing, heavy trussed, canary-yellow, the largest and best of its color. 4 feet. I 5 cts. each.

Louisiana. A strong, vigorous grower, producing a dense mass of glossy green foliage and vivid scarlet flowers, often measuring 7 inches across. 6 feet. 20 cts. each. S2 per doz.

Wyoming. A beautiful new variety of purplish bronze foliage. Flowers large, bright orange, slightly rimmed with rose. 6 feet. $25 \mathrm{cts}$. each, \$2.50 per doz.

\section{DAHLIAS}

Well-known autumn-flowering plants, growing from 2 to 5 feet high, and producing a profusion of flowers of the most perfect and beautiful forms. Colors: Pink , Red. Yellow and White. I 5 cts. each. Si.35 per doz.

\section{GLADIOLI}

These good old-fashioned flowers have come back as prime favorites with every body. They grow in any good garden soil with very little care, even doing well in dry seasons. The handsome shadings of their blossoms have no equal. Choice mixerl bulbs, 35 cts. for $6, \$_{4}$ per roo.

\section{TUBEROSES}

Fall-flowering bulbs whose popularity has never waned. Aside from the beauty of their long. compact spikes of double flowers, their exquisite perfume affords one of the most positive delights of the fall garden. 5 cts. each, 35 cts. per doz., $\$ 2.25$ per 100. 


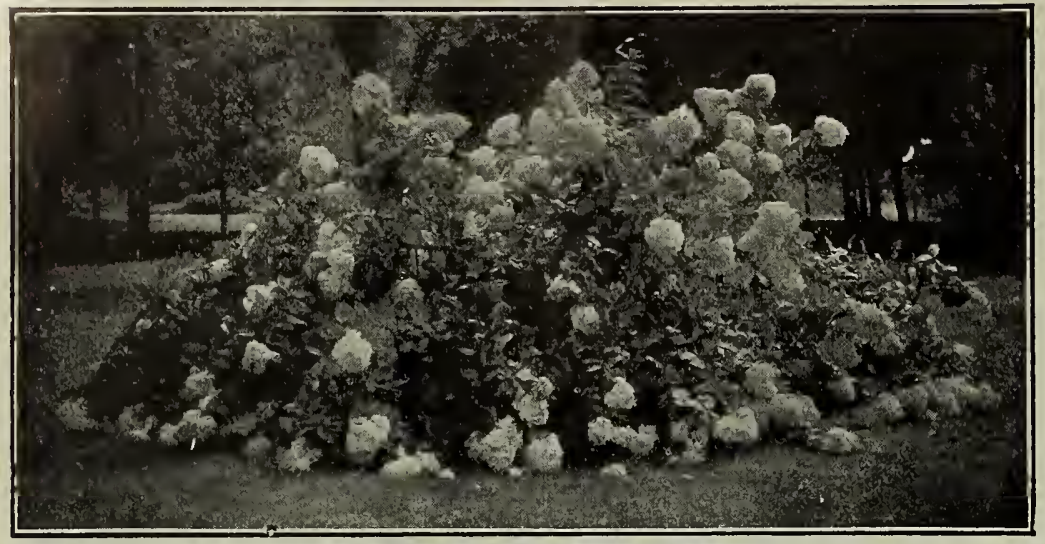

Hydrangea paniculata grandiflora

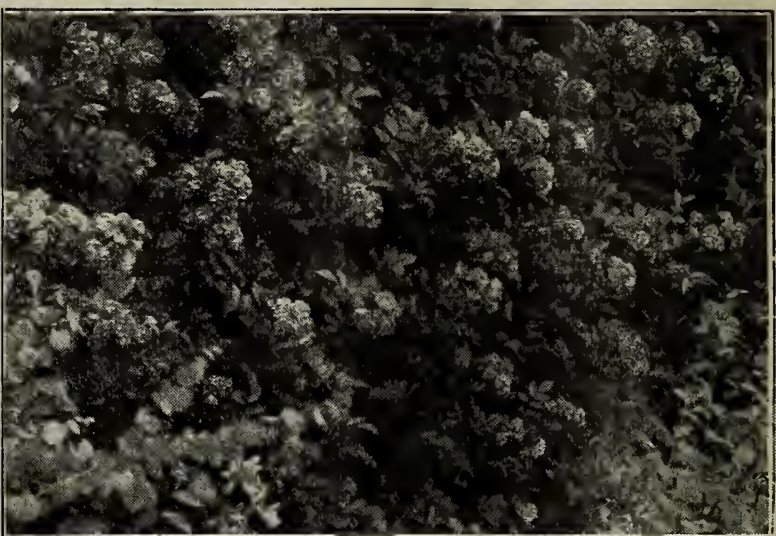

Crimson Rambler Roses

\section{Parcel Post Bargain Combination Page}

Progress pays the Postage. Uncle Sam delivers right at your door. Pick them out.

All stock will be Progress high-quality, one-year mailing size. In ordering, designate number of the combination wanted.

\section{5-cent Combinations \\ No. 1 \\ No. 6}

1 Retinospora plumosa aurea

1 Arborvitæ, Tom Thumb

1 Juniper, Irish

Little, shapely specimens, whose like foliage will add much to your flower collection.

No. 2

1 Pink Peony

1 Red Phlox

$$
\text { No. } 3
$$

Two vines, each worth more than the combination price

1 Clematis paniculata

1 Ampelopsis Veitchii

\section{No. 4}

Three Favorite Shrubs

1 Spiræa, Anthony Waterer

1 Symphoricarpos racemosus

1 Philadelphus aurea

$$
\text { No. } 5
$$

Two fine fruits

1 Lowry Apple

1 Crosby Peach
A full bed of Strawberries

5 Senator Dunlap

5 Haverland

5 Bubach

No. 7

3 Tuberoses

3 Gladioli

1 Canna

No. 8

1 Dahlia

No. 9

2 Barberry, Vulgaris

2 Barberry, Purple

1 Barberry, Thunbergii

No. 10

1 Cassia Marylandica

1 Honeysuckle, Morrowi

1 Symphoricarpos vulgaris

No. 11

1 Spiræa opulifolia

1 Hydrangea

1 Arborvitæ pyramidalis

\section{0-cent Combinations \\ No. 12 \\ No. 16}

Three Best Raspberries

5 Cuthbert

5 Kansas

2 St. Regis

No. 13

1 Pink Phlox

1 White Phlox

1 Dark Red Phlox

1 Carmine Phlox

No. 14

5 Tuberoses

5 Gladioli

No. 15

30 Strawberries

5 Gandy

5 Haverland

5 Senator Dunlap

5 Warfield

5 Bubach

$5 \mathrm{Wm}$. Belt

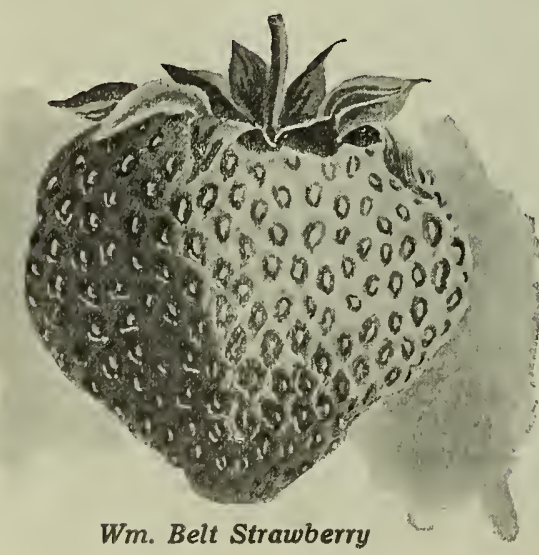

Wm. Belt Strawberry

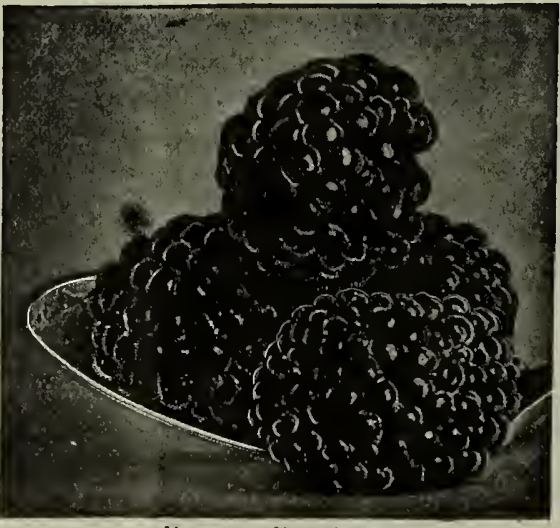

Kansas Kaspbernes

30
15 Purple Barberries

No. 17

1 Gaillardia

1 Hibiscus

I Platycodon

1 Delphinium

1 Hydrangea

No. 18

1 Crimson Rambler

1 Calycanthus

1 Althæa

No. 19

20 Strawberries and 10 Raspberries our selection

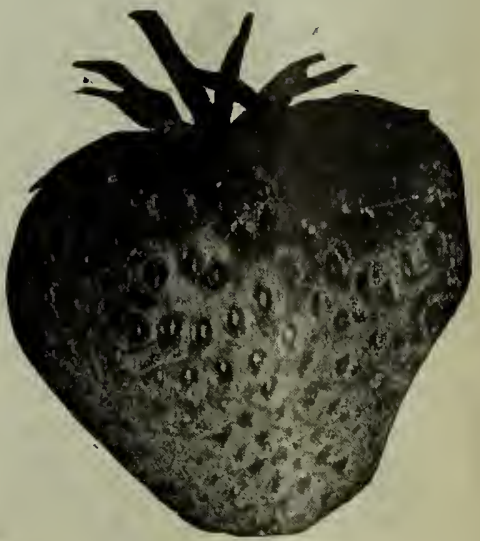

Bubach Strawberry 


\section{SPRAYING}

The necessity of spraying is acknowledged by all authorities as being one of the requirements of successful fruit-growing. An enormous amount of money has been spent during the last few years in every state in the Union for the study of sprays and mixtures. and the value of each. Spraying not only insures better fruit, but more of it, greatly increasing its quality and value.

\section{TABLE FOR SPRAYING}

\begin{tabular}{|c|c|c|c|c|}
\hline & 1st Application & 2d Application & 3d Application & 4th Application \\
\hline Apple & $\begin{array}{l}\text { Before buds start, copper } \\
\text { sulphate solution and ar- } \\
\text { senate. }\end{array}$ & $\begin{array}{l}\text { After the blossoms have } \\
\text { formed but before they } \\
\text { open. }\end{array}$ & $\begin{array}{l}\text { Within a week after the } \\
\text { blossoms fall, bordeaux } \\
\text { mixture and arsenate. }\end{array}$ & $\begin{array}{l}2 \text { weeks later, bordeaux mix- } \\
\text { ture and arsenate. }\end{array}$ \\
\hline Cherry & Before buds open, bordeaux. & $\begin{array}{l}\text { When the fruit has set, bor- } \\
\text { deaux. }\end{array}$ & $\begin{array}{l}2 \text { week later, bordeaux or } \\
\text { kerosene. }\end{array}$ & $\begin{array}{l}2 \text { weeks later if necessary, } \\
\text { bordeaux and arsenate. }\end{array}$ \\
\hline Pear & Before buds open, bordeaux. & $\begin{array}{l}\text { When the blossoms have } \\
\text { formed but before they } \\
\text { open, bordeaux or kerosene. }\end{array}$ & $\begin{array}{l}\text { Within a week after the } \\
\text { blossoms fall, bordeaux or } \\
\text { kerosene. }\end{array}$ & $\begin{array}{l}\text { Repeat in } 2 \text { weeks if neces- } \\
\text { sary, bordeaux mixture or } \\
\text { kerosene. }\end{array}$ \\
\hline Plum & $\begin{array}{l}\text { Before buds open, bordeaux. } \\
\text { Black Knots should be cut off }\end{array}$ & $\begin{array}{l}\text { As soon as the blossoms fall, } \\
\text { bordeaux. } \\
\text { and burned whenever found. }\end{array}$ & $\begin{array}{l}2 \text { weeks later, bordeaux or } \\
\text { paris green. }\end{array}$ & $\begin{array}{l}\text { Repeat at intervals of } \\
\text { weeks if necessary. }\end{array}$ \\
\hline Peach & $\begin{array}{l}\text { Very early, before April I, } \\
\text { copper sulphate }\end{array}$ & 2 weeks later, bordeaux. & $\begin{array}{l}\text { When the fruit is set, copper } \\
\text { sulphate. }\end{array}$ & $\begin{array}{l}\text { Repeat in } 2 \text { weeks if rot } \\
\text { appears, copper sulphate. }\end{array}$ \\
\hline Quince & Before buds open. & When fruit is set. & 2 weeks later. & 3 weeks later. \\
\hline $\begin{array}{l}\text { Raspberry } \\
\text { Blackberry, etc. }\end{array}$ & Before buds open, bordeaux. & $\begin{array}{l}\text { When new canes are a foot } \\
\text { high, bordeaux. }\end{array}$ & 2 weeks later, bordeaux. & \\
\hline Grape & $\begin{array}{c}\text { Before buds open copper } \\
\text { sulphate and paris green. }\end{array}$ & $\begin{array}{l}\text { When the leaves are half } \\
\text { grown, paris green. }\end{array}$ & $\begin{array}{l}\text { When the fruit is set, paris } \\
\text { green. }\end{array}$ & $\begin{array}{l}\text { Repeat in } 3 \text { weeks if neces- } \\
\text { sary, paris green. }\end{array}$ \\
\hline Gooseberry & As leaves open, bordeaux. & $\begin{array}{l}\text { Repeating in two weeks, } \\
\text { bordeaux. }\end{array}$ & 2 weeks later, bordeaux. & $\begin{array}{l}\text { Repeat in } 2 \text { weeks if neces- } \\
\text { sary, bordeaux. }\end{array}$ \\
\hline Currant & $\begin{array}{l}\text { As soon as worms are found } \\
\text { on lower and inner leaves, } \\
\text { bordeaux. }\end{array}$ & $\begin{array}{l}\text { If worms reappear, repeat in } \\
2 \text { weeks, bordeaux. }\end{array}$ & $\begin{array}{l}\text { Repeat in } 4 \text { weeks if neces- } \\
\text { sary, hellebore. }\end{array}$ & $\begin{array}{l}\text { After fruit is picked, bor- } \\
\text { deaux freely. }\end{array}$ \\
\hline$\overline{\text { Strawberry }}$ & $\begin{array}{l}\text { Just as the blossoms cpen, } \\
\text { bordeaux. }\end{array}$ & After fruit is set, bordeaux. & $\begin{array}{l}\text { As soon as berries are har- } \\
\text { vested, bordeaux. }\end{array}$ & \\
\hline
\end{tabular}

\section{Bordeaux Mixture}

Copper sulphate..............6 pounds

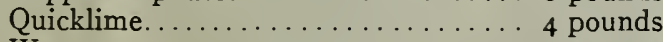

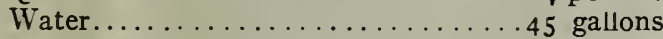

To destroy leaf-eating insects, add four ounces of paris green. For peach, use three pounds each of copper sulphate and lime, and three ounces of paris green, on account of tenderness.

We recommend crude petroleum, 20 to 25 per cent, with water, for apples, pears, plums, etc., and whale-oil soap, full strength and quantity, for peaches.

\section{Arsenate of Lead}

Arsenate of Lead, I lb.

\section{Hellebore}

Fresh White Hellebore, I oz.

Water, I 50 gallons.

Water, 3 gallons.

\section{Kerosene Emulsion}

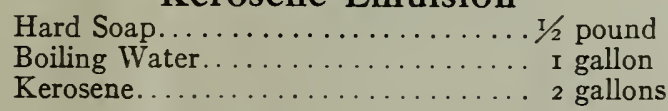

\section{Tobacco}

Boil Tobacco-stems, and use at the rate of two gallons to each pound of stems, for sucking insects.

\section{Copper Carbonate, 5 ounces. \\ Water, 50 gallons. \\ Ammonia, 2 quarts.}

The Copper Carbonate is best dissolved in large bottles, where it will keep indefinitely, as it should be diluted with water as required. For the same purpose as bordeaux.

Copper Sulphate, I pound. Water, 25 gallons.

This should be used only before the foliage appears. It is cacily applied, and acts as a general germicide and disinfectant. In simple solution copper sulphate is very injurious to foliage. When lime is added, as in making bordeaux mixture, its corrosive action is neutralized and injury to the foliage prevented. It adheres to the foliage better by the agency of lime.

\section{SUITABLE DISTANCES FOR PLANTING}

Apples, Standard.

Apple, Dwarf....

Pears, Standard.

Pears, Dwarf.

Peaches... ...

Nectarines and Apricots

Cherries, Sweet. . .
...30 to $40 \mathrm{ft}$. Cherries, Sour............ I5 to $18 \mathrm{ft}$. Raspberries, Black.

8 to ro ft. Plums................. 6 to $20 \mathrm{ft}$. Blackberries.

. I8 to $20 \mathrm{ft}$. Quinces.................. Io to $\mathbf{I} 2 \mathrm{ft}$. Strawberries, in rows

ro ft. Grapes.

. 6 to $18 \mathrm{ft}$. Currants.

. 6 to $18 \mathrm{ft}$. Gooseberries.

I8 to $20 \mathrm{ft}$. Raspberries, Red
8 to ro $\mathrm{ft}$. Strawberries, in beds.

- 3 to $4 \mathrm{ft}$. Asparagus, in beds.

3 to $4 \mathrm{ft}$. Asparagus, in field

3 to $4 \mathrm{ft}$.

\section{TABLE SHOWING THE NUMBER OF TREES OR PLANTS TO THE ACRE}

\begin{tabular}{|c|c|c|c|c|c|}
\hline I ft. & ar & ac & way & 43,560 & $8 \mathrm{ft}$. \\
\hline $2 \mathrm{ft}$. & & " & $66^{\circ}$ & I0,890 & $9 \mathrm{ft}$. \\
\hline $3 \mathrm{ft}$. & 6 & 68 & $" 6$ & 4,840 & ro $\mathrm{ft}$. \\
\hline $4 \mathrm{ft}$ & " & “ & $"$ & 2,722 & $12 \mathrm{ft}$. \\
\hline $5 \mathrm{ft}$. & " & 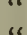 & 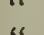 & $\mathrm{I}, 742$ & $14 \mathrm{ft}$. \\
\hline $\mathrm{ft}$. & “" & “ & ". & $\begin{array}{r}\text { I,2 IO } \\
888\end{array}$ & $\begin{array}{l}15 \mathrm{ft} . \\
16 \mathrm{ft} .\end{array}$ \\
\hline
\end{tabular}

$8 \mathrm{ft}$. apart each way

$9 \mathrm{ft}$.

$2 \mathrm{ft}$.

$4 \mathrm{ft}$.

88 I $6 \mathrm{ft}$.
.680 I8 ft. apart each way

$.53720 \mathrm{ft}$.

$.43525 \mathrm{ft}$.

$30230 \mathrm{ft}$.

$.22235 \mathrm{ft}$.

I93 $40 \mathrm{ft}$.

RULE.-Multiply the distance in feet between the rows by the distance the plants are apart in the rows, and the product will be the number of square feet for each plant or hill, which, divided into the number of feet in an acre $(43,560)$, will give the number to acre. 


\section{THE PROGRESS NURSERY COMPANY, TROY, OHIO}

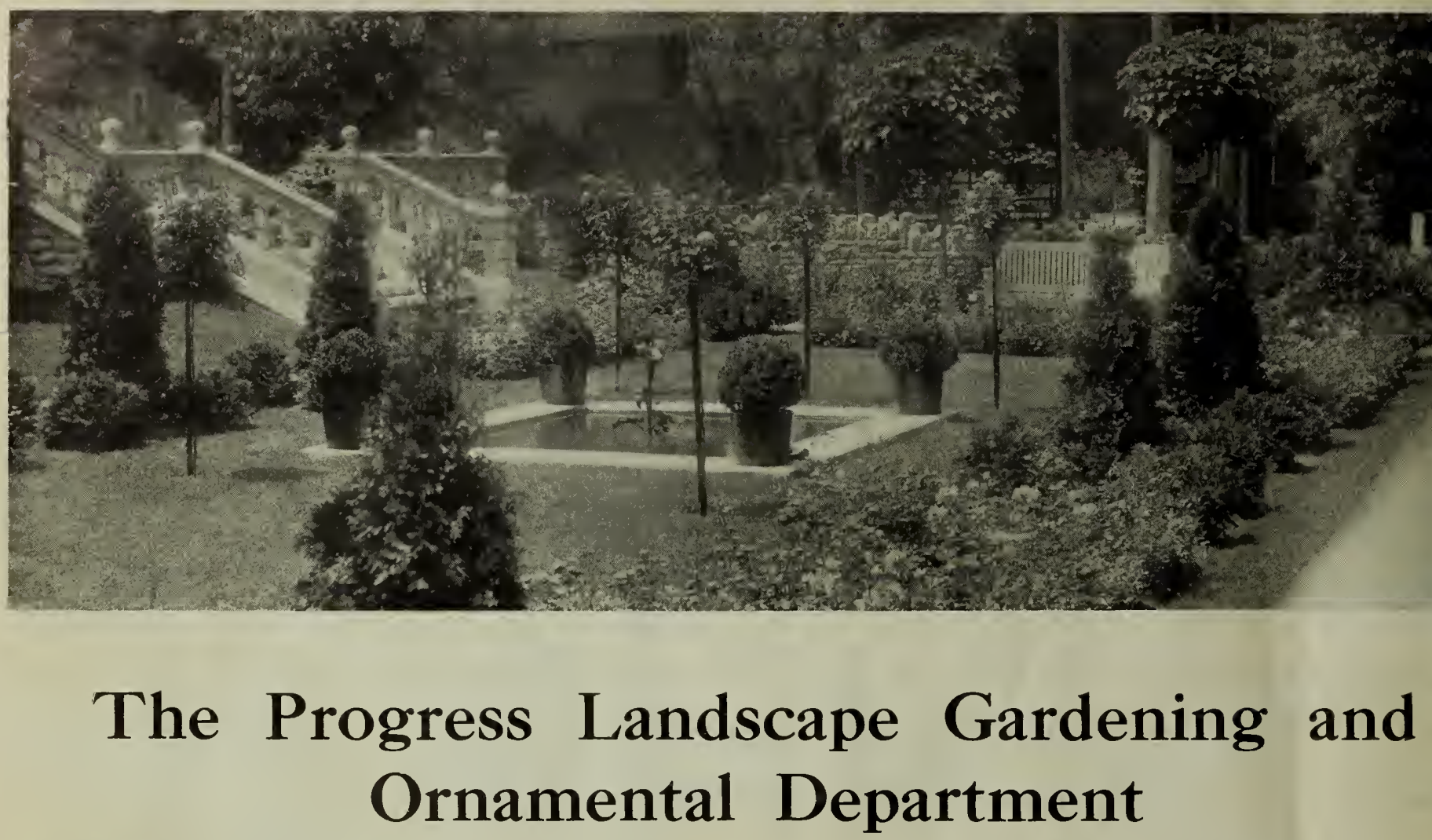

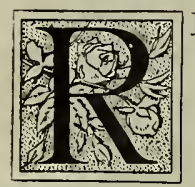

EALIZING the ever-increasing demand for ornamental trees, shrubbery, special plants and flowers, we have organized a Special Service Department to aid you in planning and planting.

Everybody likes to see beautiful trees, shrubbery and flowers growing about the home. Have you ever noticed a plain little vine-covered cottage, beautifully surrounded by trees, shrubbery and flowers?

The house seems to have grown there, and is really part of the landscape. Contrast this in your mind with the many homes you know of which lack this touch of nature to make them really home-like.
You have seen a beautiful open lawn, with shrubbery and flowers bordering its edges in irregular broken lines, the lawn surrounded in the same manner almost as if Mother Nature had planted it-there's nothing artificial looking about it. You have seen formal gardens, with their beautiful, foliage-lined walks, a lily-pond, mechanical terraces of velvety green, with ornamental plants set in regular fashion like so many jewels. It's all beautiful and adds hundreds of dollars to the value of the property, besides making the home attractive.

We are more than willing to assist you in making your home grounds attractive and beautiful. The service of this department is free to you.

\section{Our Special Offer}

If you will send us a rough plan of your yard, or grounds surrounding your home, showing location of house and all of the buildings, also any trees which might already be there, we will suggest a plan to you, free of charge, showing you how you may have flowers from early spring until late in the fall, and how you can make your yard and gardens beautiful the year round.

Remember, we give you this advice without any cost to you whatsoever. You are also under no obligation to us to buy.

In writing, describe fully the exact location of the house, indicating north and south, also the kind of soil you have.

The ornamental trees and shrubbery, vines and flowers, described in this catalogue are all healthy and hardy, and have the same careful inspection in shipping which we give our fruit trees.

\section{THE PROGRESS NURSERY COMPANY, L. G. DEPT., TROY, OHIO}




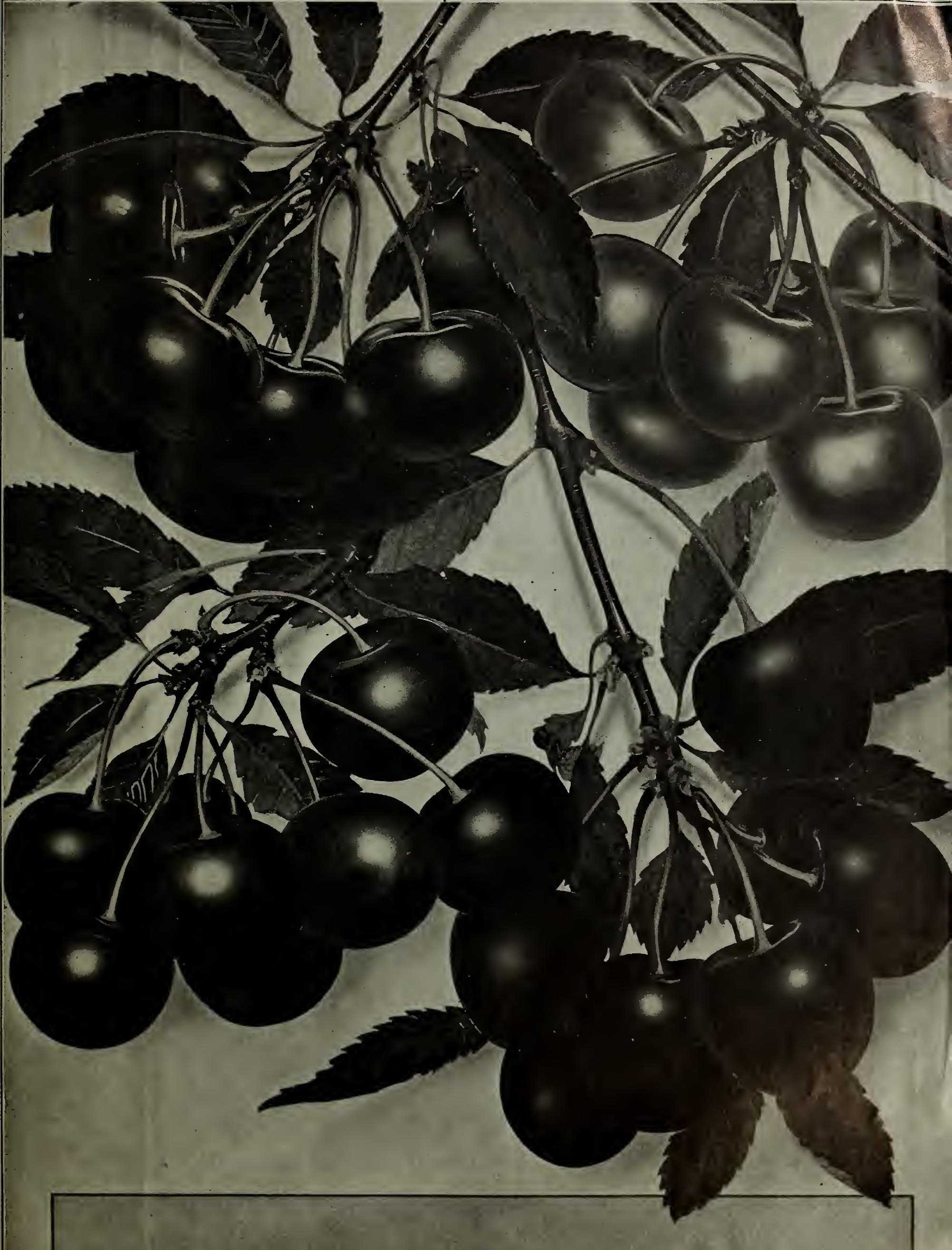




\section{THE PROGRESS IDEAL HOME ORCHARD}

Every home-owner should have a home orchard or garden.

The possibilities of the small fruit-garden are too often overlooked by those "who own city lots, suburban homes or even general farms. To most of these fruit is a luxury at its present city market prices.

Why not, with a very small investment and just a little extra work (which every person should enjoy), have a home garden, one that will prove a profitable investment as well as beautifying your home surroundings, thereby increasing its money value?

Here is a list of trees and plants on which we make you a special offer.

\section{Shipped Direct to You for Five Dollars}

53 of our BEST trees and plants selected with the idea of pleasing you and making you a permanent customer

\section{APPLES}

1 Yellow Transparent

1 Oldenburg

2 Northwestern Greening

1 Wealthy

2 York Imperial

2 Grimes Golden

1 Lowry

1 Bartlett

1 Flemish Beauty

1 Duchesse d'Angouleme

1 Sheldon

4 CHERRIES

1 Early Richmond

1 Montmorency

1 Dyehouse

1 Baldwin
10 PEACHES

2 Champion

2 Elberta

2 Late Crawford

2 Carman

2 Bokara

8 PLUMS

2 Lombard

2 Burbank

2 Bradshaw

2 Abundance

2 Concord Grape

2 Wilder Currant

2 Downing Gooseberry

10 Conover's Colossal Asparagus

1 Hydrangea

All the trees of our Ideal Orchard are of our regular orchard size and first-class in every respect. You cannot realize a larger return from the expenditure of a $\$ 5$ bill and a little of your time than in investing in this orchard, which will more than supply your table with the best of fruits throughout the year.

ONLY ONE ORDER SHIPPED TO ANY PERSON

The Progress Nursery Company . . Troy, Ohio 